\title{
Palynological Characters and Their Phylogenetic Signal in Rubiaceae
}

\author{
Steven Dessein, ${ }^{1,3}$ Helga Ochoterena, ${ }^{2}$ Petra De Block,,${ }^{3}$ Frederic Lens, ${ }^{1}$ \\ Elmar Robbrecht, ${ }^{3}$ Peter Schols, ${ }^{1}$ Erik Smets, ${ }^{1}$ Stefan Vinckier, ${ }^{1}$ \\ and Suzy HuYsmans ${ }^{1}$ \\ ${ }^{1}$ Laboratory of Plant Systematics, Institute of Botany and Microbiology \\ Catholic University of Leuven \\ Kasteelpark Arenberg 31, B-3001 Leuven, Belgium \\ ${ }^{2}$ Instituto de Biología \\ Universidad Nacional Autónoma de México \\ Apdo. Postal 70-367, CP 04510, Mexico City, Mexico \\ ${ }^{3}$ National Botanic Garden of Belgium \\ Domein van Bouchout, B-1860 Meise, Belgium
}

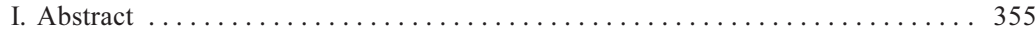

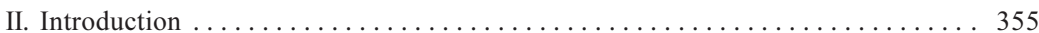

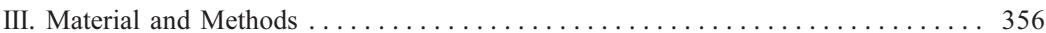

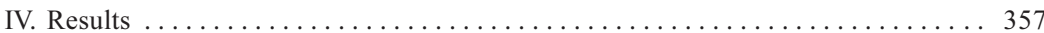

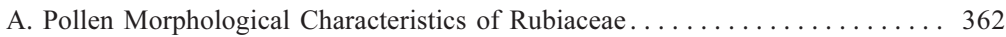

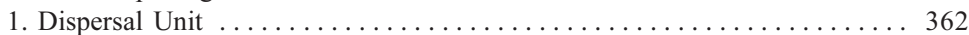

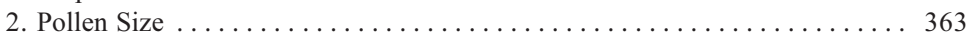

3. Pollen Shape ............................. 365

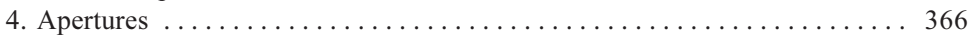

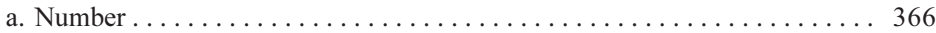

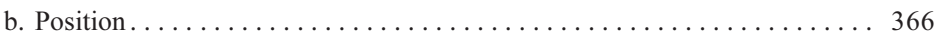

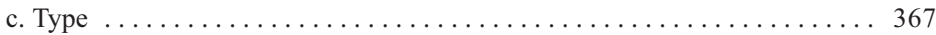

d. Protruding Onci and Pollen Buds .................. 371

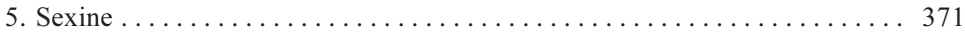

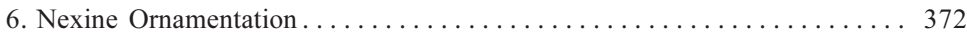

7. Stratification of the Pollen Wall .................... 373

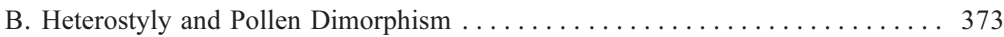

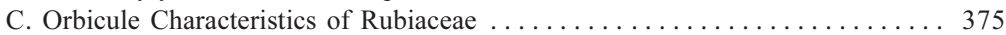

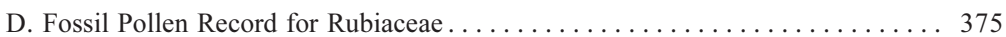

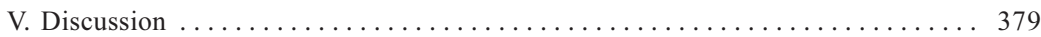

A. Systematic Significance of Pollen Morphology in Rubiaceae . . . . . . . . . . 379

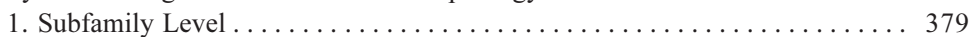

2. Tribal Level $\ldots \ldots \ldots \ldots \ldots \ldots \ldots \ldots \ldots \ldots \ldots \ldots \ldots \ldots \ldots \ldots$

Copies of this issue [71(3)] may be purchased from The NYBG Press, The New York Botanical Garden, Bronx, NY 10458-5126, U.S.A.; nybgpress@nybg.org. Please inquire as to prices. 


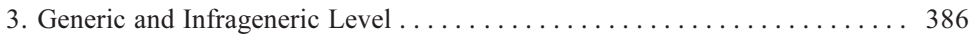

a. Generic Level ................................ 386

b. Subgeneric and Specific Level ...................... 386

c. Infraspecific Variation ........................... 387

B. Systematic Value of Pollen Data Compared with Other Morphological Characters 387

C. Orbicules and Phylogeny ............................... 388

D. Coding Pollen Characters for Cladistic Analyses ................ 388

VI. Future Research . . . . . . . . . . . . . . . . . . . . . . . . . . . . 391

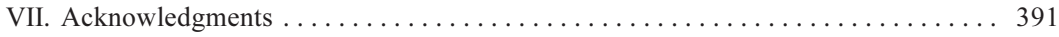

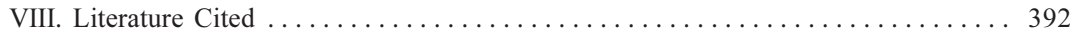

IX. Appendix 1: Template for Pollen Descriptions ................... 401

X. Appendix 2: List of Genera in the Pollen Database, with Reference to the Literature 401

XI. Appendix 3: List of Genera according to Tribes ................... 412

\section{Abstract}

In the 1990s Rubiaceae became a hot spot for systematists, mainly due to the comprehensive treatment of the family by Robbrecht in 1988. Next to the exploration of macromolecular characters to infer the phylogeny, the palynology of Rubiaceae finally received the attention it deserves. This article aims to present a state-of-the-art analysis of the systematic palynology of the family. The range of variation in pollen morphology is wide, and some of the pollen features are not known from other angiosperm taxa; e.g., a looplike or spiral pattern for the position of apertures in pantoaperturate grains. We compiled an online database at the generic level for the major pollen characters and orbicule presence in Rubiaceae. An overview of the variation is presented here and illustrated per character: dispersal unit, pollen size and shape, aperture number, position and type, sexine ornamentation, nexine pattern, and stratification of the sporoderm. The presence/absence and morphological variation of orbicules at the generic level is provided as well. The systematic usefulness of pollen morphology in Rubiaceae is discussed at the (sub)family, tribal, generic, and infraspecific levels, using up-to-date evolutionary hypotheses for the different lineages in the family. The problems and opportunities of coding pollen characters for cladistic analyses are also treated.

\section{Introduction}

The predominantly tropical family Rubiaceae includes approximately 12,000 species in 650 genera (Delprete, 1999a), making it one of the five largest families of flowering plants. The publication of Robbrecht's Tropical Woody Rubiaceae (1988a) boosted systematic interest in the family by providing a synthesis of the available morphological data and a comprehensive, worldwide classification system. Since then, many investigators have concentrated their research efforts on Rubiaceae, and a considerable amount of new morphological and molecular data have become available. Mainly due to the advance of molecular systematics, unexpected relationships were often suggested, and the infrafamily classification has changed dramatically to translate the new insights. One of the four subfamilies recognized by Robbrecht (1988a, 1993) - i.e., Antirheoideae - collapsed, and many tribes were redefined (e.g., Isertieae, Naucleeae, Spermacoceae). This process of refining our knowledge of the evolutionary history of Rubiaceae is constantly assisted by morphological observations and continues to date, resulting in shifting genera and tribes, in redelimitation of genera, and in description of new taxa.

Pollen morphological data have proved to be particularly informative in elucidating evolutionary relationships within Rubiaceae. Erdtman's (1952, reprinted in 1971) comparative pollen study of 230 species in 120 genera of Rubiaceae reflected some of the variation. Bremekamp 
(1952), however, was the pioneer in using pollen characters at a large scale to infer the phylogeny of the family. This is not surprising, because he was also a student of the eurypalynous family Acantaceae, in which he used pollen features to clarify many difficult issues, such as the relationship between Acanthopale C. B. Clarke and Dischistocalyx T. Anders ex Benth., to cite one. Subsequent studies dealing with the systematics of the family often included pollen morphological evidence to support or reject taxonomic decisions (e.g., Bremekamp, 1966; Lewis, 1965a, 1965b; Verdcourt, 1958). Since then, several taxonomists have documented the pollen morphology of their study group, and a few palynological articles have been published at the tribal level, e.g., Morindeae (Johansson, 1987a), Gardenieae (Persson, 1993).

In spite of these efforts, Rubiaceae remained one of the blank spots on the pollen morphological map of flowering plants (Muller, 1981). In the last two decades, however, the input of new observations increased. These new pollen data are scattered over systematic and palynological journals and are often difficult to compare. Moreover, some contributions are not widely accessible, because they are part of unpublished theses (e.g., Es, 1999; Vanthournout, 2002). Because a new synthesis of the pollen morphological knowledge of Rubiaceae was also badly needed, we compiled a database at the Laboratory of Plant Systematics (Catholic University of Leuven), containing key pollen features of Rubiaceae genera with reference to relevant literature. In the present article we portray and discuss the known variation of the main pollen characters. Gaps in our pollen knowledge are localized, and features that deserve more attention are pinpointed. We critically discuss coding issues and measure the power of the phylogenetic signal by evaluating the data on up-to-date evolutionary hypotheses. We also hope that this article will encourage further palynological research in the family and enhance the use of pollen data in phylogenetic analyses.

\section{Material and Methods}

In order to synthesize the pollen morphology of Rubiaceae, we gathered all of the literature listed in the Seventh Bibliographic Index to the Pollen Morphology of Angiosperms (Tissot \& van der Ham, 1994) and added all modern literature. For each genus, we retained the most recent or the most reliable and relevant pollen morphological works. From these, after checking all taxa against the most recent classifications, we distilled the pollen morphological characters at the generic level and stored them in a database with reference to the literature consulted. The pollen database is linked to a systematic database holding basic information such as species number, distribution, and the systematic position of each genus. The database is available online at $<$ http://www.kuleuven.ac.be/bio/sys/pollen $>$. The quality requirements for the works retained were set as follows: (1) Clear illustrations (preferably SEM and LM photographs) are present; (2) the authors have reliable taxonomic knowledge of the species investigated; (3) pollen descriptions are present or, if not, the main pollen characters can be deduced from the illustrations. Geographically oriented palynological contributions (e.g., pollen floras) or general works on Rubiaceae with scanty notes on pollen morphology were therefore often omitted, but reference to them is made in the database. Genera for which pollen data found in literature do not fulfill the quality requirements set above are present in the database, but they are not used to prepare the pollen description of the tribes to which they belong.

In some cases, how to convert the raw data in an article into pollen features for genera was not evident, especially when the results section was limited to the descriptions of pollen types and no species or generic pollen data were provided. In order to avoid these problems and to facilitate the exchange of pollen data among scientists, we propose a pollen description template for Rubiaceae in Appendix 1. 
Table I summarizes the pollen data at the tribal level. Exceptional observations are not taken into account in the table, but they can be found in the pollen database. All genera included in the database with reference to the pollen works used are listed in Appendix 2. The tribal position of the genera is given in Appendix 3.

The phylogenetic value of pollen characters at the tribal level is evaluated on the basis of a summary cladogram reflecting the currently accepted relationships in Rubiaceae. This tree is constructed with MacClade, and the backbone is based on the study by Bremer et al. (1999: $r b c \mathrm{~L}, n d h \mathrm{~F})$. In this study, three subfamilies were recognized: Rubioideae, Cinchonoideae, and Ixoroideae. Later in this article we use Cinchonoideae s.str. and Ixoroideae s.l., because these two subfamilies were respectively reduced and enlarged vis-à-vis Robbrecht's (1988a, 1993) earlier concepts with the same name. Relationships within the three subfamilies as drawn in the summary cladogram are based on the following articles: Andersson and Rova (1999: rps 16intron), Bremer and Manen (2000: $r b c \mathrm{~L}, a t p \mathrm{~B}, r b c \mathrm{~L}, r p s$ 16-intron), Piesschaert et al. (2000a: rps 16-intron), and Dessein (2003: rps 16-intron; ITS) for the Rubioideae; Rova (1999: $\operatorname{trn} \mathrm{L}-\mathrm{F}$, trnL-F spacer, rps 16-intron), Razafimandimbison and Bremer (2001: ITS, $r b c \mathrm{~L}$, $t r n \mathrm{~T}-\mathrm{F}$ ), Rova et al. (2002: $\operatorname{trn} \mathrm{L}-\mathrm{F}$ ) for the Cinchonoideae s.str.; and Rova (1999: $\operatorname{trn} \mathrm{L}-\mathrm{F}$, $\operatorname{trn} \mathrm{L}-\mathrm{F}$ spacer, rps 16-intron), Bremer and Thulin (1998: $r b c \mathrm{~L}$ ), Andreasen et al. (1999: ITS, $r b c \mathrm{~L})$, Andreasen and Bremer (2000: ITS, $r b c \mathrm{~L}$ ), Dessein et al. (2001b: rps16-intron, $r b c \mathrm{~L}$ ), and Rova et al. (2002: $\operatorname{trn} \mathrm{L}-\mathrm{F}$ ) for the Ixoroideae s.l.

Terminology follows, unless stated otherwise, the online edition of Punt et al. (1994) at $<$ http://www.bio.uu.nl/ palaeo/glossary/index.htm $>$. For shape classes $(\mathrm{P} / \mathrm{E})$ we adopted the wide definitions of Nilsson and Praglowski (1992); that is, oblate (0.50-0.75), suboblate (0.75$0.88)$, spheroidal (0.88-1.14), subprolate (1.14-1.33), and prolate (1.33-2.00).

\section{Results}

Our literature review resulted in 486 pollen morphologically documented genera, which represent about $75 \%$ of the total number of estimated rubiaceous genera (Appendix 2). For 423 genera $(65 \%)$, pollen data were reliable enough to be included in this article, the following genera being excluded: Antirhea Comm. ex Juss., Amaracarpus Blume, Aulacocalyx Hook. f., Bobea Gaudich., Bouvardia Salisb., Callipeltis Stev., Calycosia A. Gray, Canephora Juss., Ceuthocarpus Aiello, Chapeliera A. Rich., Coccochondra P. Br., Cosmocalyx Standl., Craterispermum Benth., Cremaspora Benth., Cubanola Aiello, Deppea Cham. \& Schltdl. Didymaea Hook. f., Dolichometra K. Schum., Duidania Standl., Feretia Delile, Fernelia Comm. ex Lam., Flagenium Baill., Galiniera Delile, Gallienia Dubard \& Dop, Gillespiea A. C. Sm., Heinsenia K. Schum., Heterophyllaea Hook. f., Hydnophytum Jack, Hypobathrum Blume, Hyptianthera Wight \& Arn., Kraussia Harv., Machaonia Humb. \& Bonpl., Morindopsis Hook. f., Nesohedyotis (Hook. f.) Bremek., Oreopolus Schltdl., Paraknoxia Bremek., Pentaloncha Hook. f., Pentanopsis Rendle, Phitopis Hook. f., Phuopsis (Griseb.) Hook. f., Pittoniotis Griseb., Placopoda Balf. f., Pouchetia A. Rich., Psathura Comm. ex Juss., Pseudonesohedyotis Tennant, Rachicallis DC., Readea Gillespie, Rhopalobrachium Schltr. \& K. Krause, Robynsia Hutch., Sarcopygme Setchell \& Christoph., Schmidtottia Urb., Siemensia Urb., Spiradiclis Blume, Steenisia Bakh. f., Stenostomum C. F.Gaertn., Streblosa Korth., Striolaria Ducke, Tamridaea Thulin \& B. Bremer, Temnocalyx Robyns, Thecorchus Bremek., Thogsennia Aiello, Urophyllum Jack ex Wal., Warszewiczia Klotzsch, Zuccarinia Blume. For 94 genera (14\%), data on orbicules were found. The pollen documentation for most genera is far from complete, which is illustrated by the fact that only an estimated $15 \%$ of all Rubiaceae species have been investigated. Moreover, in some writings pollen descriptions are concise or incomplete. Conflicts between pollen data found in 


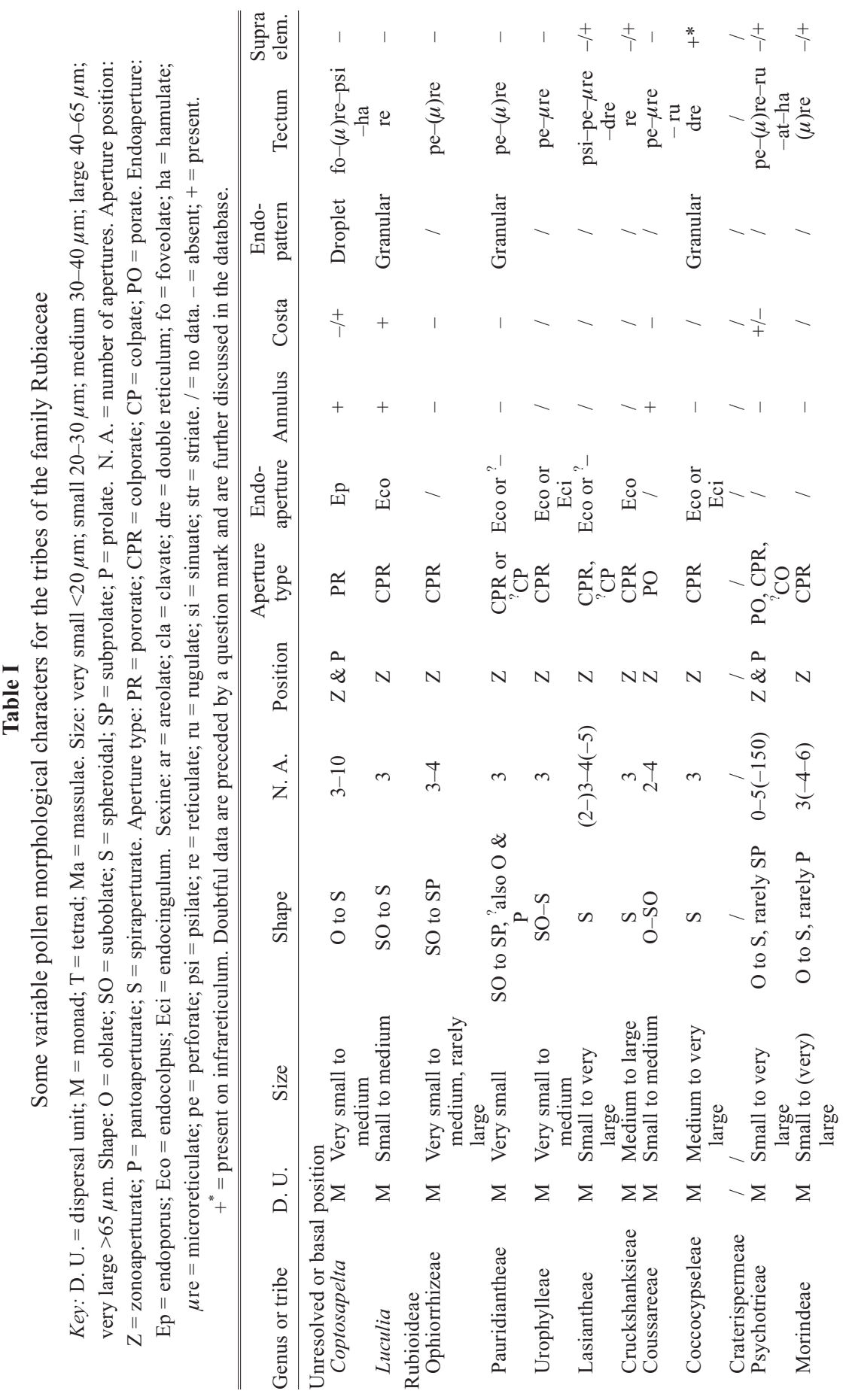




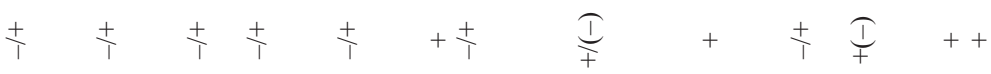

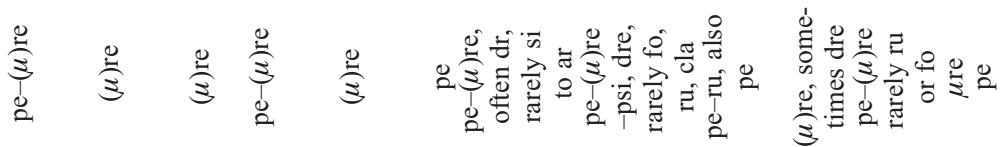

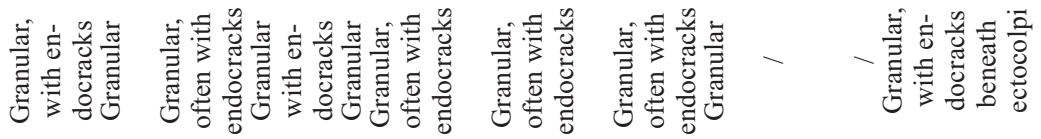

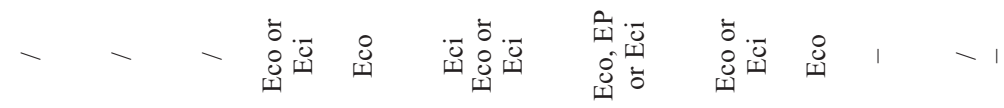

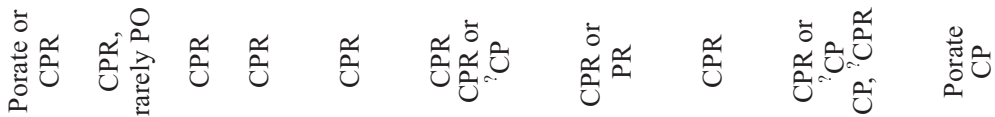

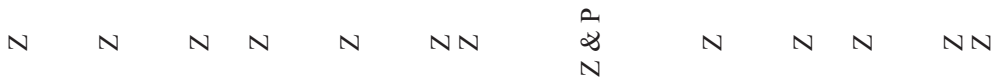

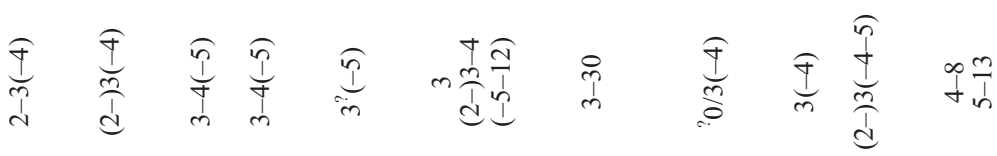

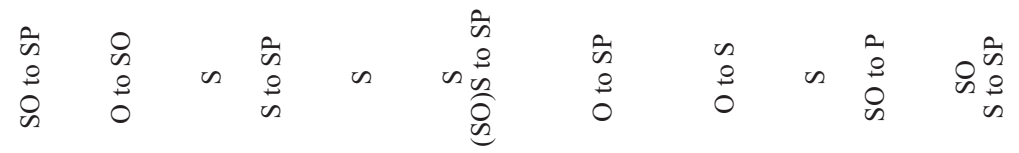

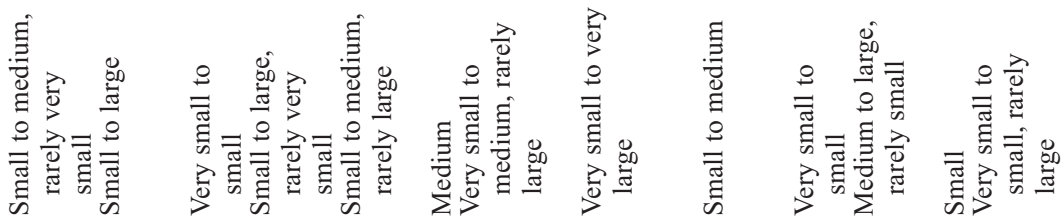

$\Sigma \Sigma \Sigma \Sigma \Sigma \Sigma \Sigma \Sigma \Sigma \Sigma \Sigma \Sigma \Sigma \Sigma \Sigma \Sigma \Sigma$

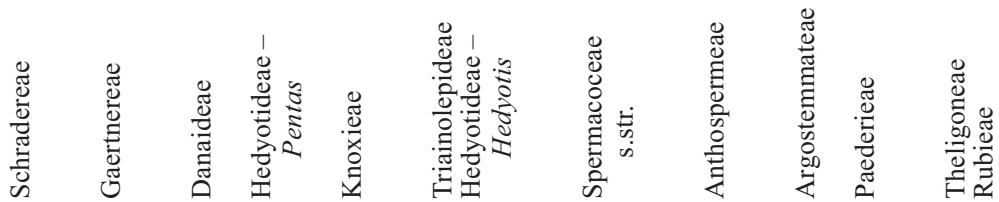




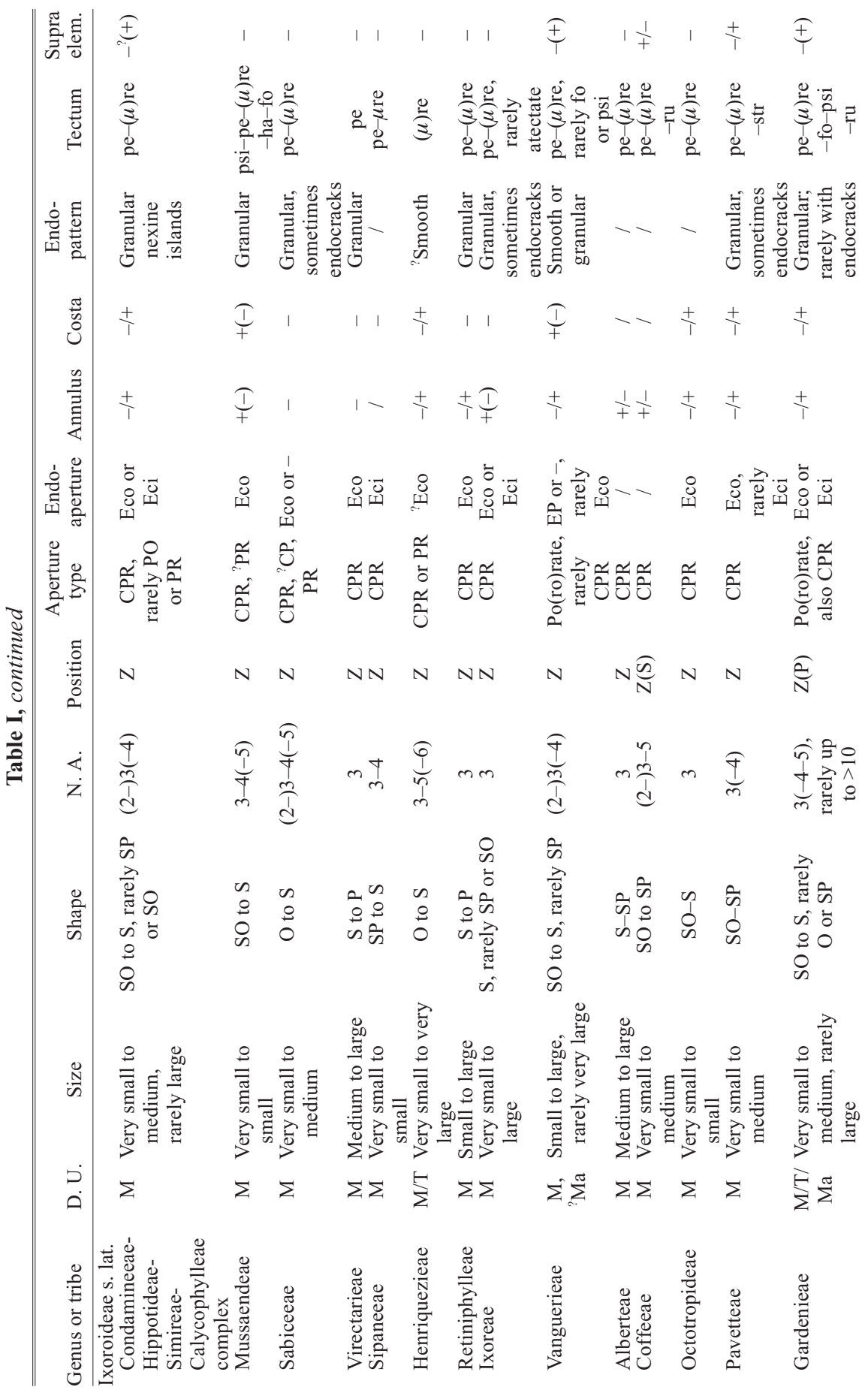




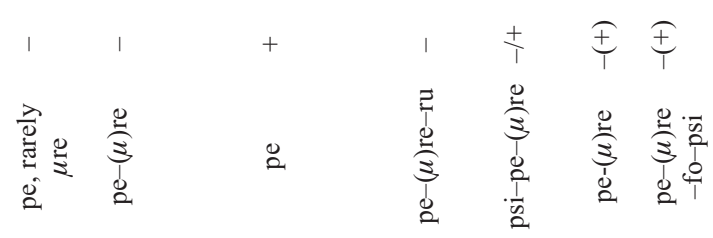

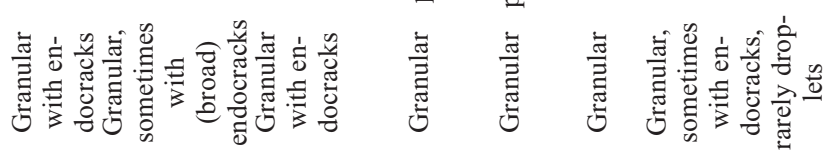
$+\quad+\frac{1}{+}$

$+\quad+\quad+$

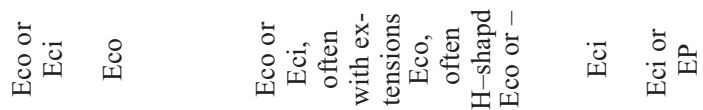

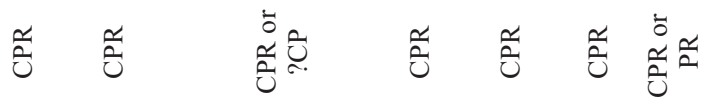

$\begin{array}{lllllllllllll}N & N & N & N & N & \end{array}$

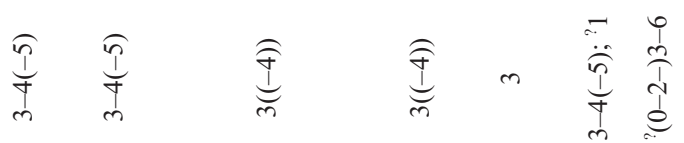

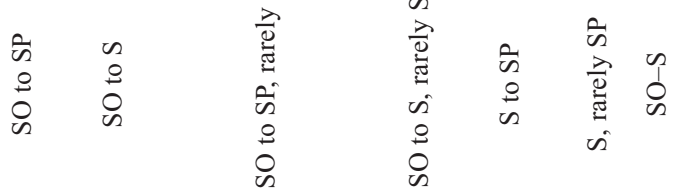

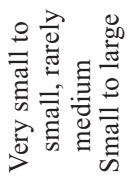

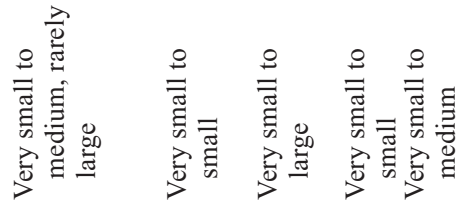

$\Sigma \Sigma \Sigma \Sigma \Sigma \Sigma \Sigma$

落

$\dot{m}$

芩

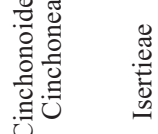

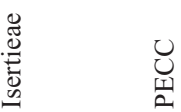

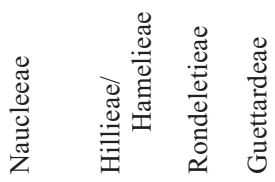



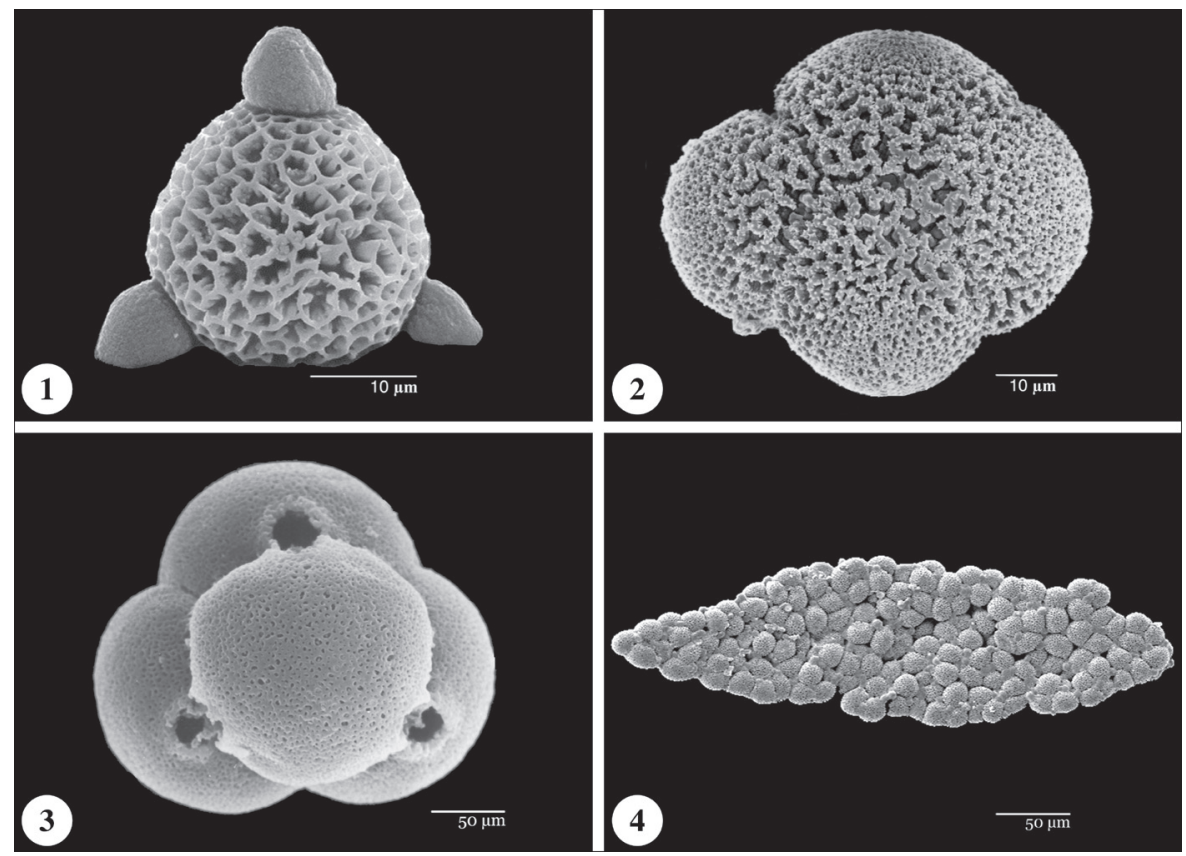

Figs. 1-4. Types of pollen dispersal. 1. Monad of Psydrax subcordata (DC.) Bridson, unacetolyzed (F. Lens, unpubl. data). 2. Tetrahedral tetrad with opposite apertures of Ganguelia gossweileri (S. Moore) Robbr. (Robbrecht et al., 1996). 3. Uniplanar, rhomboidal tetrad of Euclinia longiflora Salisb. (S. Huysmans, unpubl. data). 4. Pollen arranged in massulae, as observed in Massularia acuminata (G. Don) Bullock ex Hoyle, unacetolyzed (P. De Block \& M. Verhaegen, unpubl. data).

different publications were sporadically noticed and mainly concerned shape in equatorial view and size. Differences in use of pollen terminology also remain an obstacle for a correct interpretation of the observations. We want to stress again the benefits of the general use of the international glossary by Punt et al. (1994).

\section{A. POLLEN MORPHOLOGICAL CHARACTERISTICS OF RUBIACEAE}

\section{Dispersal Unit}

Rubiaceae pollen grains are generally dispersed as monads (Fig. 1), but permanent tetrads (Figs. 2-3) are present in 13, mainly African, genera of Gardenieae (Robbrecht, 1988a) and in the distant genus Gleasonia Standl. in Henriquezieae (Rogers, 1984). Randia L. is the only genus known with both monads and tetrads (Persson, 1993), but the generic boundary of this genus is in flux (Gustafsson \& Persson, 2002). The occasional presence of tetrads in Lasianthus W. Jack as reported by Huang (1972) needs confirmation. Massulae, pollen agglutinated in larger bodies of a few hundred grains and dispersed as a unit (Fig. 4), occur in a single genus of Gardenieae, Massularia K. Schum. (Persson, 1993). The observations by Igersheim (1989) of massulae in a few Psydrax Gaertn. and Keetia E. Philips species need confirmation.

The configuration of the permanent tetrads is sometimes variable. Ganguelia Robbr., for instance, shows $30 \%$ decussate and $70 \%$ tetrahedral tetrads in the same specimen; a single rhomboidal uniplanar tetrad has also been observed in that genus (Robbrecht et al., 1996). 


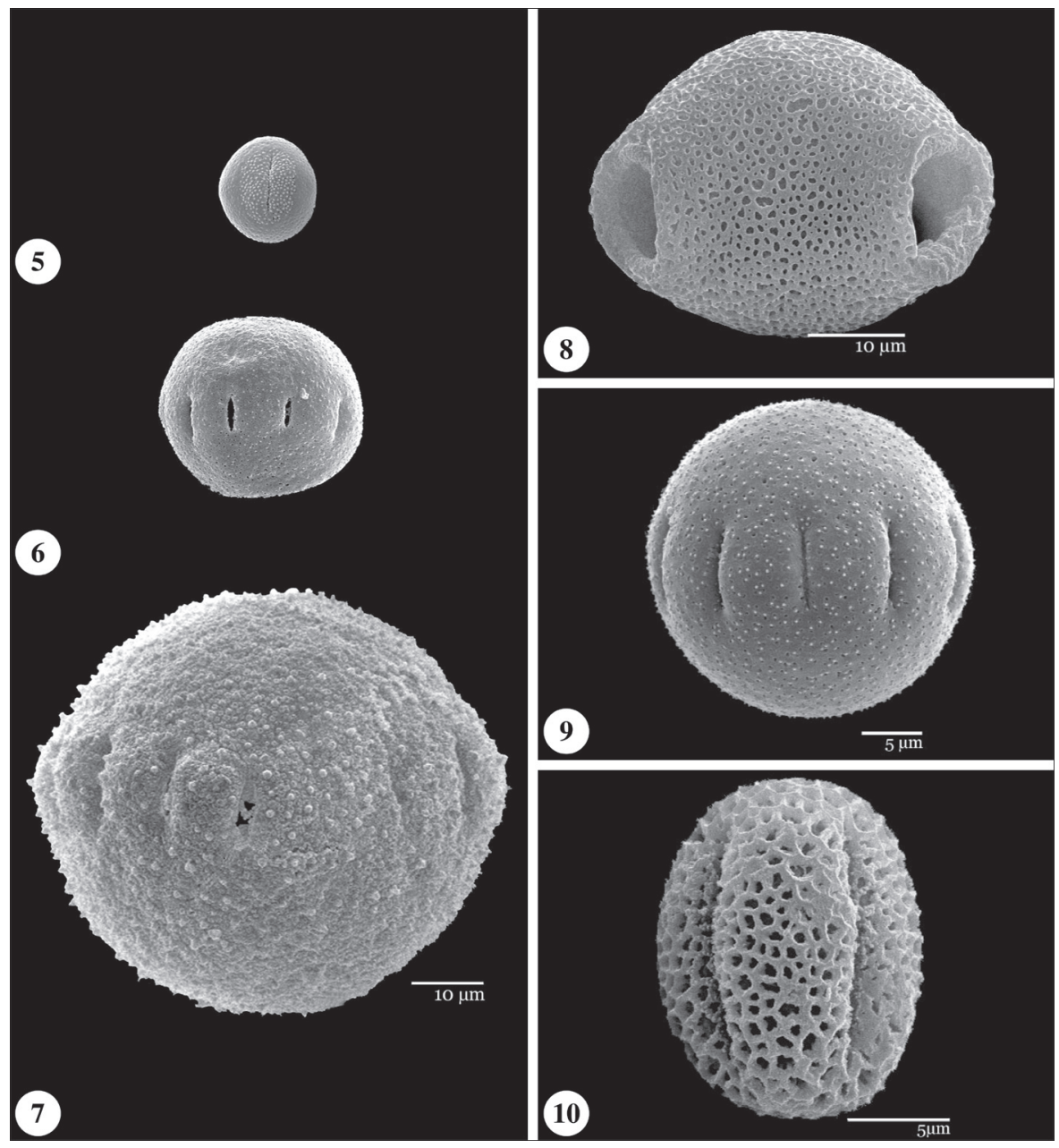

Figs. 5-10. Pollen shape and size. 5. Spermacoce natalensis: pollen size 14-19 $\mu \mathrm{m}$ (Dessein et al., 2002a). 6. Spermacoce chaetocephala DC.: pollen size 38-52 $\mu \mathrm{m}$ (Dessein et al., 2002a). 7. Spermacoce ivorensis Govaerts: pollen size 105-125 $\mu \mathrm{m}$ (Dessein et al., 2002a). 8. Equatorial view of an oblate pollen grain of Psydrax horizontalis (K. Schum. \& Thonn.) Bridson (Lens et al., 2000). 9. Equatorial view of a spheroidal pollen grain of Crusea calocephala DC. (Dessein, 2003). 10. Equatorial view of a prolate pollen grain of Kohautia grandiflora DC. (S. Dessein, unpubl. data).

Persson (1993) described tetrads of 11 genera from the Gardenieae, but he gave no detailed information about configuration; all tetrads shown by him are tetrahedral.

\section{Pollen Size}

Pollen size after acetolysis (Figs. 5-7) ranges from $6 \mu \mathrm{m}$ in Danais cernua Baker (Huysmans, 1998) to $133 \mu \mathrm{m}$ in Diodella teres Small (Dessein, 2003). The majority of species have pollen grains in the $20-40 \mu \mathrm{m}$ range. Wodehouse (1935) showed that pollen grains within this size 

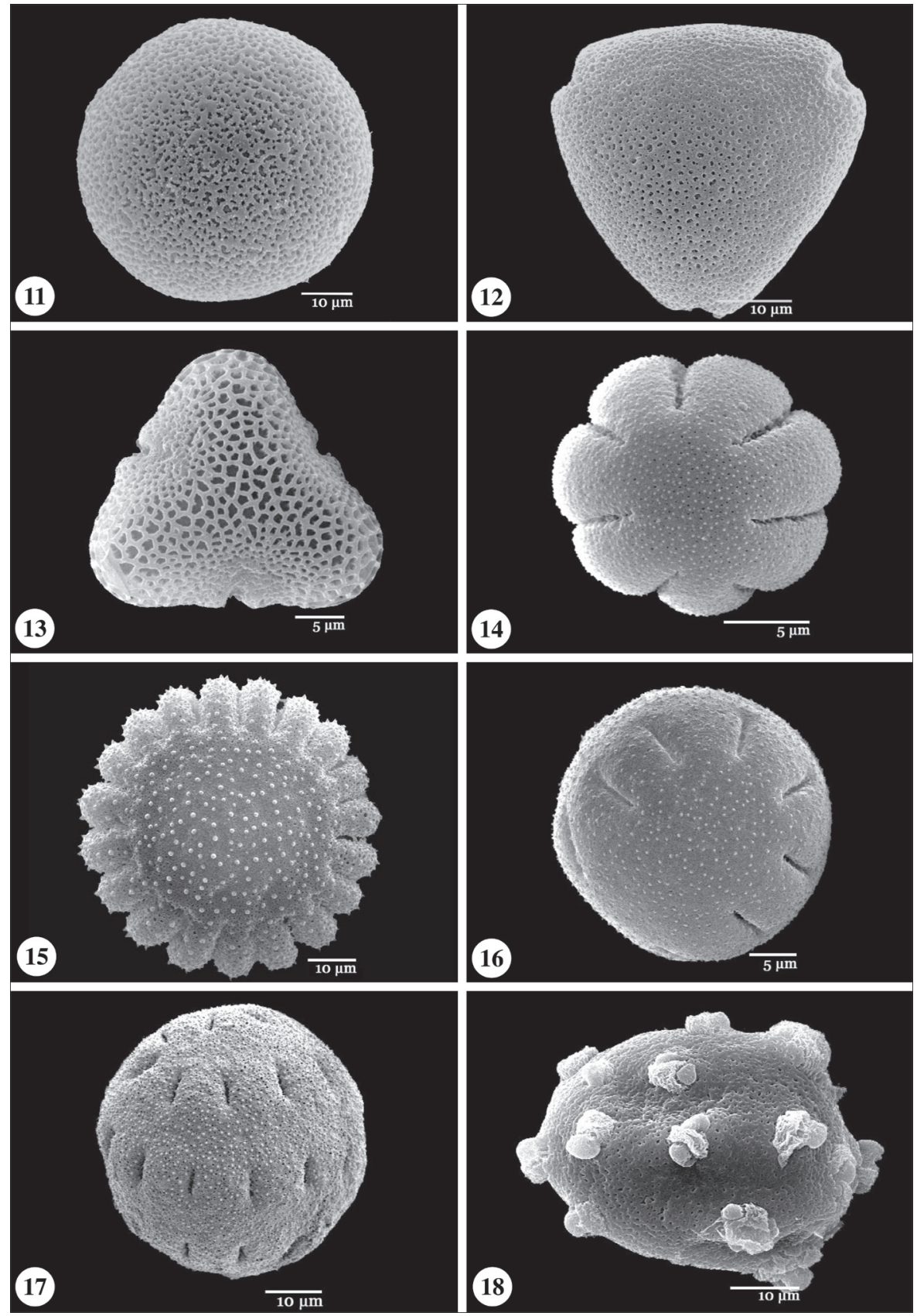

Figs. 11-18. Number of apertures and aperture position. 11. Polar view of a circular, inaperturate pollen grain of Palicourea petiolaris H. B. \& K. (F. Piesschaert, unpubl. data). 12. Polar view of a triangular, 3-colporate pollen grain of Tapiphyllum cinerascens Robyns, with apertures situated at the angles (Lens et al., 2000). 13. Polar view of a triangular 3-colporate pollen grain of Spermacoce stenophylla, 
range are ideally adapted to be released from the anthers, transported by moderate winds, and attached to insect vectors and to stigmata. Observation of very large or very small pollen grains may therefore also point to specific pollination syndromes.

Although pollen size is often stable at the species level, we occasionally noticed a considerable intraspecific size variation (e.g., the equatorial diameter (E) varies from 19 to 41 in Spermacoce fabiformis Harwood). Sometimes this variation can be explained in terms of infraspecific taxa (e.g., Dessein et al., 2002a), polyploidy (e.g., Puff, 1986a), growth conditions, flower/anther size (e.g., Puff, 1986a), or heterostyly (see the section on "Heterostyly and Pollen Dimorphism" below). More often, the variation is difficult to interpret. In Spermacoce fabiformis, for example, individuals with larger pollen are often found in drier areas, exactly the opposite of what one would readily expect (Dessein et al., 2005b). Even within one individual, size variation can be considerable. In Hedythyrsus thamnoideus (K. Schum.) Bremek., the polar axis (P) varies from 14 to $30 \mu \mathrm{m}$ in the same specimen, whereas in all species of the genus Ernodea Sw. two size classes of pollen were observed in one anther (Negrón-Ortiz, 1996). Negrón-Ortiz figured out that in Ernodea large pollen grains are more abundant than are small pollen grains and that viability is associated with the larger grains. Two size ranges were also found in pollen of Hintonia latiflora (DC.) Bullock, where it seems to be correlated with differences in exine thickness (Ochoterena, 2000); in the latter case nothing is known about the viability of the pollen grains. Whether size dimorphism is a general feature of Rubiaceae pollen is unclear at present. Mathew and Philip (1983) listed 35 taxa in which they found significant size differences, but they did not state whether this variation was observed within one specimen or several specimens of one taxon.

At the family level, there is no correlation between flower size and pollen size. Within certain lineages, however, this correlation has been observed (Dessein et al., 2002a; Rogers, 1984).

The fact that pollen size may be variable within a single species, together with the strong influence of preparation and observation techniques on size and shape of pollen grains (see Reitsma, 1969), makes comparisons of size measurements across different publications tricky. Nevertheless, in our opinion, pollen size can be a marker distinguishing related genera or characterizing some tribes. The Rubieae and Naucleeae s.l., for example, have predominantly very small to small pollen grains $(<30 \mu \mathrm{m})$, whereas Palicourea Aubl. differs from most other Psychotrieae in having very large pollen grains $(65-125 \mu \mathrm{m})$. In eurypalynous groups such as the Spermacoceae s.str., however, pollen size is useful only at the species level (Dessein, 2003).

\section{Pollen Shape}

Pollen shape of hydrated grains in equatorial view (P/E) ranges from oblate (Fig. 8) to prolate (Fig. 10) but is most often spheroidal (Fig. 9). The outline of hydrated pollen grains in polar view (amb) is mostly circular (Fig. 11), often slightly lobed due to sunken colpi (Figs. 14-15). In a few species, such as Dictyandra arborescens Welw. ex Hook. f., a quadrangular shape is typical (Robbrecht, 1984), whereas triangular shapes (Figs. 12-13) are observed in, for example, the genera Tapiphyllum Robyns and Psydrax Gaertn. (Lens et al., 2000).

Figs. 11-18, continued

with apertures in the middle of the sides (Dessein et al., 2005b). 14. Polar view of a 7-colpate grain of Galium mollugo L. (S. Huysmans, unpubl. data). 15. Polar view of a 19-colporate pollen grain of Spermacoce dibrachiata Oliv.; notice the slightly lobed outline due to sunken colpi (Dessein et al., 2002a). 16. A pantoaperturate pollen grain of Spermacoce octodon, with the colpi arranged in a looplike pattern similar to the line on a tennis ball (Dessein et al., 2002a). 17. A pantoaperturate pollen grain of Spermacoce thymoidea, with three parallel rows of colpi (Dessein et al., 2002a). 18. A pantoporate grain of Geophila repens (K. Es, unpubl. data). 
The shape of the grains depends heavily on harmomegathic effects: Dehydration often leads to more prolate pollen by invagination of the ectocolpi. The systematic value of shape characters is questionable in Rubiaceae, but, for instance, in Spermacoce stenophylla F. Muell. and $S$. inaperta F. Muell., pollen is characteristically oblate and triangular in polar view (Dessein et al., 2005b).

\section{Apertures}

\section{a. Number}

Triaperturate pollen grains are most common in Rubiaceae and exhibit the plesiomorphic condition in the family (Figs. 12-13). In numerous genera, tetraaperturate and, more rarely, pentaaperturate pollen grains are found in addition to the triaperturate ones. In the more derived herbaceous groups, Spermacoceae s.str. and Rubieae, pluriaperturate grains are the rule (Figs. 14-17). In Spermacoceae s.str. the number of apertures varies between 3 and 30 (Dessein et al., 2003), whereas the maximum number so far observed in Rubieae is 13 (Huysmans et al., 2003). Pluriaperturate pollen grains are also sporadically observed in a few species or genera of other tribes, such as Theligoneae (Theligonum L.), Spermacoceae s.l. (Gomphocalyx Baker, Kohautia Cham. \& Schltdl., Neanotis W. H. Lewis, Phylohydrax Puff), and Gardenieae (Rosenbergiodendron Fagerl. and Randia). In the paleotropical specimens of Geophila repens (L.) Johnst., the apertures are as numerous as 150 (Vanthournout, 2002).

In some species of Antirhea (Chaw \& Darwin, 1992), Chassalia Comm. ex Juss. (Piesschaert et al., 1999a), Nertera Banks \& Sol. ex Gaertn. (Robbrecht, 1982b), Palicourea Aubl. (Robbrecht, 1988a), Psychotria L. (Johansson, 1992), and Rudgea Salisb. (Jung-Mendaçolli, 1984; Piesschaert, unpubl.), apertures seem to be absent (Fig. 11). It is unclear whether this pollen is really inaperturate or rather omniaperturate. In the heterostylous species of Hymenocoleus Robbr., brevistylous flowers seem to produce nonaperturate pollen grains, whereas longistylous flowers produce 3-5-porate pollen grains (Robbrecht, 1977). Biaperturate pollen grains are reported in 16 genera, including Aidia Lour. (Puttock, 1992), Atractocarpus Schltr. \& K. Krause (Puttock, 1992), Coussarea Aubl. (Jung-Mendaçolli, 1984), Myrmecodia Jack (Robbrecht, 1988a), and Schradera Vahl (Puff et al., 1993a). Only for the monospecific genus Leucocodon Gardner might it serve as a diagnostic character (Puff \& Buchner, 1998); in all other genera 2aperturate pollen grains are found together with 3-aperturate ones. Chaw and Darwin (1992) describe pollen of Antirhea as inaperturate or 1-porate; D'hondt et al. (2004) report monoaperturate pollen grains in Blepharidium Standl.; Huang (1972) described pollen of Hedyotis diffusa Willd. (= Oldenlandia diffusa (Willd.) Roxb.) as 1-5 colporate, and Huxley and Jebb (1993) observed 1-3-porate pollen grains in Myrmecodia. These observations of monoaperturate pollen grains in Rubiaceae need confirmation, and their viability should be investigated.

The number of apertures may vary considerably within a genus, which is illustrated for Spermacoce L. (Dessein et al., 2002a), in which a weak positive correlation has been found between pollen size and number of apertures. If the pantoaperturate species are excluded from the test, the correlation is strong. Also, within Danais Comm. ex Vent. there seems to be a correlation between pollen grain size and the number of colpori. Taxa with invariably 3- or $3(-4)$-colporate grains tend to have smaller grain sizes, and species with 4(-5)-colpori have larger grains (Buchner \& Puff, 1993).

\section{b. Position}

In most Rubiaceae, pollen is angulaperturate-i.e., the apertures are situated at the angles of the outline in polar view (Fig. 12) -with the apertures situated only at the equator 
(zonoaperturate). Planaperturate pollen-i.e., apertures situated at the sides when seen in polar view (Fig. 13) - is observed in a few species only; for example, Rondeletia odorata Jacq. (ElGhazaly et al., 2001) and Spermacoce stenophylla (Dessein et al., 2005b). Pantoaperturate grains with the apertures evenly spread over the pollen surface (e.g., in Geophila repens, Spermacoce phyteuma Schweinf. ex Hiern, and S. annua Verdc.) occur sporadically in the family (Fig. 18). Two remarkable, previously unreported, organization patterns were recently observed in Spermacoce (Dessein et al., 2002a). The first type has several short colpori arranged in a looplike pattern (Fig. 16), similar to the line on a tennis ball (S. filifolia (Schumach. \& Thonn.) J.-P. Lebrun \& Stork, S. octodon J.-P. Lebrun \& Stork, and S. tenuissima Hiern). In the second type (Fig. 17), the colpori are arranged in a spiral pattern (S. terminaliflora Good and S. thymoidea (Hiern) Verdc.). To our knowledge, these two types of aperture position have not previously been observed in angiosperms. These types can be considered intermediate forms between zono- and genuine pantoaperturate grains. In Coffea L., spiraperturate and syncolporate grains may occur, probably because of hybridization events (Chinnappa \& Warner, 1981, 1982; Stoffelen et al., 1997).

\section{c. Type}

The aperture type of Rubiaceae pollen is a major character for identification and often useful for inferring phylogeny. Compound apertures are the rule; that is, two or three (non)congruent apertures on top of each other, situated in different layers of the wall. A full set of apertures thus consists of an ectoaperture, which is a thinning or hole in the sexine, a mesoaperture situated in the foot layer, and an endoaperture in the endexine and/or membranous granular layer MGL (see below for details). The first comprehensive analysis of the structure of Rubiaceous apertures was made by Lobreau-Callen (1978). Much confusion is caused by the terminology of pollen classes such as colporate or pororate, because they are used mostly on the basis of external SEM observations only. When a grain has undifferentiated ectocolpi (without mesoapertures) in external equatorial view, it is usually named "colpate." This is the case, for example, in Chiococca phaenostemon Schlecht. (Huysmans et al., 1999). However, on broken grains or in LM, endocolpi are visible with diverging ends perpendicular to the ectocolpi. According to the definition in Punt et al. (1994), Chiococca P. Br. is thus colporate. Consequently, the thinnings at the inside of the pollen wall merit closer examination (see under endoapertures).

We propose to follow the terminology of Punt et al. (1994) and hence to use the term "colporate" for the combination of an ectocolpus with any other aperture, whether a mesoaperture is visible at the outside, an endoaperture is visible only at the inside of the grain, or both. For cladistic analyses, however, the character aperture type should be coded in a different way (cf. below).

Grains with an apertural system consisting of three compound apertures are believed to be plesiomorphic in Rubiaceae. A restricted number of genera-for instance, Galium L. (truly colpate) - have pollen with less-differentiated, single apertures.

Ectoapertures, apertures in the outer layer of the sporoderm, can be colpi (Figs. 19-21) or pori (Figs. 22-24). The length of the colpi is very variable and sometimes demarcates genera or groups of related species. Colpus endings are equally variable. They can be truncate, acute, obtuse, or, more rarely, fishtail shaped. The colpus membrane can be smooth or granular (Fig. 19).

Opercula, or sexinous structures that cover part of the ectoaperture, were only observed in a few species with pantoaperturate grains: Geophila repens (Fig. 23; Vanthournout, 2002), and in at least two species of Spermacoce (Fig. 24; Dessein et al., 2002a). Opercula-like structures are also shown, but not discussed, for Sarcopygme pacifica (Reinecke) Setchell \& Christoph (Darwin, 1979). 

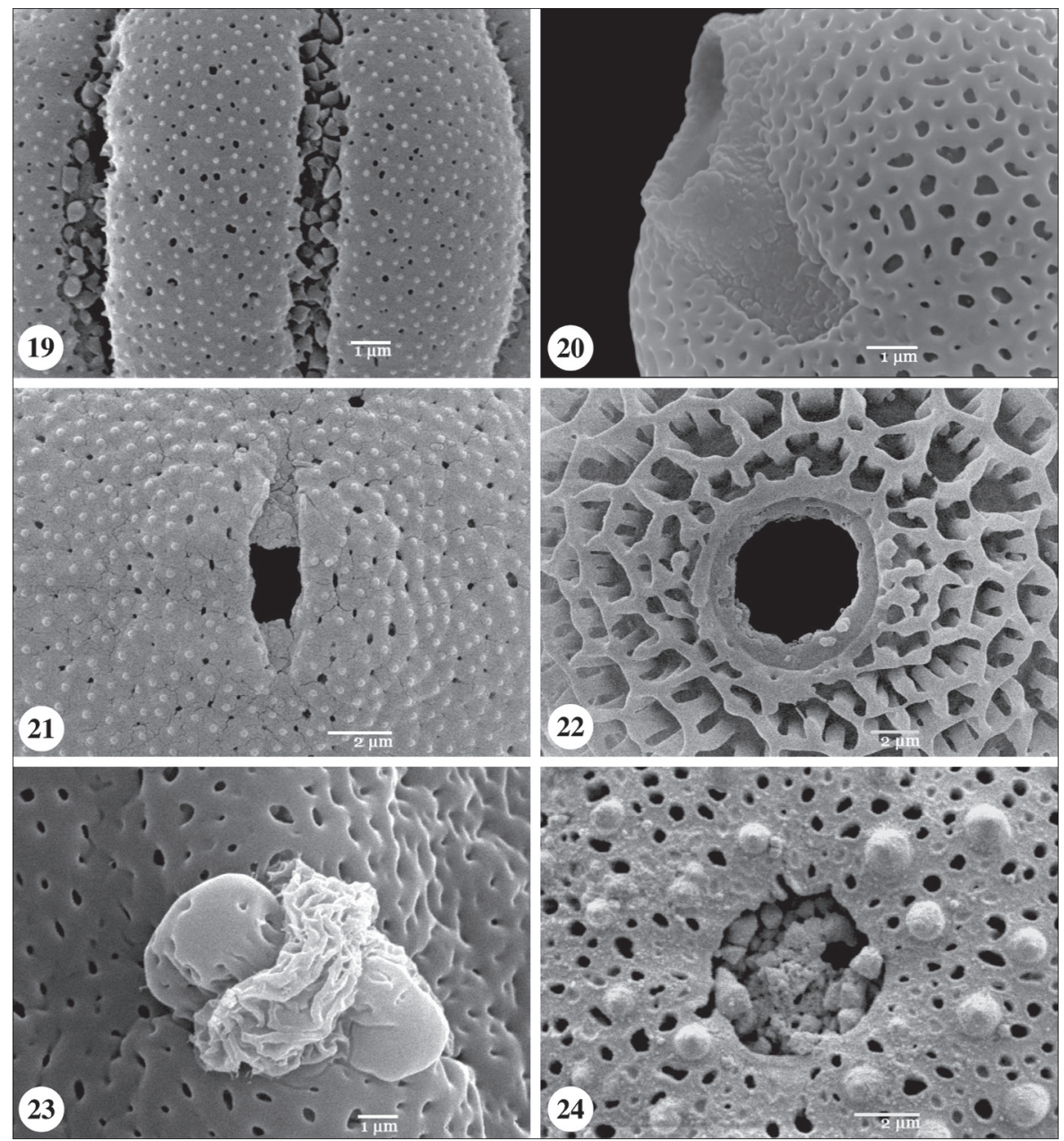

Figs. 19-24. Aperture types. 19. Detail of a colpus of Galium pumilum Murr. (Huysmans et al., 2003). 20. Detail of a colporus of Pseudomussaenda stenocarpa (Hiern) E. M. A. Petit (Huysmans et al., 1998a). 21. A short colporus of Conostomium kenyense Bremek. (S. Dessein, unpubl. data). 22. A porus of Psydrax subcordata (Lens et al., 2000). 23. Detail of a porus of Geophila repens, with two opercula separated by an intine plug (K. Es, unpubl. data). 24. A porus of Spermacoce phyteuma, with granular operculum, (Dessein et al., 2002a).

Mesoapertures, if present, are pores (Fig. 20). Thickenings around these pores are common, either visible at the outside (aspis) or at the inside (here called "costa"). The combination of an ectocolpus with a perpendicular endocolpus may result in a square hole at the equator (Fig. 21). It is not a well-defined mesoporus but merely the intersection of the two other apertures.

The variation in endoapertures in Rubiaceae is large and has significant systematic value. Many Rubiaceae, including their earliest derived members, show an endoaperture perpendicular to the ectocolpus. Endocolpi are the predominant endoaperture in Rubiaceae (Fig. 28). The endocolpus ends vary from acute to obtuse or fishtail shaped. Next to endocolpi, endocinguli 

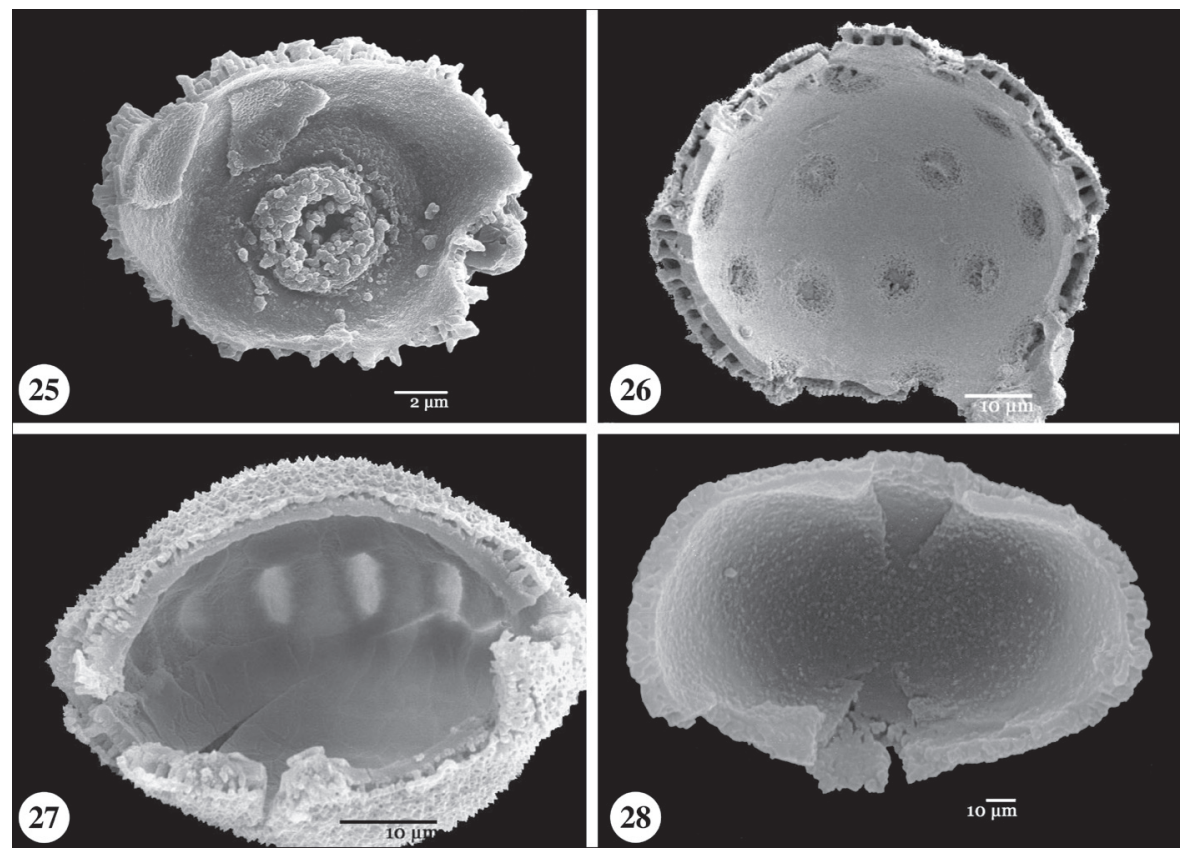

Figs. 25-28. Endoaperture types. 25. View of the inside of a pollen grain, showing a coarse costa of Capirona decorticans Spruce (S. Huysmans, unpubl. data). 26. Inside view of a pollen grain of Spermacoce phyteuma, with many indistinct endopores (Dessein et al., 2002a). 27. Inside view of a pollen grain, showing an endocingulum of Spermacoce azurea Verdc. (Dessein et al., 2002a). 28. Inside view of a pollen grain of Pentas bussei Krause, showing endocolpi (Dessein et al., 2000).

are also frequently observed (Fig. 27). There are strong arguments to assume that endocolpi may fuse into an endocingulum, because many intermediate forms are observed (Dessein et al., 2000). Moreover, in many tribes both endocinguli and endocolpi occur. Some porate species have endopores surrounded by circular costae (Fig. 25). When ectopores and endopores are congruent, we, and many other authors, use the term "porate" to describe the pollen grains. In this case, endoapertures are considered to be absent, although the condition may derive from pollen grains with incongruent endo- and ectoapertures.

Endoapertures can become very complex by the presence of extensions or by additional thinnings within, for example, an endocingulum. The tribe Spermacoceae s.str. exhibits intricate endocingula with two opposite triangular extensions in each mesocolpium and spindleshaped thinnings underneath each ectocolpus (Fig. 27; Dessein et al., 2002a). In the Portlandia-Exostema-Catesbaeeae-Chiococceae-group (hereafter referred to as the "PECC-complex"), four distinct types of nexine ornamentation were described in spite of their uniform external pollen morphology. The most pronounced type in the group is the combination of an endocingulum with a single, broad extension in each mesocolpium. These extensions fuse at the poles, forming a star-shaped thinning. Near each ectoaperture, four smaller extensions are present, two at each side of the endocingulum, which fuse with the mesocolpial bands near the poles. In the cutaways, a smooth, perforated layer crops out (Huysmans et al., 1999). In Scandentia E. L. Cabral \& Bacigalupo, Cabral and Bacigalupo (2001) observed several endoapertures for each ectocolpus. 

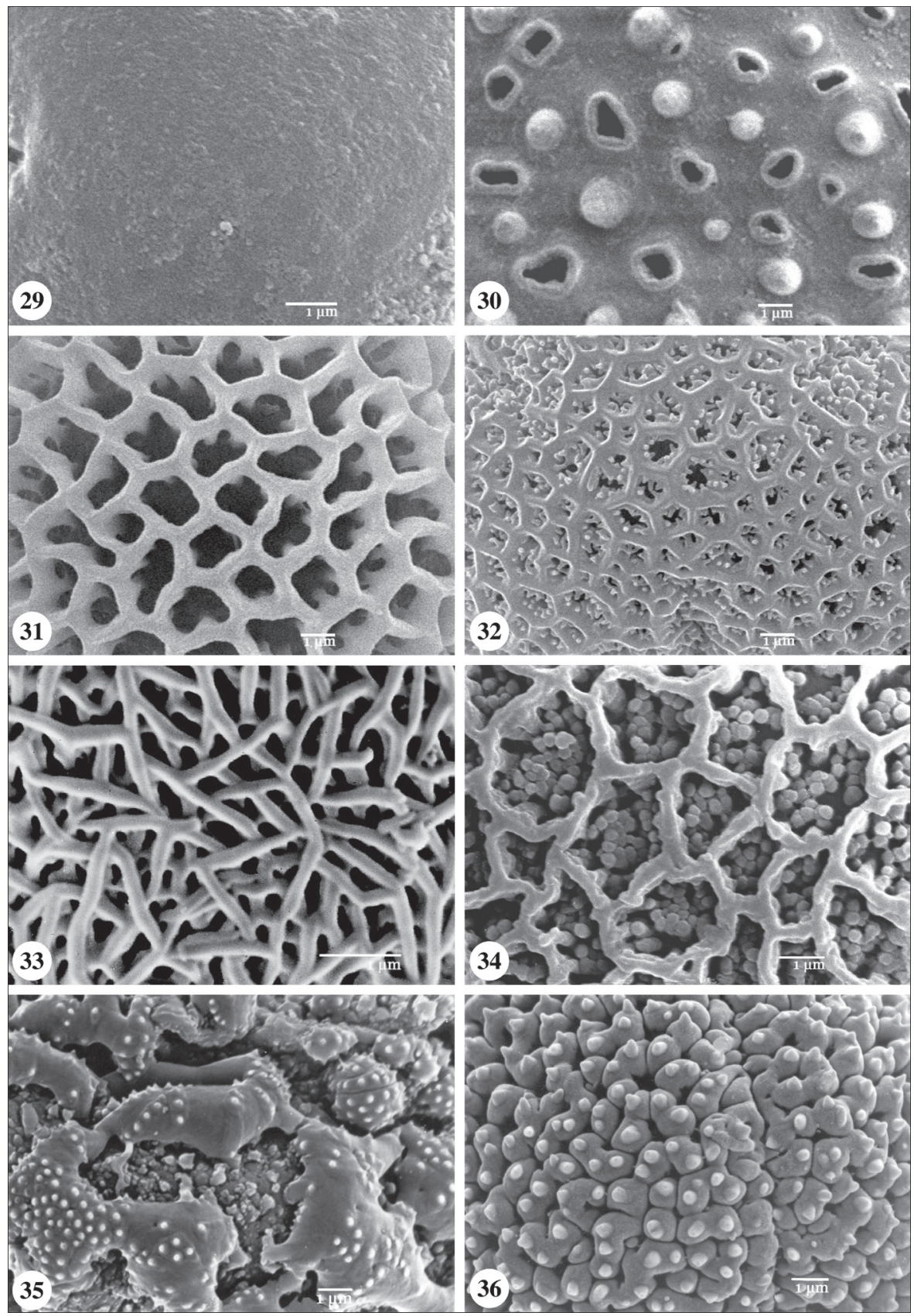

Figs. 29-36. Sexine patterns. 29. Detail of an apocolpium, showing a psilate tectum, of Spermacoce natalensis (Dessein et al., 2002a). 30. Detail of a mesocolpium, showing a perforate-foveolvate sexine with bordered pits, of Spermacoce bambusicola (G. Don) Bullock ex Hoyle (Dessein et al., 2002a). 31. Detail of a mesocolpium, showing a reticulate sexine, of Kohautia longifolia Klotzsch (S. Dessein, unpubl. data). 


\section{d. Protruding Onci and Pollen Buds}

In many angiosperm species, a lens-shaped structure that is not resistant to acetolysis and occurs beneath the aperture is formed. In Rubiaceae, these onci sometimes protrude through the apertures, forming papillae (Fig. 1). This feature has been discussed for Oldenlandia nudicaulis Roth (Farooq \& Inamuddin, 1969), Stephegyne parviflora Korth. (? = Mitragyna sp.) (Ramam, 1954), and Mitriostigma axillare Hochst. (Hansson \& El-Ghazaly, 2000). In many other publications, similar structures are seen in illustrations of unacetolyzed pollen grains of other taxa but are not discussed in detail; as, for example, in Atractocarpus (Puttock, 1992), Gardenia Ellis (Puttock, 1992), Scyphiphora C. F. Gaertn. (Puff \& Rohrhofer, 1993), and Strumpfia Jacq. (Igersheim, 1993a).

In SEM, these protruding onci look very similar to pollen buds, which were reported in Mussaenda L., Ophiorrhiza L., Pseudomussaenda Wernham, and Schizomussaenda Li (Chennaveeraiah \& Shivakumar, 1983; Igersheim \& Weber, 1993; Mathew \& Philip, 1987; Philip \& Mathew, 1975; Puff et al., 1993b). The protoplasmatic vesicles seen in Myrmecodia (Robbrecht, 1988a) are probably also pollen buds. Pollen buds are larger than the protruding onci and differ in the fact that they possess a vacuole. According to Igersheim and Weber (1993) and Weber and Igersheim (1994), they also differ in separating from the pollen grains before shedding. Tilney and Van Wyk (1997) report protrusions of intine, often in addition to protoplasm in Canthium Lam., Keetia, and Psydrax. Although their work includes TEM observations, they do not distinguish protruding onci from pollen buds.

\section{Sexine}

Rubiaceae show a wide array of morphological variation in sexine patterns, including psilate (Fig. 29), perforate (Fig. 30), foveolate, (micro)reticulate (Figs. 31-34), rugulate, rugulate-clavate, articulate, hamulate, striate, and double reticulate (Fig. 32). The majority of the species have a tectum perforatum or are (micro)reticulate. In Mycetia javanica (Blume) Reinw. ex Korth., the thick tectum is very irregular. with elongated or rounded processes beset with unequally spaced microspines (Fig. 35). Another strange sexine is observed in Gouldia terminalis (Hook. \& Arn.) Hillebr., in which the bacula are interconnected and beset with microspines (Fig. 36).

A double or complex reticulum characterizes the tribe Coccocypseleae (Piesschaert et al., 2000b). It also occurs in Pavetteae (De Block \& Robbrecht, 1998), Spermacoceae s.l. (Dessein, 2003; Groeninckx, 2005; Pire, 1997a; Pire \& Cabral, 1992), and the genus Metabolos (Puff \& Igersheim, 1994a). A double reticulum consists of a smooth "suprareticulum" and a spinulate "infrareticulum" situated at a level slightly below the suprareticulum (Fig. 32). At present, it is unclear whether all structures named "double reticulum" in Rubiaceae are structurally identical. An in-depth TEM study is needed to verify this hypothesis.

Atectate grains are rare but do occasionally occur in Psychotrieae and in Versteegia Valeton (Pavetteae; De Block \& Robbrecht, 1998). Versteegia cauliflora (K. Schum. \& Lauterb.) Valeton has free-standing bacula on the foot layer.

Figs. 29-36, continued

32. Detail of an apocolpium, showing a double reticulum, of Hedythyrsus thamnoideus (S. Dessein, unpubl. data). 33. Detail of a mesocolpium of Tarenna drummondii Bridson, showing interwoven muri forming a microreticulate pattern (De Block \& Robbrecht, 1998). 34. Detail of a reticulate sexine. with free bacula in the lumina, of Capirona decorticans (Huysmans et al., 1998a). 35. Polar view of Mycetia javanica, showing the very irregular, thick tectum, the elongated or rounded processes beset with unequally spaced microspines, and the granular foot layer (Huysmans et al., 1998a). 36. Detail of the interconnected bacula, with microspines, of Gouldia terminalis (Huysmans et al., 1998a, as Gouldia ovata (Wawra) Skottsb.). 


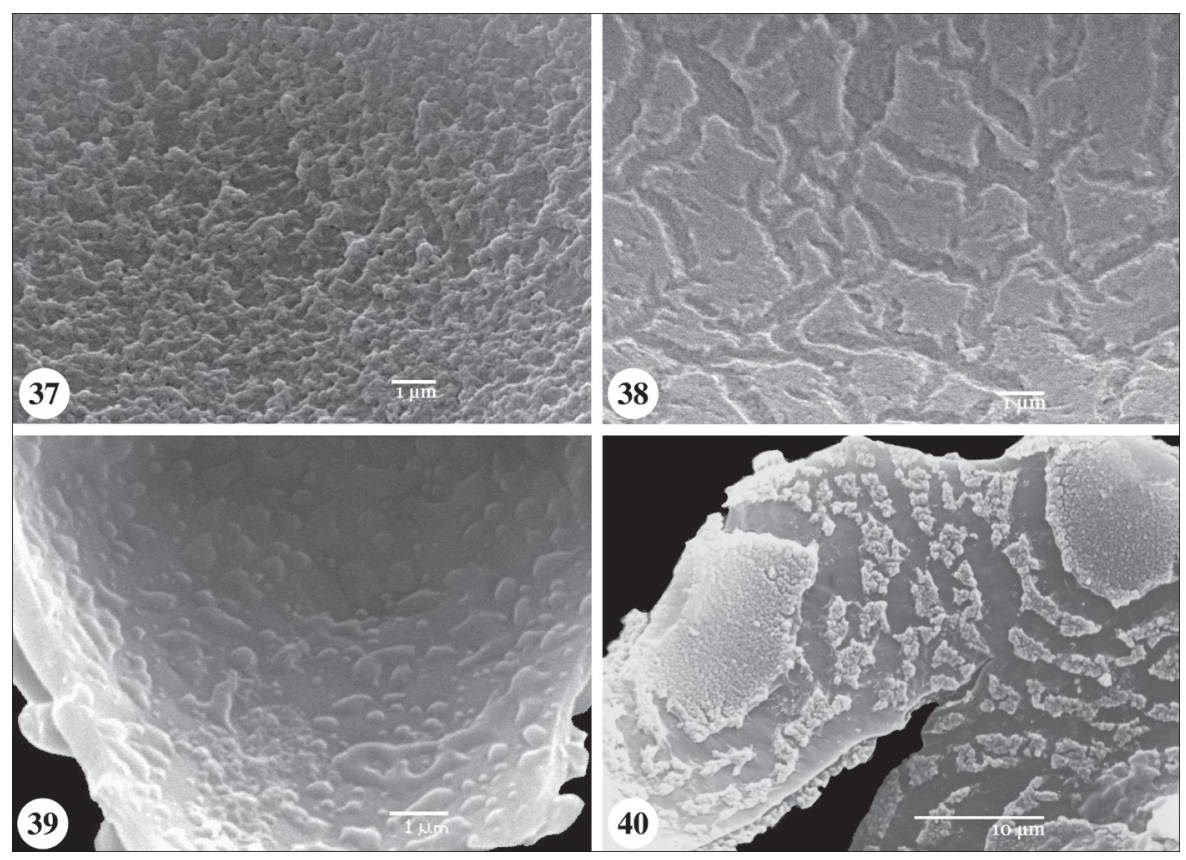

Figs. 37-40. Inner nexine surface types. 37. View of a granular inner nexine surface of Ernodea littoralis Sw. (Dessein, 2003). 38. View of an inner granular nexine surface, with endocracks, of Spermacoce dibrachiata (Dessein et al., 2002a). 39. View of an inner nexine surface of Coptosapelta flavescens Korth., showing bumpy and smooth surface (J. Verellen, unpubl. data). 40. Inside of a pollen grain of Gaertnera vaginata Poir., showing islands of granular nexine separated by broad endocracks (Jansen et al., 1996a).

Supratectal elements are absent in the majority of Rubiaceae. A number of tribes have pollen both with and without supratectal elements; for example, Coffeeae, Pavetteae, and Gaertnereae. Only in a few taxa-e.g., Rubieae (Huysmans et al., 2003) and all 24 genera of the PECC-complex (Huysmans et al., 1999, unpubl.) - the sexines are invariably echinate. The supratectal elements can be (micro)spines, microgemmae or microverrucae, or tiny striae. In several Australian Gardenia species, pollen grains with small gemmae intermingled with very large ones have been observed (Puttock, 1992).

Distinct margines of supratectal elements are rather exceptional. In Spermacoce natalensis Hochst., for instance, spines occur in an elliptic field around the ectocolpus but the rest of the sexine is psilate (Dessein et al., 2002a).

\section{Nexine Ornamentation}

The inside of acetolyzed Rubiaceae pollen is often granular. The nature of this granular layer was recently studied ontogenetically and histochemically by El-Ghazaly and Huysmans (2001). They found that it is a distinct wall layer with a particular mode and timing of development, different from both the endexine and the intine. Histochemically, this layer differs from the endexine in having fewer lipids and more proteins and is distinguished from the intine in containing more pectin and less acidic polysaccharides. The granular layer also resists acetolysis and was called the "membranous granular layer" (MGL). El-Ghazaly and Huysmans (2001) 
describe a MGL in four dicots (including Rondeletia odorata) and one monocot. The thinnings often observed at the inside of acetolyzed Rubiaceae pollen are located in the MGL and not in the endexine. For an unambiguous understanding, we prefer to use the circumscription "inner surface of the nexine" in what follows.

The systematic importance of nexine characters at the inside of pollen grains is repeatedly stressed in Rubiaceae (Jansen et al., 1996a; Van Campo, 1978), and we are fully convinced of their potential as phylogenetic markers (Huysmans et al., 1998a, 1999). The ornamentation of the nexine is mostly granular (Fig. 37); few genera have an entire smooth inner nexine surface (e.g., Chazaliella E. M. A. Petit ex E. M. A. Petit \& Verdc.). In Coptosapelta Korth. the nexine is bumpy, like water droplets on an oily surface (Fig. 39; Verellen et al., 2004).

Irregular grooves in the inner nexine surface, called "endocracks," are common in Rubiaceae (Fig. 38). They sometimes reduce the granular layer into isolated patches, as clearly seen in Isertia Schreb. (Huysmans et al., 1998a), Capirona Spruce, and Gaertnera Lam. (Fig. 40; Jansen et al., 1996a).

\section{Stratification of the Pollen Wall}

In general, Rubiaceae pollen corresponds to the basic pattern of pollen-wall stratification in angiosperms: tectum, columellae, foot layer, endexine, intine (Figs. 41-42, 44). The relative proportions of the respective layers are variable, even within one pollen grain. In a few genera (e.g., Coptosapelta, Durringtonia) columellae are reduced or totally lacking (Fig. 43). Atectate pollen has so far been observed only in Versteegia cauliflora (De Block \& Robbrecht, 1998). Free-standing bacula in the lumina of a reticulate sexine (Fig. 34) occur in several species belonging to at least 21 genera scattered all over the family. It seems to be a typical character for many genera of the Morindeae (e.g., Prismatomeris Thawaites, Caelospermum Blume).

\section{B. HETEROSTYLY AND POLLEN DIMORPHISM}

Barrett (1992: 1) defined heterostyly as "a genetic polymorphism in which plant populations are composed of two (distyly) or three (tristyly) morphs that differ reciprocally in the heights of stigmas and anthers in flowers." Heterostyly is very common in Rubiaceae (cf. Anderson, 1973; Bir Bahadur, 1968b; Bremekamp, 1952, 1966), especially in genera of Psychotrieae and Spermacoceae s.l. (Robbrecht, 1988a). Given that congeners of heterostylous species are often homostylously ancestral, it must have evolved repeatedly in the family (Anderson, 1973). Pollen size dimorphism is often correlated with heterostyly. As a rule, pollen of the brevistylous morph is slightly larger than pollen in flowers with long styles (Bir Bahadur, 1963, 1966, 1968a, 1968b, 1970; Bir Bahadur \& Rama Swamy, 1993; Bremekamp, 1963; Jung-Mendaçolli \& Melhem, 1995; Naiki \& Nagamasu, 2003; Pailler \& Thompson, 1997). However, the opposite situation is reported in Pentas schimperiana Vatke (Dessein et al., 2000), Pseudosabicea arborea (K. Schum.) N. Hallé (Huysmans et al., 1998a), and Hindsia longiflora (Cham.) Benth. (Di Maio, 1996). In these species the larger pollen grains are observed in the longistylous flowers. However, one must bear in mind that size differences are usually slight and become obscured if different populations are compared (Puff, 1988).

Two other cases of pollen dimorphism correlated with heterostyly are frequently reported: variation in aperture number and sexine ornamentation. Baker (1956), for example, reported "spiniferous" pollen grains in short-styled flowers of Rudgea and "smooth" pollen grains in long-styled flowers. Similar cases are reported for several other genera scattered all over the family; for example, for the Danais-Payera-Schismatoclada complex (Buchner \& Puff, 1993). In several species of Coccocypseleae, a tribe characterized by a double reticulum, it has been 

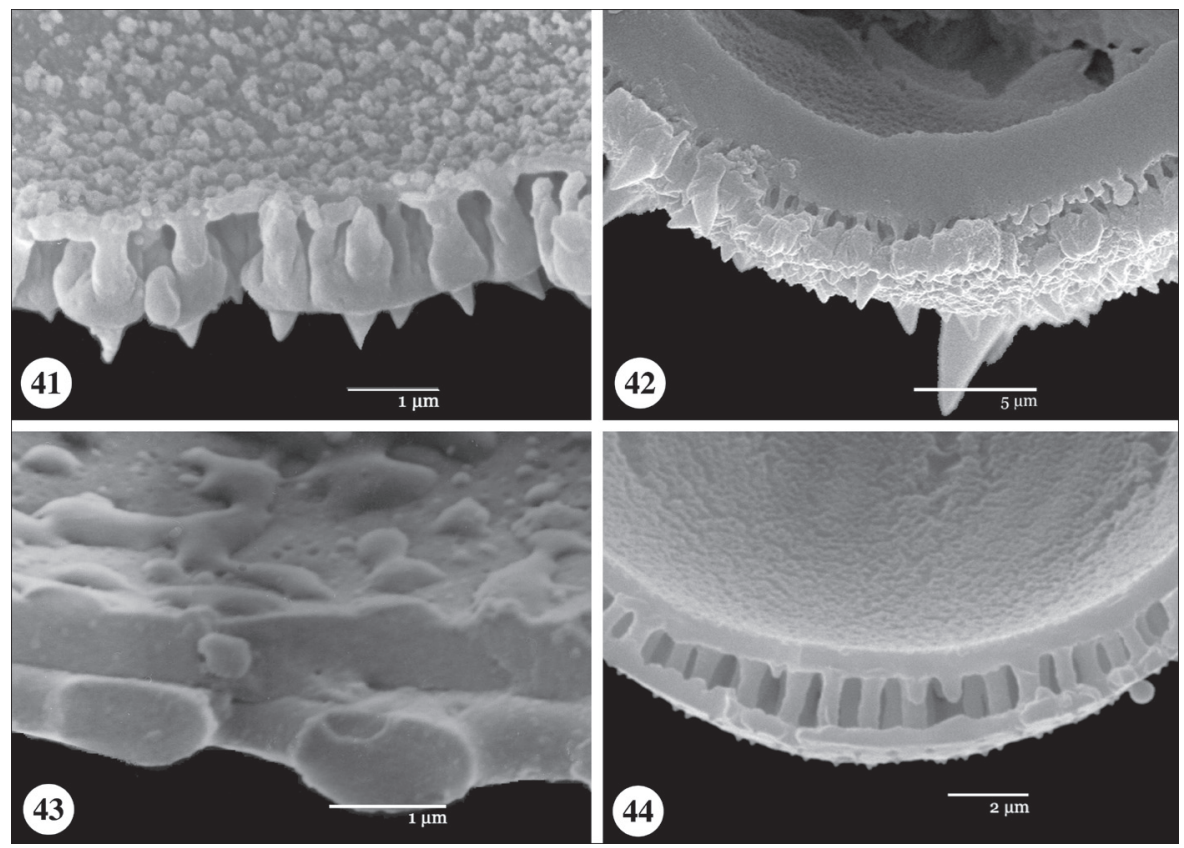

Figs. 41-44. Pollen wall stratification. 41. A broken pollen wall of Gouldia terminalis, showing a massive tectum with microspines and relatively thin endexine (Huysmans et al., 1998a, as Gouldia ovata). 42. A broken pollen wall of Richardia grandiflora (Cham. \& Schltdl.) Steud., showing very thick endexine and huge spines on the tectum (P. De Vré, unpubl. data). 43. Cross-section of a pollen wall of Coptosapelta olaciformis (Merr.) Elmer, showing sexine without columellae (S. Huysmans, unpubl. data). 44. Cross-section of a pollen wall of Spermacoce sp., showing more or less equally thick endexine, columellae, and tectum layers (S. Dessein, unpubl. data).

observed that the infrareticulum is better developed in the brevistylous flowers than in the longistylous flowers. Pire and Cabral (1992) made a similar observation for the genus Galianthe Griseb. (Spermacoceae s.str.). In most cases, however, the difference between the exine of the brevistylous and longistylous morphs is less pronounced: The dimorphism is often limited to a coarser reticulation in the thrum grains (Bir Bahadur, 1968b). The pollen morphs of Sabicea capitellata Benth. and S. orientalis Wernham differ morphologically only in the ratio of 3-and 4-aperturate grains. Longistylous flowers of Sabicea capitellata have considerably fewer 4aperturate grains than do brevistylous flowers; only in the brevistylous morph do 5-aperturate grains occasionally occur. In Sabicea orientalis the opposite was observed: Brevi-pollen was mostly 3-aperturate, sometimes 4-aperturate, whereas the ratio of 3-/4-aperturate grains in longipollen is approximately 1 (Huysmans et al., 1998a). A more extreme example of difference in aperture number correlated with heterostyly was reported by Robbrecht (1977) in Hymenocoleus. Brevistylous individuals apparently produce nonaperturate pollen grains, whereas the longistylous flowers contain 3(-4-5)-porate grains. A SEM investigation of this genus should be undertaken, however.

In Pseudosabicea arborea, apart from size differences, pollen dimorphism is conspicuous in several other characters (Huysmans et al., 1998a). The sexine pattern is reticulate in longstyled flowers and perforate in short-styled flowers; apertures are larger in longistylous flowers; and the exine is twice as thick in longi-pollen $( \pm 2 \mu \mathrm{m})$ as in brevi-pollen $( \pm 1 \mu \mathrm{m})$. 


\section{ORBICULE CHARACTERISTICS OF RUBIACEAE}

Orbicules are tiny sporopollenin particles up to $3-4 \mu \mathrm{m}$ in diameter that line the inner tangential and radial walls of the tapetal cells (Huysmans et al., 1998b, 2000). Thus orbicules coat the inner locular surface and are in close contact with the pollen grains. Orbicules may have an electronlucent core, but they are always acellular structures. They are often, but not always, present in Rubiaceae.

The first report of the presence of orbicules in Rubiaceae was by Andronova (1984). She reported orbicules in several unrelated species of the family. Because her work was published in Russian, however, little attention has been paid to this study. Consequently, Pacini and Franchi (1993) did not include any Rubiaceae in their listing of angiosperm species with secretory tapetum reported to have orbicules. In the same year, Igersheim (1993a) reported the presence of orbicules in the monospecific Caribbean genus Strumpfia. Since then, two subfamilies of Rubiaceae have been screened for the presence of orbicules: Huysmans et al. (1997) investigated 14 genera of Cinchonoideae s.str., and Vinckier et al. (2000) studied 32 genera of Ixoroideae s.l. Orbicules have also been reported in several other genera. In Table II all present data are summarized at the generic level.

Six orbicule types can be described in Rubiaceae (Huysmans et al., 1997; Vinckier et al., 2000):

I. Spiny orbicules (Figs. 45-47). Orbicules are up to $3 \mu \mathrm{m}$ in diameter and are not embedded in tapetal membrane (although exceptional semi-embedded forms do occur). The orbicular wall is smooth but beset with a few to numerous spinules; one or a few perforations may occur. A core is absent or present.

II. Microrugulate orbicules (Fig. 48). Orbicules are less than $2 \mu \mathrm{m}$ in diameter and are embedded in the tapetal membrane. Their shape is more or less spherical, but they seem to consist of several elongated elements.

III. Smooth orbicules (Figs. 49-51). Orbicules are less than $1.4 \mu \mathrm{m}$ and are rarely embedded in the tapetal membrane. Aggregates of two or more orbicules may occur. The orbicular wall is smooth. Subtype IIIa has rounded, oblate orbicules with small perforations in the wall; subtype IIIb has more flattened, circular orbicules with a single central indentation (doughnut shaped).

IV. Irregularly folded orbicules (Figs. 52-53). Orbicules are irregular in shape and not spherical because of a folded surface. Perforations may occur, but a core is absent. They are not or only slightly embedded in tapetal membrane.

V. Granular orbicules (Figs. 54-55). Orbicules are flattened and irregular, 1-2 $\mu \mathrm{m}$ in diameter. The wall has several perforations, and small sporopollenine granules occur on the surface. A core is present, and they are often compound. They are not embedded in tapetal membrane.

VI. Embedded orbicules (Figs. 56-57). Orbicules are flattened, regular or irregular in shape and $0.5-1.6 \mu \mathrm{m}$ in diameter. Perforations and small sporopollenin granules may occur on the surface. Compound orbicules with several cores occur. The core-wall interface is not electron dense. They are embedded in tapetal membrane.

\section{FOSSIL POLLEN RECORD FOR RUBIACEAE}

Fossil data — both for microfossils and macrorests — are scarce for Rubiaceae. Muller (1981) provided the most recent overview of pollen records for the family. The oldest Rubiaceae pollen grains are recorded from the upper Eocene. The grains are similar to the tetrads observed in existing Gardenia species. During the Oligocene, Macrosphyra-type, Mitragyna-type, Farameatype, and Coprosma-type pollen grains appeared. These were followed by Scyphiphora-type, 


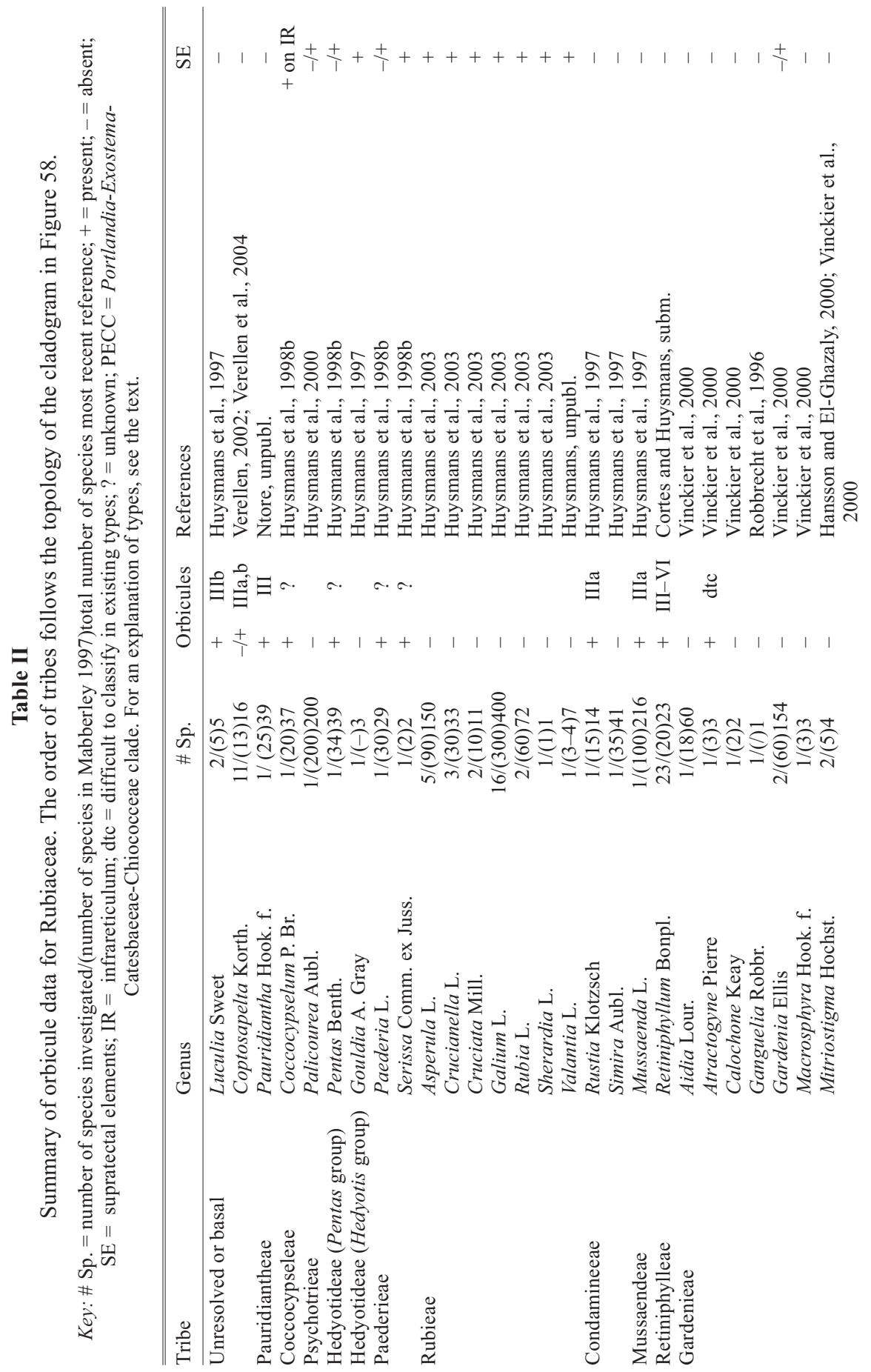




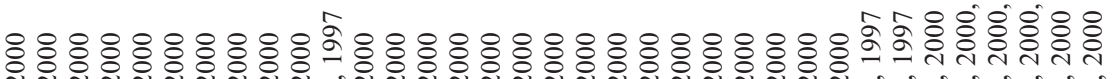

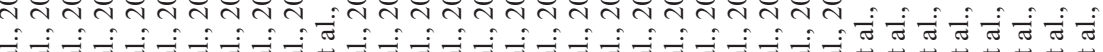

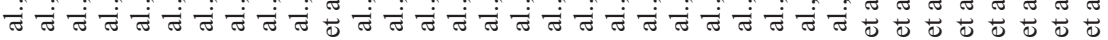

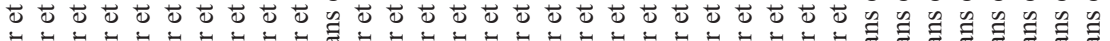

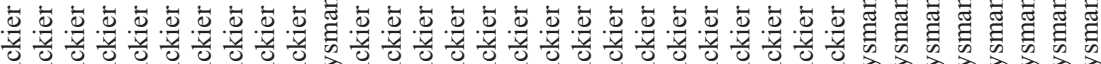

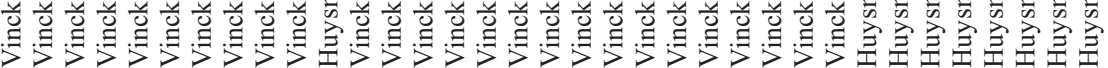

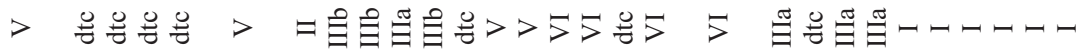

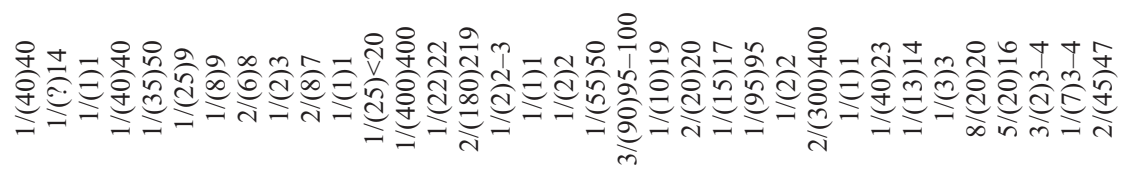

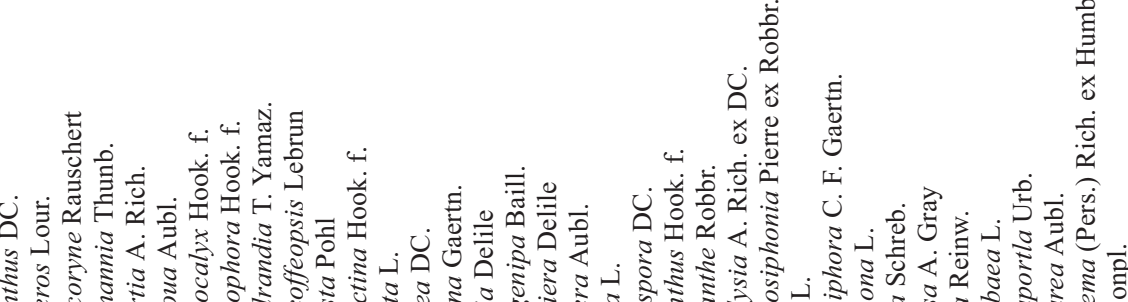

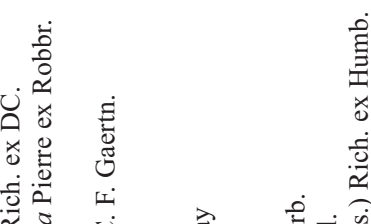
茥

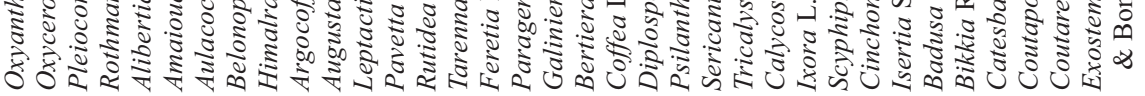

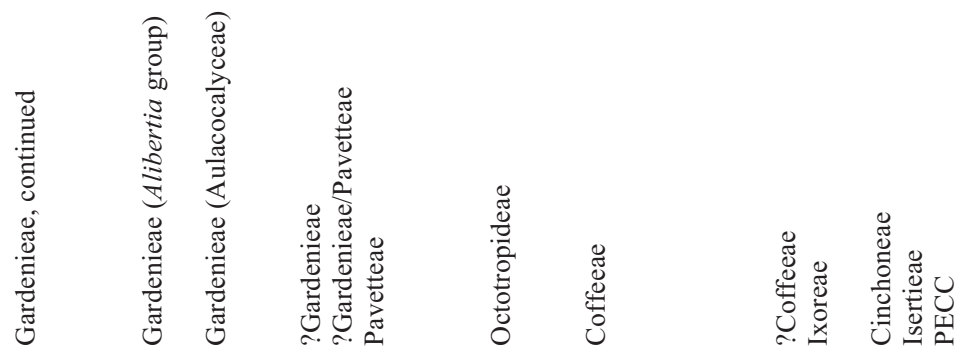




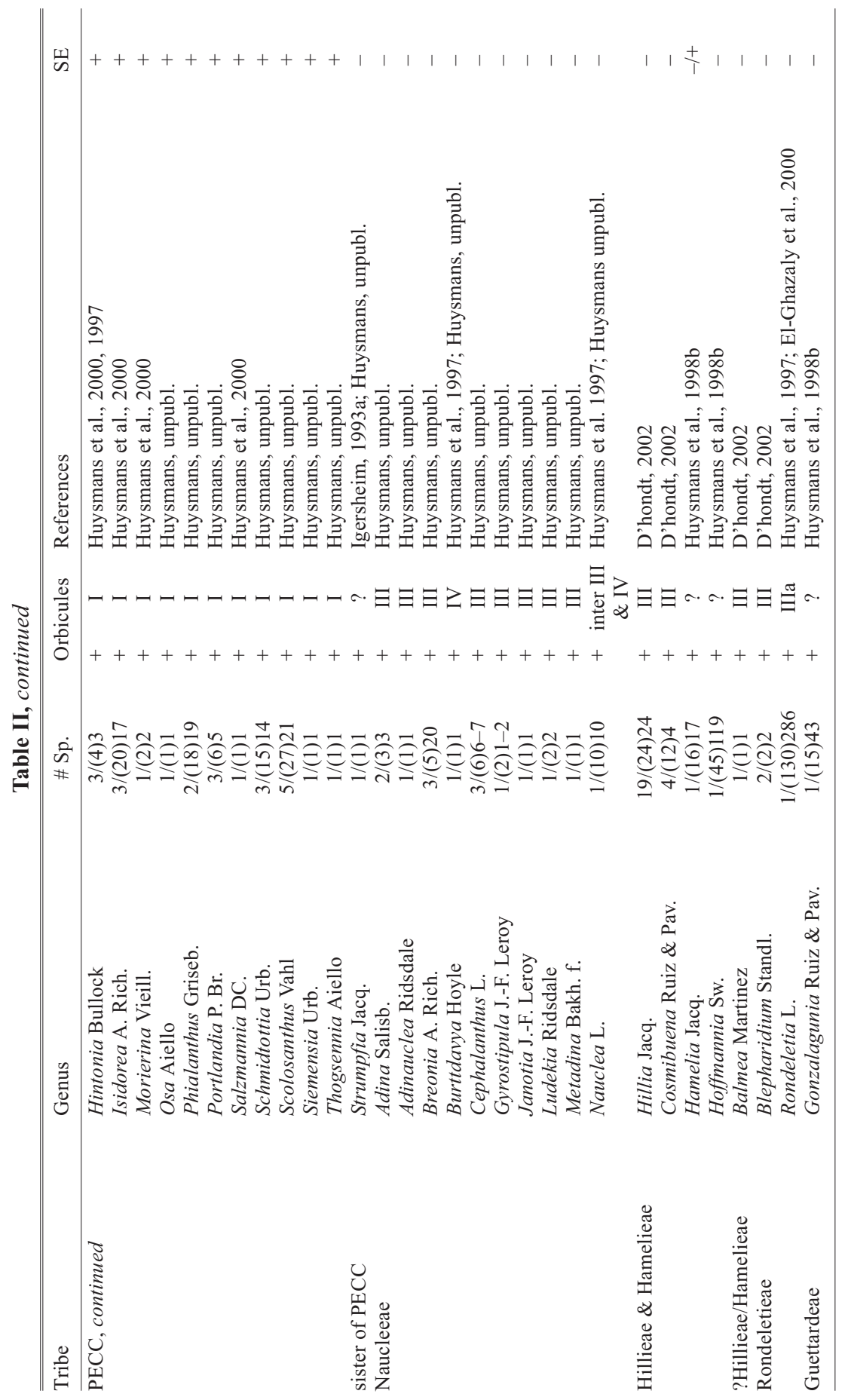


Sabicea-type, Morinda-type, Timonius-type, and Morelia-type pollen in the Lower Miocene. In the Upper Miocene, pollen of the more derived genera, such as Borreria G. Mey. and Rubia L., emerge in the fossil record. This pollen record is too fragmentary to draw solid conclusions about the evolution of pollen types in the family. Using the appearance of pollen types as calibration points for dating phylogenetic trees based on DNA sequence data should be done carefully.

\section{Discussion}

\section{A. SYSTEMATIC SIGNIFICANCE OF POLLEN MORPHOLOGY IN RUBIACEAE}

Pollen of the "average" Rubiaceae species is medium sized (30-40 $\mu \mathrm{m}), 3(-4)$-zonocolporate with an ecto- and endocolpus, subspheroidal, circular in outline, with a tectum perforatum mostly lacking supratectal elements. From the data gathered for the present article (see also Table I), it is clear that there are many variations on this theme.

The use of molecular data and cladistic procedures in systematics has resulted in wellsupported hypotheses on the phylogeny of the major groups of Rubiaceae. We use a summary cladogram (Fig. 58) that combines recent insights into the phylogeny of Rubiaceae to discuss the pollen variation in the family. The systematic value of pollen characters at the subfamily to specific level is illustrated below by several case studies.

\section{Subfamily Level}

The summary phylogenetic tree of Rubiaceae (Fig. 58) shows three major clades, which correspond to a certain extent with three of the four subfamilies recognized by Robbrecht (1988a): Rubioideae, Cinchonoideae s.str., and Ixoroideae s.l. The taxa of Robbrecht's fourth subfamily, Antirheoideae, are scattered over the tree. The molecular support for the monophyly of these three subfamilies is fairly convincing (see Andersson \& Rova, 1999; Andreasen \& Bremer, 2000; Bremer \& Manen, 2000), but morphological synapomorphies are scarce. For members of the Rubioideae, the presence of raphides is characteristic, but the other two subfamilies are mainly supported by molecular data.

Likewise, pollen morphological data by themselves are not useful in characterizing the subfamilies. No single pollen morphological character or complex of shared pollen features unambiguously identifies one of the subfamilies of Rubiaceae. The different character states of all pollen characters are scattered over the three subfamilies (Figs. 59-61; Table I) and hence originated several times in evolution. Verdcourt (1958: 226) already stated that "pollen grain characters are therefore not suitable as the main character for subdividing the family." It may be noted, however, that the pollen morphology of subfamily Cinchonoideae s.str. is more or less uniform, featuring small, 3(-4)-colp(or)ate and spheroidal grains often lacking supratectal elements (exceptions to this pollen type are found in the PECC-complex and Guettardeae); Rubioideae and Ixoroideae s.l. pollen grains show greater variation. Better sampling of the Cinchonoideae s.str., however, might prove that pollen is also more variable than currently estimated.

It is noteworthy that the more derived taxa of the Rubioideae often possess supratectal elements, whereas supratectal elements are lacking in the "basal" taxa. A similar pattern is observed among the Ixoroideae s.l., though supratectal elements are less common in this family (Fig. 59). In the subfamily Cinchonoideae s.str., supratectal elements are present only in the PECC-complex and a few species of the Hillieae, Rondeletieae, and Guettardeae.

It is of special interest that Coptosapelta and Luculia Sweet, two genera taking an isolated and often conflicting position with respect to the rest of the family, feature very different pollen grains. Pollen of Coptosapelta is highly derived, characterized by pororate grains having a wall 

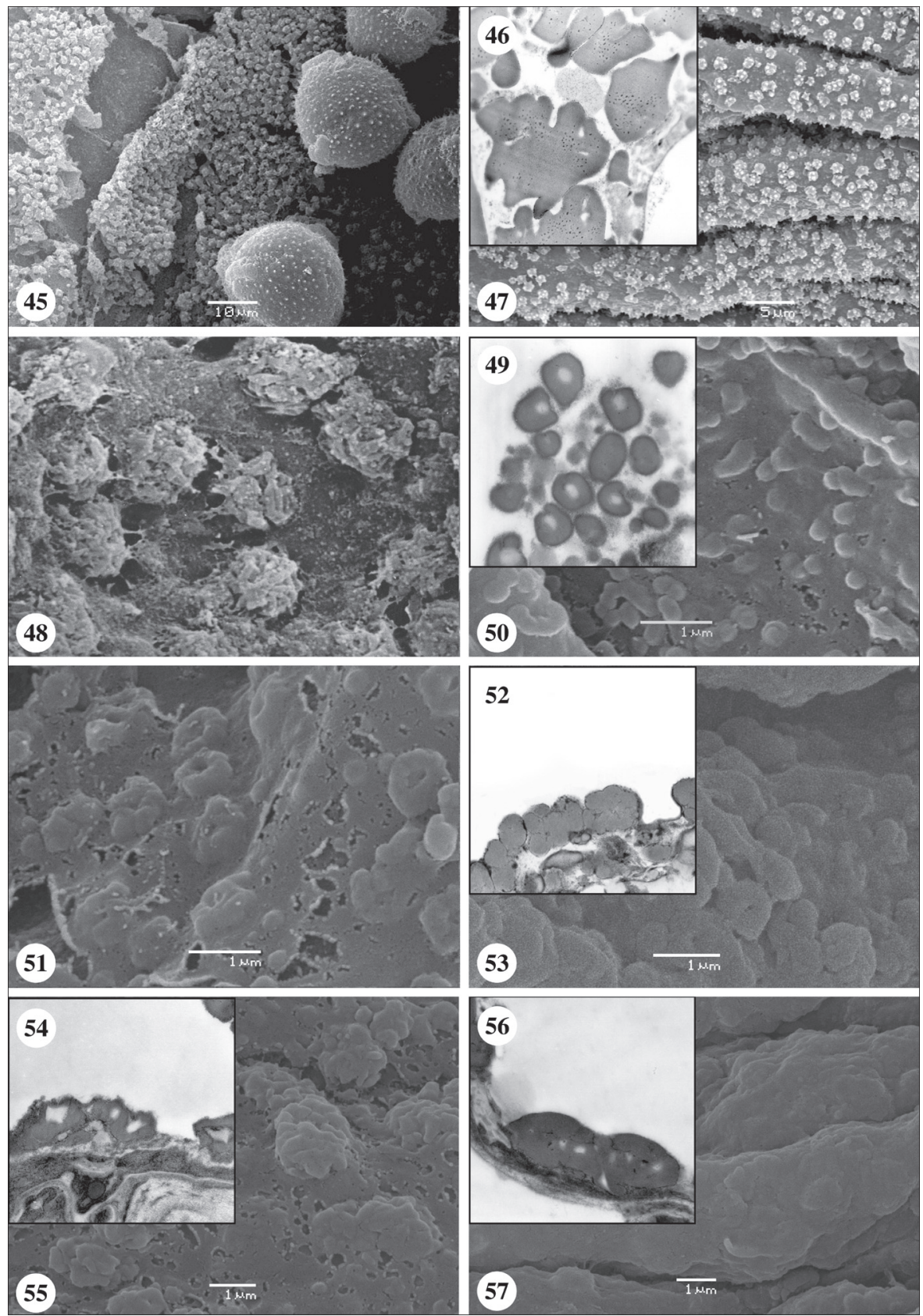

Figs. 45-57. Orbicule types. 45. Inner side of an anther wall of Exostema sp., showing tapetum cells with spiny orbicules and spinate pollen grains (H. Ochoterena, unpubl. data). 46. TEM photograph of spiny orbicules (Type I orbicules), as observed in Bikkia retusiflora (Huysmans et al., 1997). 47. SEM photograph of the inner side of an anther wall of Scolosanthus versicolor Vahl, showing tapetum cells covered with 
without columellae (Verellen et al., 2004). Similar pollen is found in some Guettarda species from Cuba (subfamily Cinchonoideae s.str.; Sotolongo Molina et al., 2002). Pollen of Luculia, on the contrary, matches what is thought to be the primitive pollen type for Rubiaceae; that is, small to medium-sized, more or less spheroidal, 3(-4)-colporate pollen with endocolpi and a reticulate tectum lacking supratectal elements. If the basal position of the genus Coptosapelta is confirmed in future phylogenetic analyses, its derived pollen illustrates the families' plasticity in pollen features from the beginning of its radiation.

\section{Tribal Level}

Although pollen is of little assistance on supporting the subfamilies defined by molecular studies, it often provides additional evidence for the circumscription of supertribes, tribes, and subtribes (Fig. 58). A few tribes are characterized by a pollen type that is not found in other members of the family. These pollen types are defined by a unique combination of pollen features rather than by the presence of a single diagnostic pollen character. A keen example is given by the pollen morphology of the PECC-complex. Molecular studies (e.g., Motley et al., 2005; Rova, 1999) have acknowledged the monophyly of this group, and Huysmans et al. (1999) demonstrated that pollen is remarkably stenopalynous within the complex. A unique pollen synapomorphy that characterizes all species is lacking, but the combination of relatively small grains, three ectocolpi, a perforated tectum beset with (micro)spines, and a complex endopattern comprising an endocolpus or endocingulum with numerous extensions is not observed in any other member of the family.

Other tribes that are remarkably stenopalynous and characterized by a peculiar pollen type are Danaideae (very small to small, 3-4(-5)-colporate pollen grains with a (micro)reticulate tectum), Rubieae (very small or small (rarely large) pluricolpate grains with a perforated tectum with (micro)spines), and Vanguerieae (po(ro)rate or short colporate grains, often with a costa). The tribe Naucleeae is also stenopalynous; at first sight, a special character that sets it apart from pollen grains of many other Rubiaceae, however, is lacking. Further research on the inside ornamentation of the grains may reveal that the H-shaped endoaperture that is frequently reported for the group is a useful synapomorphy (Verellen et al., submitted).

Sometimes, pollen morphological support for a clade is not immediately obvious. The clade formed by the Rubieae, Paederieae, and Theligoneae, for example, seems to be characterized

Text continues on p. 386

Figs. 45-57, continued

spiny orbicules (Type I orbicules) (S. Huysmans, unpubl. data). 48. SEM photograph of the inner side of an anther wall of Augusta longifolia (Spreng.) Rehder, showing tapetum cells covered with microrugulate orbicules (Type II orbicules) (Huysmans et al., 1997). 49. TEM photograph of smooth orbicules (Type IIIa orbicules), as observed in Luculia gratissima Sweet (Huysmans et al., 1997). 50. SEM photograph of the inner side of an anther wall of Cinchona josephiana Wedd., showing tapetum cells covered with smooth orbicules (Type IIIa orbicules). 51. SEM photograph of the inner side of an anther wall of Tarenna pallidula Hiern, showing tapetum cells covered with smooth orbicules with a single central indentation (Type IIIb orbicules) (S. Vinckier, unpubl. data). 52. TEM photograph of irregularly folded orbicules (Type IV orbicules), as observed in Alibertia pilosa K. Krause (S. Vinckier, unpubl. data). 53. SEM photograph of the inner side of an anther wall of Alibertia pilosa, showing tapetum cells covered with irregularly folded orbicules (Type IV orbicules) (S. Vinckier, unpubl. data). 54. TEM photograph of granular orbicules (Type V orbicules), as observed in Paragenipa cervorum Baill. (S. Vinckier, unpubl. data). 55. SEM photograph of the inner side of an anther wall of Paragenipa cervorum, showing tapetum cells covered with granular orbicules (Type V orbicules) (S. Vinckier, unpubl. data). 56. TEM photograph of embedded orbicules (Type VI orbicules), as observed in Bertiera racemosa K. Schum. (S. Vinckier, unpubl. data). 57. SEM photograph of the inner side of an anther wall of Coffea sessiliflora Bridson subsp. sessiliflora, showing tapetum cells covered with embedded orbicules (Type VI orbicules) (S. Vinckier, unpubl. data). 


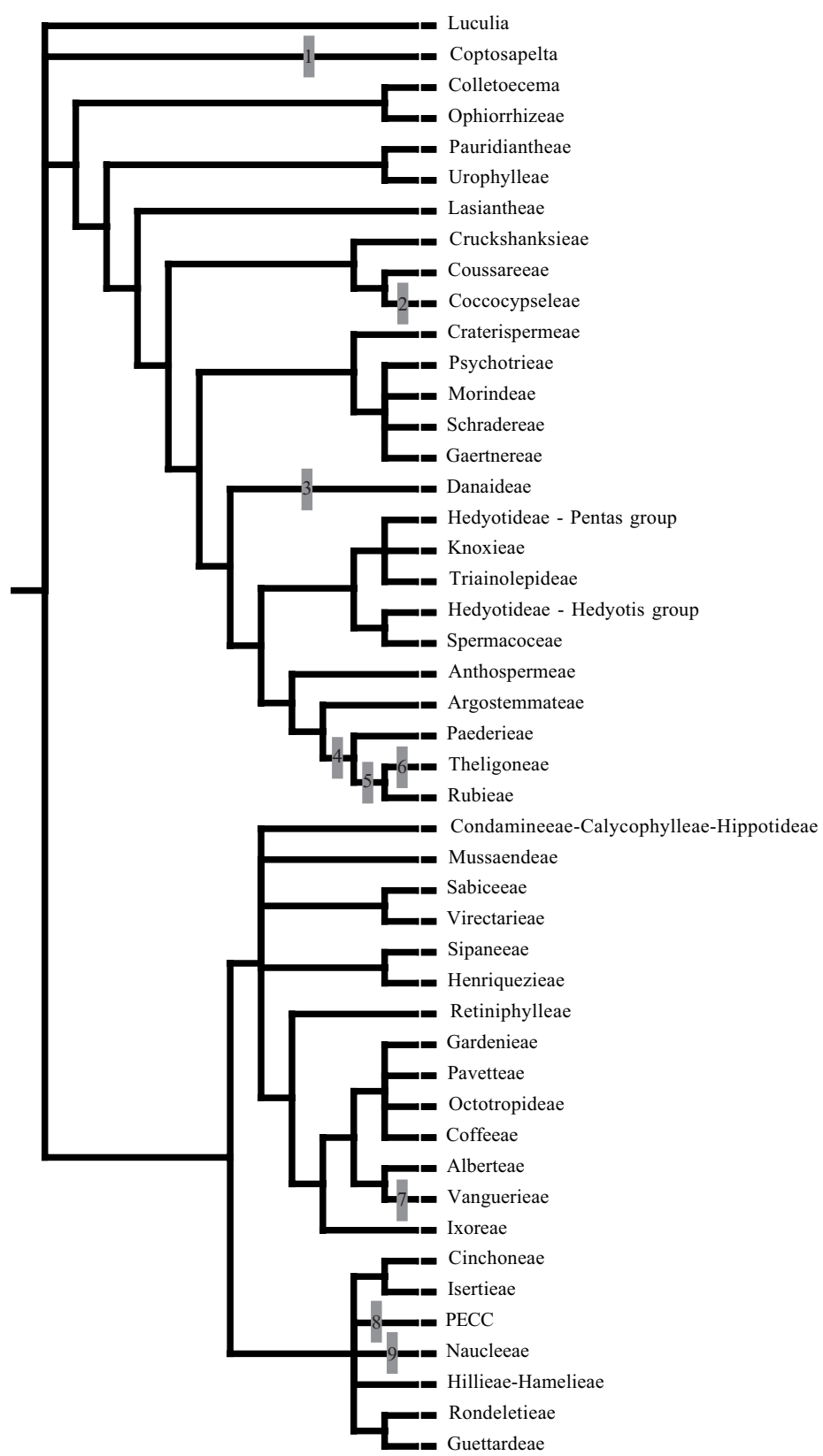

Fig. 58. Summary cladogram of Rubiaceae, giving recent insights into relationships between the tribes of the family, with indications of major pollen events that may represent synapomorphies. $1=$ Loss of columellae and origin of bumpy nexine surface. 2 = Origin of double reticulum. $3=$ Production of very small pollen grains. $4=$ Loss of endoaperture. $5=$ Amplification of number of apertures. $6=$ Transition from colpi to pores. $7=$ Reduction of ectocolpus length. $8=$ Production of supratectal elements and origin of complex endopattern. $9=$ Origin of H-shaped endoaperture. 


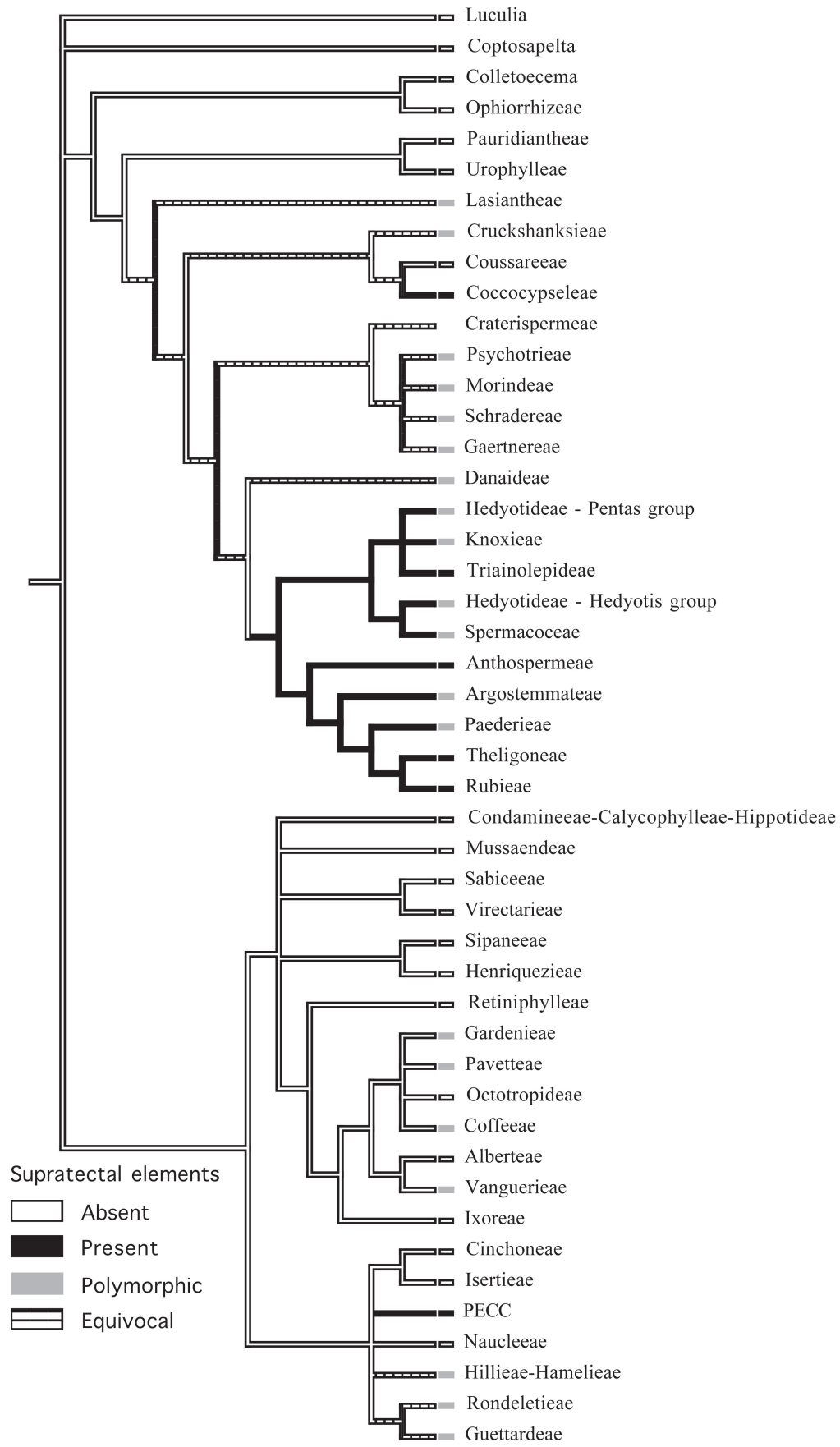

Fig. 59. Summary cladogram of Rubiaceae, showing the distribution of supratectal elements in the family. 


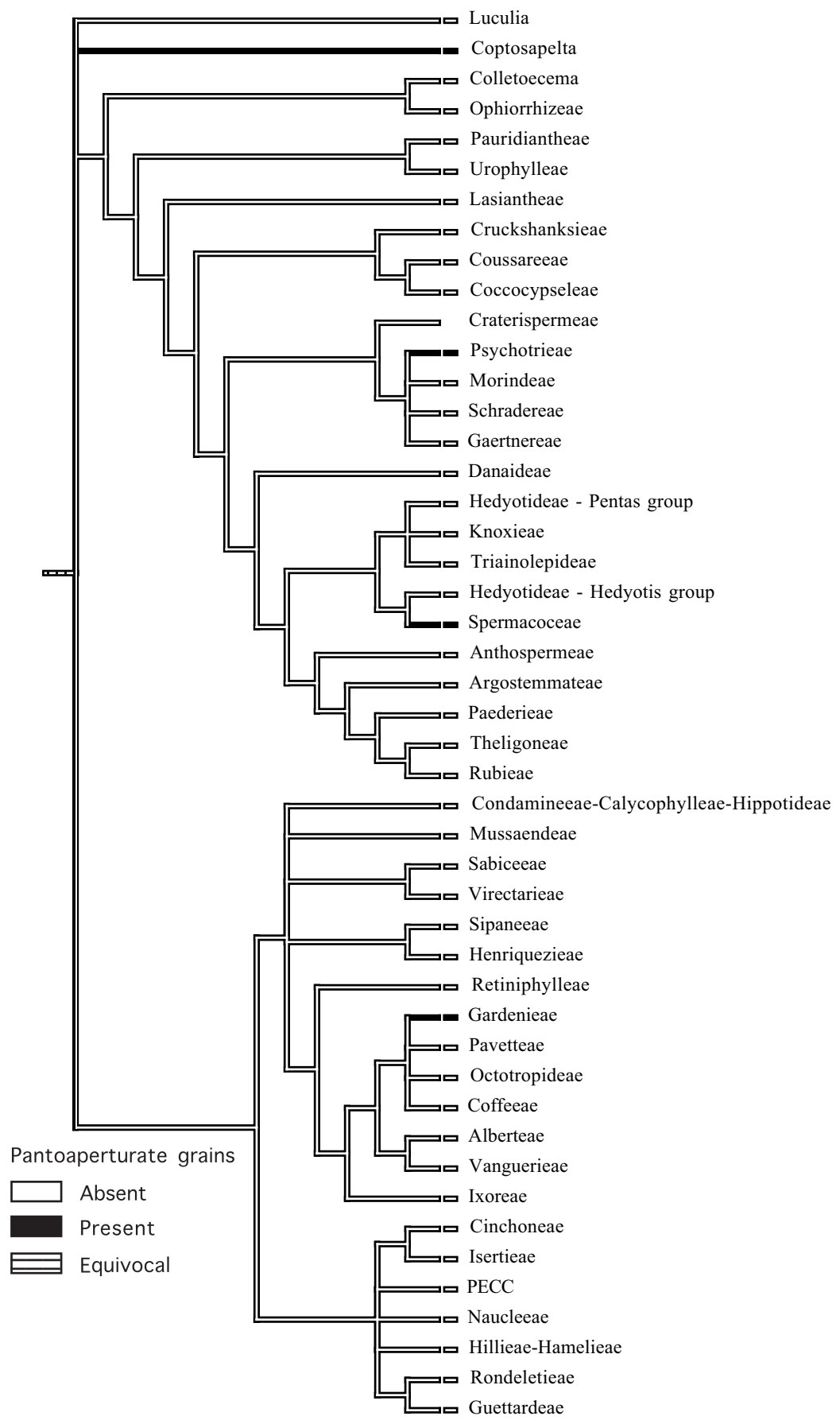

Fig. 60. Summary cladogram of Rubiaceae, indicating the taxa in which pantoaperturate pollen occurs. 


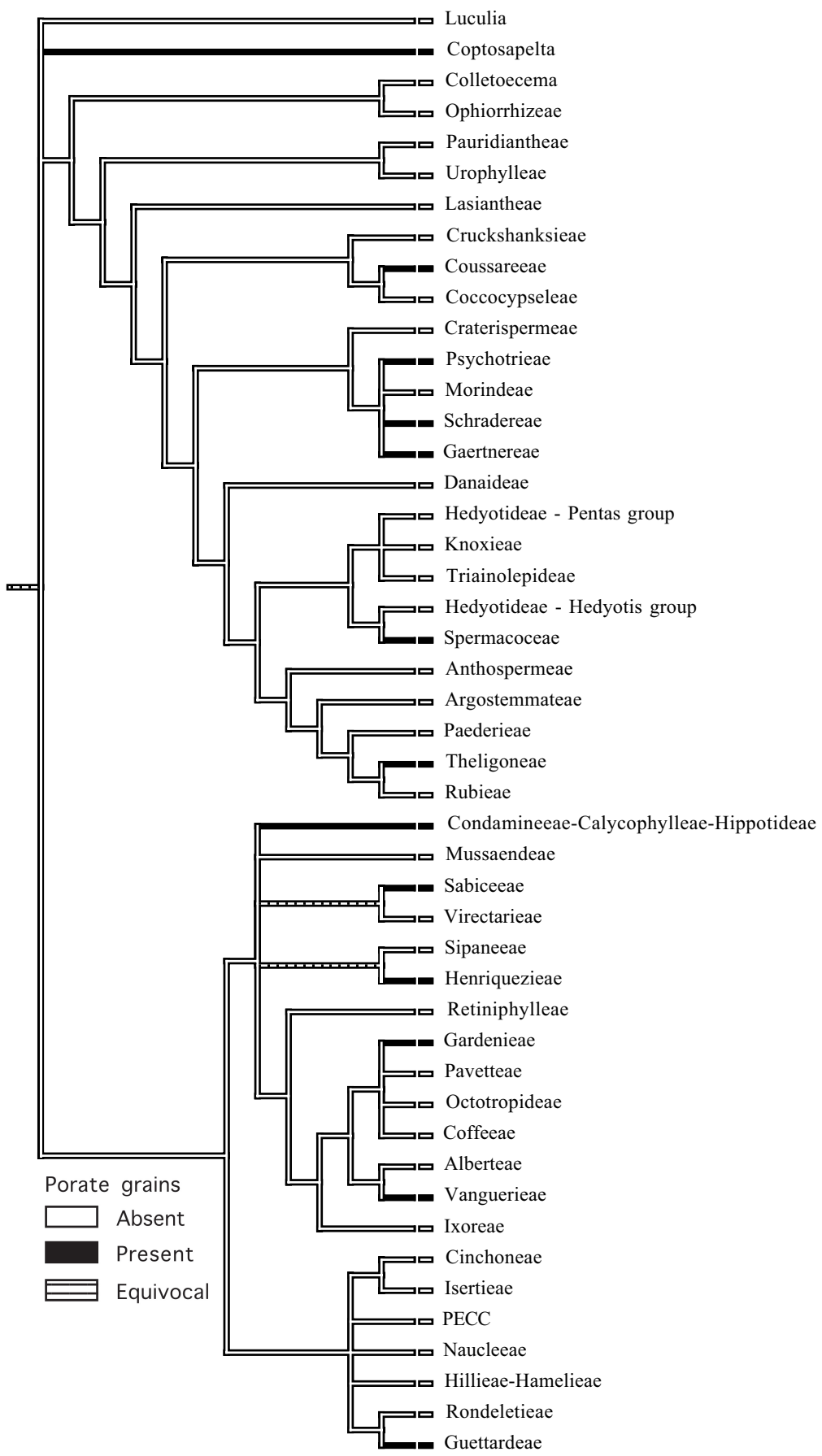

Fig. 61. Summary cladogram of Rubiaceae, indicating the taxa in which po(ro)rate pollen occurs. 
by very different pollen grains: Rubieae have pluricolpate grains; Paederieae, 3-colpate grains; and Theligoneae, pantoporate grains. Pollen grain size, pollen shape, or peculiarities of the sexine are rather diverse and do not unite these three tribes. The synapomorphy is found at the inside of the pollen grains. All members of this clade seem to lack a distinct endoaperture, a feature otherwise almost omnipresent in the subfamily Rubioideae.

In some cases the pollen type observed is not unique to a single tribe. Pollen morphology may then be useful in rejecting or supporting molecular phylogenies. This is, for example, the case for the extended tribe Coccocypseleae (cf. Piesschaert et al., 2000b). A macromolecular study by Andersson and Rova (1999) proposed a close relationship among the genera Coccocypselum P. Br., Hindsia Benh. ex Lindl., and Declieuxia Kunth., three genera that were never considered be close allies. Piesschaert et al. (2000b) demonstrated that pollen of the three genera is remarkably similar. The pollen grains are medium to very large, are invariably 3 -colporate, and feature a double reticulum. Although this pollen type is not unique to the tribe (it is also observed among genera from the tribe Spermacoceae s.1.), it does supply morphological support for a close relationship.

A few tribes are characterized not by a single pollen type but by a large number of pollen morphs. Pollen of the eurypalynous tribes is often not useful for delimiting the tribal boundaries but is rather useful at a lower taxonomic level (see below). Eurypalous tribes are Psychotrieae, Morindeae, Spermacoceae s.str., Coffeeae, Sabiceeae, and Gardenieae, as is the HedyotideaeHedyotis-group. In some of these tribes less-specialized pollen grains are found next to more derived types. Pollen morphology of tribes not cited above is less typical or often not adequately known to draw conclusions.

\section{Generic and Infrageneric Level}

In the eurypalynous tribes, different pollen types are observed. This pollen plasticity is not unique to Rubiaceae but is also recorded for genera of other angiosperm families (cf. Van Campo, 1976).

\section{a. Generic Level}

Persson (1993) studied in detail the pollen morphology of "Gardeniinae" (see Gardenieae in Table I). This subtribe comprises 64 genera, mainly trees, shrubs, and lianas. The eurypalynous character of the group is eye catching. Monads, tetrads, and polyads are observed; the pollen size ranges from very small to medium (rarely large); and the tectum is perforate, (micro)reticulate, foveolate, psilate, or rugulate. The pollen morphological variation within the genera turned out to be rather limited, however. Persson (1993: 581) wrote, "Contrary to the subtribe the majority of the genera are highly stenopalynous, the two neotropical genera Randia and Alibertia (A. Rich.) forming two striking exceptions." This situation agrees well with what was described by Dessein (2003) for the genera of Spermacoceae s.str., where Spermacoce forms the striking exception. Some other, higher taxa that contain stenopalynous genera are the tribe Morindeae (cf. Johansson, 1987a), the Hedyotideae-Pentas group (Dessein et al., 2000), and probably also the Hedyotideae-Hedyotis group.

\section{b. Subgeneric and Specific Level}

Pollen morphological data are sometimes useful in delimiting species within a genus; for example, in the pantropical genera Spermacoce and Psychotria. Johansson (1992) studied the pollen morphology of 168 species of Psychotria s.l. His study well illustrated the variation for 
almost each character, which resulted in the characterization of 22 pollen types. In conclusion he wrote, "Psychotria in a wide sense is very heterogeneous pollen morphologically and it is not possible to use pollen grain characteristics for the delimitation of the genus as now defined. ... Exine morphology presents powerful characters for distinguishing between species groups in Psychotria s.l. . . It is evident . . that pollen morphological analyses should form an integrated part of every future systematic investigation of the genus Psychotria s.l." (Johansson 1992: 29-30).

Pire (1996), Dessein et al. (2002a), and Dessein et al. (2005b) observed a similar wide variation in pollen characters in Spermacoce. In total almost 150 species $(>50 \%)$ of this genus have been studied pollen morphologically, and 20 different pollen types have been recognized. In many cases, species can be identified on the basis of their pollen grains only, and pollen was used to solve taxonomic debates from the past (Dessein et al., 2003). In many other genera of the Rubiaceae, pollen is not so variable but is still useful for supporting groups of related species.

\section{c. Infraspecific Variation}

In Rubiaceae, infraspecific pollen variation is frequently observed. Sometimes, variation can be linked with heterostyly or coincides with infraspecific taxa. The number of apertures is probably the most variable character at the species level. Many species have predominantly 3 colpi, but 4 or, more rarely, 5 colpi are sometimes observed. The pollen grains with an aberrant number of apertures are often present in low frequencies, but in some cases 3- and 4aperturate grains are observed in equal quantities (e.g., for some species of Pentas Benth.; Dessein et al., 2000). Pollen size is also variable at the species level, sometimes with pollen of different sizes in one anther, as in Ernodea (see the section on "Pollen Size," above).

The best-documented case of pollen polymorphy in Rubiaceae-i.e., plants having several kinds of palynomorphs - is observed in the genus Coffea. Chinnappa and Warner (1982) found that 13 species and varieties of Coffea s.l. are highly polymorphic. Coffea arabica L. beats the lot with 6 "distinct" pollen types, based on the number of colpi, aperture type (syncolporate or not), tectum peculiarities, and shape of the endoaperture. Some of these abnormal pollen types, however, were observed only in very low frequencies and may well represent malformed pollen grains. Stoffelen et al. (1997) considered the pollen polymorphism of Coffea an expression of a continuous variation within several characters. The occurrence of infraspecific plasticity certainly lowers the systematic value of pollen grains in some cases.

\section{B. SYSTEMATIC VALUE OF POLLEN DATA COMPARED WITH OTHER MORPHOLOGICAL CHARACTERS}

As illustrated above, certain pollen characters may be very plastic in one group and rather conserved in another. Hence, no overall systematic value can be assigned to these characters or character states, and their value should be assessed separately for each study group. This is very much in accordance with what is observed for most morphological characters within Rubiaceae. The "number and position of ovules in a locule" provides a good example. In former classification systems, much attention was paid to this character, and the subdivision into subfamilies by Hooker (1873) and Schumann (1891) was based on it. Even the much more polythetic system of Robbrecht (1988a) characterized one of the subfamilies (Antirheoideae) on the basis of the presence of a single pendulous ovule per locule, but molecular data completely reject the systematic value of this character at higher systematic levels. 
This does not mean, however, that (pollen) morphological characters are useless in the systematics of the family. Morphological characters are still useful, but at levels different from (usually lower than) those that have been acknowledged (see below).

\section{ORBICULES AND PHYLOGENY}

Our current knowledge of the presence and typology of orbicules within Rubiaceae is fragmentary. Only two subfamilies - Cinchonoideae s.str. and Ixoroideae s.1.- have been explored, by Huysmans et al. (1997) and by Vinckier et al. (2000), respectively. For Rubioideae, data on orbicules are available only for the tribe Rubieae and a few genera scattered all over the subfamily. Both Huysmans et al. (1997) and Vinckier et al. (2000) stated that tapetal orbicules can be useful taxonomic markers at the tribal level. In Ixoroideae s.l., for example, Vinckier et al. (2000) found that the tribes Coffeeae, Octotropideae, Ixoreae, and Pavetteae are characterized by specific orbicule types. The number of genera and species sampled in the studies available is very low, however, and more data are needed to prove that orbicule types really do coincide with tribal boundaries.

Another problem that needs to be addressed is the relationship among tapetum type, sexine ornamentation, and orbicule type. Pollen with supratectal spines often has echinate orbicules (type I) - e.g., in the PECC-complex (Huysmans et al., 1999) — whereas species with a smooth but perforate or microreticulate tectum often possess orbicules with perforations in their wall (Vinckier et al., 2000). According to Hesse (1986), these parallelisms are rooted in the homology of tapetum and sporogeneous tissue. The tapetum and the microspores contain homologous, nearly identical genetic information for the production, release, and accumulation of sporopollenin (Hesse, 1986; Pacini et al., 1985; Young et al., 1979). Studies of orbicule wall formation may clarify the underlying factors determining exine and orbicule wall patterning. Furthermore, orbicules are extracellular structures, independent of cytoplasmic control, as opposed to the pollen exine. These observations corroborate the idea proposed by Clément and Audran (1993a, 1993b) that orbicule wall development can represent a model for studying sporopollenin deposition.

The absence of orbicules in Rubieae, on the other hand, may merely indicate the presence of plasmodial tapeta in this tribe. This more evolved type of tapetum lost the potential to produce orbicules. At present, it is impossible to correctly interpret the absence of orbicules because so little is known about tapetum types in Rubiaceae (cf. Andronova,1984).

\section{CODING POLLEN CHARACTERS FOR CLADISTIC ANALYSES}

Pollen characters are no doubt an important source of phylogenetically informative characters. As a result, they are frequently incorporated into morphologic cladistic analyses. Nevertheless, most of the analyses that include pollen lack (profound) discussions of character and character state delimitations. The lack of discussions on these issues may result in undetected, inappropriate coding that may bias the results of the phylogenetic analysis or produce high levels of homoplasy, which can be used as argument for excluding pollen from future analyses. Most pollen characters have been proved to and are expected to have homoplasy, but this should not discourage researchers from incorporating them into cladistic analyses. The existence of homoplasy does not necessarily mean that the character does not contain a phylogenetic signal. In the previous sections we showed that some character states are useful in circumscribing higher taxonomic levels, even though they may have more than a single, independent origin. In the process of phylogenetic analyses, homoplasy means ignorance that can be caused either by inappropriate character or character state definitions and/or coding or by 
our inability to differentiate homologous and nonhomologous conditions. Worrying about homoplasy is meaningful only if it is so high that it no longer provides useful grouping information. Otherwise, homoplasy should be considered necessary for exercising reciprocal illumination and as a tool with which to conduct targeted further investigations. In the case of pollen, this often means completing our knowledge by studying the fine ultrastructure and ontogeny of the grains.

In this section we will provide suggestions about how to code some of the commonly used pollen characters and other possible characters not commonly incorporated into phylogenetic analyses. The utility and the way to code a character frequently depends on the taxonomic level (hierarchy) at which the analysis is being conducted. Our discussion emphasizes higher taxonomic levels - i.e., tribes and above — but we hope that it will also be a useful guide for studies below these levels, which may include additional characters.

Distinguishing continuous and discrete characters may be difficult, but is important in phylogenetic analyses because it affects the primary homology assessments. With respect to pollen characters, obviously continuous characters are pollen size, length of polar axis, and equatorial diameter, as well as ectoaperture length. Less obvious are the shape of the grains, which is dependent on the ratio of $\mathrm{P} / \mathrm{E}$, and the type of tectum discontinuities (perforate, microreticulate, foveolate, or reticulate), which depend on the size of the discontinuities. Several alternatives for coding continuous characters have been proposed, such as Farris (1990), Strait et al. (1996), or Swiderski et al. (1998), or Thiele (1993). Of these proposals, the one of Thiele (1993) has been implemented in the computer program Morphocode, <http://www.kuleuven.ac.be/bio/ $\mathrm{sys} / \mathrm{mc} />$. In this method a continuous character is treated as an ordered multistate character in which raw measurements are transformed into character states by using a simple algorithm. The method in fact weights the differences between the measurements. Other methods, including simple statistical tests (e.g., Luna \& Ochoterena, 2004), have been used. The application of a particular method to treat continuous characters depends, as in many other cases, on the case study and on the statistical properties of the data, and we recommend testing different methods by trial and error so that a reasonable amount of potential phylogenetic information is obtained by the groupings achieved.

Some of the characters that we discuss below can only be used in a few practical cases, because knowledge about them is generally lacking in many genera. Nevertheless, we include them in this section in the hope that the discussion below will stimulate more research on those topics.

Dispersal units (monads-tetrads-massulae) can be used as a potential source of phylogenetic information, but tetrad configuration (tetrahedral-uniplanar-decussate) does not seem to be reliable, because it may be variable even within a single individual. The characteristics of the apertures can be coded as several characters or as a few complex characters. Even though the latter option is widely used, we consider that it is not the most appropriate, because it results in a considerable reduction of potential phylogenetic information. One obvious condition to consider in phylogenetic analyses is the presence of apertures in different layers of the exine. Because most taxa have ectoaperturate pollen, this condition is implied when one codes the characteristics of that type of aperture. On the other hand, the presence of endo- and mesoapertures is not constant, so they should be coded as two independent characters. Regarding the ectoapertures, an obvious condition that appears to have phylogenetic content is their number. This is in fact a quantitative character, but within most of the taxa it is constant and at the same time variable among them. Therefore, we recommend using it as a simple numeric character, with as many states as the existing number of apertures. Nevertheless, in some cases, when the number of apertures exceeds 5, it may be sufficient to code them as "many" (e.g., 34-5-more than 5). Taxa with a variable number of apertures should be coded as (subset-) polymorphic, because coding these cases as different states will create groupings that do not 
necessarily reflect homology. The distribution of the ectoapertures can also be considered spread (pantoaperturate) or confined to the equator (zonoaperturate). The position of the ectoaperture with respect to the angles of the outline in polar view (angulaperturate-planaperturate) could also be incorporated in cladistic analyses. Nevertheless, this is a character that requires further attention, because it is seldom recognizable given the lack of angles in the common circular shape in polar view of Rubiaceae grains. It seems possible, however, that the relative position of both types of ectoapertures depends on the configuration of the tetrad. To explore this possibility, pollen ontogenetic studies should be undertaken to investigate whether the position of these two types of apertures is constant in the tetrad, thereby giving an indirect way to determine the character state even in pollen grains with a circular amb. One of the most obvious characters related to the ectoapertures is their shape (colpus-pore). Both conditions are normally easy to distinguish, but in Vanguerieae they seem to form a gradient. The presenceabsence of a prominently protruding thickening of the exine around an ectoaperture, most commonly around a pore (aspis), can also be coded.

The presence-absence of mesoapertures seems easy to define in theory, but in practice it can be problematic. This is because it depends on the degree of thinning, which is sometimes difficult to observe. Therefore, this character should be explored with caution.

Regarding the endoaperture, it is necessary to consider whether it is congruent with the ectoaperture (relative size of the endoaperture with respect to the ectoaperture: congruentnoncongruent) and its shape (pore-colpus-cingulum). As for the ectoapertures, the presenceabsence of a thickening of the nexine/endexine bordering an endoaperture, or following the outline of an ectoaperture (costa), can also be coded. In the latter case, sometimes it is possible to further specify the type of costa, depending on which aperture it is bordering (e.g., costa ectocolpi-costa endopri).

Several characters related to the exine can be included. The most obvious ones are the presence-absence of a tectum, columella layer, and free-standing bacula. In many cases these conditions are easy to recognize, but in some instances TEM observations may be required. The presence-absence of supratectal ornamentations is easy to recognize with SEM, but the definition of classes within this character (granules-microspines-spines) is problematic, because it corresponds to continuous variation. The reticulum of the exine can be simple or double, a character that is normally easy to code, but the nature of the double reticulum should be explored in more detail.

The ornamentation of the nexine can also be potentially informative, but it is a character that has been recorded only recently. To date, it seems possible to recognize different character states for the inner nexine (granular-endocracks-water drops-isolated patches), but it is possible that, as more information regarding this character is gathered, the distinction between the states will become fuzzy.

Orbicules also represent a potential source for several cladistically informative characters. Since they were first described, more researchers have paid attention to their presence-absence, but, as happens with several other morphological characters (e.g., raphides), it is not easy to use bibliographical references to code this character. This is mainly because absence is generally not reported. In order to have more confidence in the incorporation of this character in phylogenetic analyses, we encourage researchers to also report the absence of orbicules. If they are present, several characters can additionally be coded: the presentation of the orbicules (free-embedded); their shape (spiny-microruguate-smooth-folded-granular); the presenceabsence of ornamentation on their walls; the presence-absence of perforations in their walls; and the characteristics of the core (electron dense-lucent). Evidently, taxa that lack orbicules need to be coded as inapplicable for the other characters. 
Characters that would be interesting to include but are difficult to define and compare, given the current state of knowledge, are the presence-absence of protruding onci and pollen buds. Both structures are nonresistant to acetolysis and therefore in many cases have not been recorded, even though they may be frequent. In general appearance they may look similar, especially at the precursor states, but they can be unequivocally distinguished with the use of TEM.

Pollen dimorphism can be caused by several factors, so it requires special attention. In general, it is a difficult character to include in phylogenetic analyses, because it generally depends on sampling. For example, the most common cause for pollen dimorphism is heterostyly; the detection of two pollen-size modes depends on examination of both types of flowers (long and short style). If the sampling of pollen is specifically designed to cover this type of cases, it can be an interesting character to include in phylogenetic analyses. It is important to note that the cause of dimorphism (e.g., heterostyly) should not be included in the cladistic analysis at certain taxonomic levels, where it may be a completely dependent character.

Finally, we would like to suggest the exclusion of characters with intermediary conditions that make it difficult to define characters and character states. This is the case for: colpus ending and extensions of the endoaperture. Also, due to potential artifacts caused by acetolysis, we suggest excluding characters such as colpus membrane ornamentation and presenceabsence of operculum, even though they may contain a phylogenetic signal.

\section{Future Research}

Recently, enormous progress has been made in documenting the pollen morphology of Rubiaceae. Only now, by confronting the pollen data with the resulting phylogenies based on molecular data, can pollen evolution be inferred at all taxonomic levels. The present review of palynological literature on the family reveals the genera that were never studied and aims to stimulate further palynological exploration in Rubiaceae.

Apart from the need for pollen observations for the undocumented genera of Rubiaceae, many other pollen related topics deserve our attention. The relationship between pollen morphological traits and their ecological and/or functional role is in general and thus also in Rubiaceae largely underexplored. The possible link between pollinators and sexine ornamentation, habitat and apertural configuration, and flower morphology and pollen size also provide exciting research topics in several groups of Rubiaceae. A combined ontogenetic and evo-devo study in the eurypalynous genera such as Spermacoce may also provide new insights into the morphological diversity observed.

Another gap in our knowledge is the detailed development of the pollen grain wall and the orbicules. Only a few species have been investigated in this respect, and only two reports are based on ultrastructural observations (Mitriostigma: Hansson \& El-Ghazaly, 2000; Rondeletia: El-Ghazaly et al., 2001). Regarding the orbicules, our understanding of their presence/absence pattern and their possible function(s) could improve considerably if more (ultrastructural) data on tapetum types in Rubiaceae become available.

We would greatly appreciate your feedback on this review. With your assistance we will make the pollen database of Rubiaceae as complete as possible and keep it updated.

\section{Acknowledgments}

The authors wish to thank all former and present students at the Laboratory of Plant Systematics who studied Rubiaceae pollen and orbicules for their individual contributions to this review. Anja Vandeperre and Marcel Verhaegen are acknowledged for technical assistance. 
This study was supported by grants from the Research Council of the Catholic University of Leuven (OT/01/25) and F.W.O.-Vlaanderen (G.0268.04). Steven Dessein and Stefan Vinckier are postdoctoral fellows of the F.W.O.-Vlaanderen. Suzy Huysmans gratefully acknowledges I.W.T. and F.W.O.-Vlaanderen for the personal grants that made it possible to focus on Rubiaceae pollen and orbicules for eight years. Visits by Helga Ochoterena to the Laboratory of Plant Systematics were financially supported by the F.W.O.-Vlaanderen and the Coimbra Group.

\section{Literature Cited}

Adams, L. G., D. M. Bridson \& E. Robbrecht. 1987. The identity of Lasianthus graciliflorus Bailey (Rubiaceae). Kew Bull. 42: 209-214.

Aiello, A. 1979. A reexamination of Portlandia (Rubiaceae) and associated taxa. J. Arnold Arbor. 60: $38-126$.

Ali, S. J. \& E. Robbrecht. 1991. Remarks on the tropical Asian and Australian taxa included in Diplospora or Tricalysia (Rubiaceae-Ixoroideae-Gardenieae). Blumea 35: 279-305.

Anderson, W. R. 1972. A monograph of the genus Crusea (Rubiaceae). Mem. New York Bot. Gard. 22: $1-128$.

. 1973. A morphological hypothesis for the origin of heterostyly in the Rubiaceae. Taxon 22: 537542.

Andersson, L. 1993. Pollen characteristics of the tribes Calycophylleae, Cinchoneae, and Hillieae (Rubiaceae). Nordic J. Bot. 13: 405-417.

\& J. H. E. Rova. 1999. The rps 16 intron and the phylogeny of the Rubioideae (Rubiaceae). Pl. Syst. Evol. 214: 161-186.

Andreasen, K. \& B. Bremer. 2000. Combined phylogenetic analysis in the Rubiaceae-Ixoroideae: Morphology, nuclear and chloroplast DNA data. Amer. J. Bot. 87: 1731-1748.

, B. G. Baldwin \& B. Bremer. 1999. Phylogenetic utility of the nuclear rDNA ITS region in subfamily Ixoroideae (Rubiaceae): Comparisons with cpDNA $r b c \mathrm{~L}$ sequence data. Pl. Syst. Evol. 217: 119-135.

Andronova, N. N. 1984. The structure of the anther and pollen development in the Rubiaceae. Bot. Zhurn. 69: 43-54 (in Russian).

Baker, H. G. 1956. Pollen dimorphism in the Rubiaceae. Evolution 10: 23-31.

Bangoura, D. 1992. Beiträge zur Klärung der Gattungsabgrenzungsprobleme und Verwandtschaftsverhältnisse in der Tribus Pauridiantheae (Rubiaceae). Ph.D. diss., Univ. Wien, Vienna.

Barrett, S. C. H. 1992. Heterostylous genetic polymorphisms: Model systems for evolutionary analysis. Pp. 1-29 in S. C. H. Barrett (ed.), Evolution and function of heterostyly. Monographs on Theoretical and Applied Genetics, 15. Springer-Verlag, Berlin.

Behnke, H. D. 1975. Electronenmikroskopische Untersuchungen zur Frage der verwandtschaftlichen Beziehungen zwischen Theligonum und Rubiaceae: Feinbau der Siebellement-Plastiden und Anmerkungen zur Struktur der Pollenexine. Plant. Syst. Evol. 123: 317-326.

Bir Bahadur. 1963. Heterostylism in Oldenlandia umbellata L. J. Genet. 58: 429-439. . 1966. Heterostyly in Oldenlandia scopulorum. Bull. J. Genet. 59: 267-272.

. 1968a. Pollen dimorphism in three heterostyled Rubiaceae. Rev. Palaeobot. Palynol. 7: 233-239. . 1968b. Heterostyly in Rubiaceae: A review. Osmania Univ. J. Sci. [Golden Jubilee Vol.] 4: 207-238. . 1970. Heterostyly in Hedyotis nigricans (Lam.) Fosb. J. Genet. 60: 175-177.

\& N. Rama Swamy. 1993. Pollen exine dimorphism in ten heterostylous species. J. Palynol. 29: $77-88$.

Borhidi, A. 1982. Studies in Rondeletieae (Rubiaceae), III. The genera Rogiera and Arachnothryx. Acta Bot. Acad. Sci. Hung. 28: 65-71.

\& M. Fernández Zequeira. 1981a. Studies in Rondeletieae (Rubiaceae), I. Anew genus: Roigella. Acta Bot. Acad. Sci. Hung. 27: 309-312.

- $\&$ - 1981b. Studies in Rondeletieae (Rubiaceae), II. A new genus: Suberanthus. Acta Bot. Acad. Sci. Hung. 27: 313-316.

- \& _ 1983. Studies in Rondeletieae (Rubiaceae), V. Los límites del género Suberanthus. Acta Bot. Hung. 29: 29-34. 
\& M. Járai-Komlódi. 1983. Studies in Rondeletieae (Rubiaceae), IV. A new genus: Javorkaea. Acta Bot. Hung. 29: 13-27.

$\longrightarrow,-$ \& M. Moncada. 1980. Acunaeanthus, a new genus of Rubiaceae. Acta Bot. Acad. Sci. Hung. 26: 277-287.

Bosser, J. \& D. Lobreau-Callen. 1998. Landiopsis Capuron ex Bosser, genre nouveau de Rubiaceae de Madagascar. Adansonia, sér. 3, 20: 131-137.

Bremekamp, C. E. B. 1952. The African species of Oldenlandia L. sensu Hiern et K. Schumann. Verh. Kon. Ned. Akad. Wetensch., Afd. Natuurk., Tweede Sect., 48: 1-297.

- 1963. On pollen dimorphism in heterostylous Psychotrieae, especially in the genus Mapouria Aubl. Grana Palynol. 4: 53-63.

- 1966. Remarks on the position, the delimitation and the subdivision of the Rubiaceae. Acta Bot. Neerl. 15: 1-33.

Bremer, B. \& M. Thulin. 1998. Collapse of Isertieae, re-establishment of Mussaendeae, and a new genus of Sabiceeae (Rubiaceae): Phylogenetic relationships based on $r b c$ L data. Pl. Syst. Evol. 211: 71-92. \& J. F. Manen. 2000. Phylogeny and classification of the subfamily Rubioideae (Rubiaceae). Pl. Syst. Evol. 225: 43-72.

— , R. K. Jansen, B. Oxelman, M. Backlund, H. Lantz \& K. J. Kim. 1999. More characters or more taxa for a robust phylogeny: Case study from the coffee family (Rubiaceae). Syst. Biol. 48: 413-435.

Bridson, D. M. \& E. Robbrecht. 1985a. Validation of the African genus Hyperacanthus E. Mey. (Rubiaceae tribe Gardenieae). Kew Bull. 40: 273-286.

$-\&-1985$ b. Further notes on the tribe Pavetteae (Rubiaceae). Bull. Jard. Bot. Belg. 55: 83-115. , P. Gasson \& E. Robbrecht. 1980. Phellocalyx, a new tropical African genus in the Rubiaceae (Gardenieae). Kew Bull. 35: 315-321.

Buchner, R. \& C. Puff. 1993. The genus complex Danais-Schismatoclada-Payera (Rubiaceae): Character states, generic delimitation and taxonomic position. Bull. Mus. Natl. Hist. Nat., B, Adansonia 15: 23-74.

Cabral, E. L. \& N. M. Bacigalupo. 2001. Scandentia, nuevo género de Rubiaceae-Spermacoceae. Darwiniana 39: 29-41.

Chaw, S. M. \& S. P. Darwin. 1992. A systematic study of the paleotropical genus Antirhea (Rubiaceae: Guettardeae). Tulane Stud. Zool. Bot. 28: 25-118.

Chennaveeraiah, M. S. \& P. M. Shivakumar. 1983. Pollen bud formation and its role in Ophiorrhiza spp. Ann. Bot. 51: 449-452.

Chinnappa, C. C. \& B. G. Warner. 1981. Pollen morphology in the genus Coffea (Rubiaceae) and its taxonomic significance. Bot. J. Linn. Soc. 83: 221-236. $\boldsymbol{\&} \longrightarrow$ 1982. Pollen morphology in the genus Coffea (Rubiaceae), II. Pollen polymorphism. Grana 21: 29-37.

Clément, C. \& J.-C. Audran. 1993a. Orbicule wall surface characteristics in Lilium (Liliaceae). Grana 32: $348-353$.

$\longrightarrow$ - 1993b. Electron microscope evidence for a membrane around the core of the Ubisch body in Lilium (Liliaceae). Grana 32: 311-314.

Cortés-B., R. \& S. Huysmans. Submitted. A survey of pollen and orbicules morphology of Retiniphyllum (Rubiaceae-Ixorideae). Rev. Palaeobot. Palynol.

Darwin, S. P. 1976. The genus Lindenia (Rubiaceae). J. Arnold. Arbor. 57: 426-449.

- 1977. The genus Mastixiodendron (Rubiaceae). J. Arnold. Arbor. 58: 349-381. . 1979. A synopsis of the indigenous genera of Pacific Rubiaceae. Allertonia 2: 1-44.

—. 1980a. Notes on Airosperma (Rubiaceae), with a new species from Fiji. J. Arnold. Arbor. 61: 95-105. - 1980b. Habroneuron Standley, a little-known genus of Mexican Rubiaceae. Brittonia 32: 343-347. - 1993. A revision of Timonius subgenus Timonius (Rubiaceae: Guettardeae). Allertonia 7: 1-39. - 1994. Systematics of Timonius subgenus Abbottia (Rubiaceae: Guettardeae). Syst. Bot. Monogr. 42: $1-86$.

De Block, P. 1997. Biosystematic studies in the tribe Pavetteae (Rubiaceae-Ixoroideae). Ph.D. diss., Univ. Instelling Antwerpen, Antwerp.

- 1998. The African species of Ixora (Rubiaceae: Pavetteae). Opera Bot. Belg. 9: 1-218. 2003. Robbrechtia, a new Rubiaceae genus from Madagascar. Syst. Bot. 28: 145-156. 
\& E. Robbrecht. 1998. Pollen morphology of the Pavetteae (Rubiaceae, Ixoroideae) and its taxonomic significance. Grana 37: 260-275.

, J. Degreef \& E. Robbrecht. 2001 [2002]. Reinstatement of the Afro-Malagasy genus Coptosperma (Rubiaceae, Ixoroideae, Pavetteae). Syst. Geogr. Pl. 71: 455-492.

Delprete, P. G. 1999a. Rondeletieae (Rubiaceae). Part I. Fl. Neotrop. Monogr. 77: 1-226.

- 1999b. Riodocea (Rubiaceae, Gardenieae), a new genus from the Brazilian Atlantic forest. Brittonia 51: $15-23$.

Dessein, S. 2003. Systematic studies in the Spermacoceae (Rubiaceae). Ph.D. diss., Catholic Univ. of Leuven. - A. Scheltens, S. Huysmans, E. Robbrecht \& E. Smets. 2000. Pollen morphological survey of Pentas (Rubiaceae-Rubioideae) and its closest allies. Rev. Palaeobot. Palynol. 112: 189-205.

_ S. Jansen, S. Huysmans, E. Robbrecht \& E. Smets. 2001a. A morphological and anatomical survey of Virectaria (African Rubiaceae), with a discussion of its taxonomic position. Bot. J. Linn. Soc. 137: 1-29.

— L. Andersson, E. Robbrecht \& E. Smets. 2001b. Hekistocarpa (Rubiaceae): A member of an emended tribe Virectarieae. Pl. Syst. Evol. 229: 59-78.

, S. Huysmans, E. Robbrecht \& E. Smets. 2002a. Pollen of African Spermacoce species (Rubiaceae). Grana 41: 69-89.

— S. Jansen, E. Robbrecht \& E. Smets. 2002b [2004]. A new species of Spermacoce (Rubiaceae) from the Manika high plateau (Katanga; R. D. Congo). Nordic J. Bot. 22: 513-523.

, S. Ntore, E. Robbrecht \& E. Smets. 2003. Pollen and seeds reveal that Spermacoce thymoidea s. lat. (African Rubiaceae, Spermacoceae) represents three endemic or disjunct species from the Zambezian high plateaus. Syst. Bot. 28: 130-144.

— L. Andersson, K. Geuten, E. Smets \& E. Robbrecht. 2005a. Gomphocalyx and Phylohydrax (Rubiaceae): Sister taxa excluded from the Spermacoceae s.s., featuring a remarkable case of convergent evolution. Taxon 54: 91-107.

, R. Harwood, S. Smets \& E. Robbrecht. 2005b. Pollen of the Spermacoce species from the Northern Territory of Australia: Morphology and taxonomic significance. Austral. Syst. Bot. 18: $367-382$.

D'hondt, C. 2002. Pollen- en orbiculemorfologie van Hillieae (Rubiaceae). Ph.D. diss., Catholic Univ. of Leuven.

, P. Schols, S. Huysmans \& E. Smets. 2004. Systematic relevance of pollen and orbicule characters in the tribe Hillieae (Rubiaceae). Bot. J. Linn. Soc. 146: 303-321.

Di Maio, F. R. 1996 [1998]. Revisão taxonomica de genero Hindsia Bentham (Rubiaceae, Hedyotideae). Arch. Jar. Bot. Rio de Janeiro 34: 51-92.

El-Ghazaly, G. \& S. Huysmans. 2001. Re-evaluation of a neglected layer in pollen wall development with comments on its evolution. Grana 40: 3-16. J. Bot. 88: 14-30.

Erdtman, G. 1971. Pollen morphology and plant taxonomy-Angiosperms. An Introduction to Palynology, I. Hafner Publishing, New York.

Es, K. 1999. Geophila (Psychotrieae, Rubiaceae): Revisie van de neotropische taxa. Licentiate thesis, Catholic Univ. of Leuven.

Farooq, M. \& M. Inamuddin. 1969. The embryology of Oldenlandia nudicaulis Roth. J. Indian Bot. Soc. 48: 166-173.

Farris, S. S. 1990. Phenetics in camouflage. Cladistics 6: 91-100.

Groeninckx, I. 2005. Zoektocht naar de taxonomische positie van Mitrasacmopsis (Rubiaceae) op basis van moleculaire en morfologische data. Licentiate thesis, Catholic Univ. of Leuven.

Gustafsson, C. G. R. 1998. The neotropical Rosenbergiodendron (Rubiaceae, Gardenieae). Brittonia 50: $452-466$.

\& C. Persson. 2002. Phylogenetic relationships among species of the neotropical genus Randia (Rubiaceae, Gardenieae) inferred from molecular and morphological data. Taxon 51: 661-674.

Hansson, T. \& G. El-Ghazaly. 2000. Development and cytochemistry of pollen and tapetum in Mitriostigma axillare (Rubiaceae). Grana 39: 65-89.

Havard, A. \& B. Verdcourt. 1987. A pollen survey of Tapiphyllum (Rubiaceae-Vanguerieae). Kew Bull. 42: 605-609. 
Hesse, M. 1986. Orbicules and the ektexine are homologous sporopollenin concretions in Spermatophyta. Pl. Syst. Evol. 153: 37-48.

Hooker, J. D. 1873. Ordo LXXXIV. Rubiaceae. Pp. 7-151 in G. Bentham \& J. D. Hooker (eds.), Genera plantarum ad exemplaria imprimis in herbariis kewensibus servata defirmata. London.

Huang, T. C. 1972. Pollen flora of Taiwan, VI. National Taiwan Univ., Botany Dept. Press, Taipei.

Huxley, C. R. \& M. H. P. Jebb. 1993. The tuberous epiphytes of the Rubiaceae, 5. A revision of Myrmecodia. Blumea 37: 271-334.

Huysmans, S. 1993. De pollenmorfologie van de Coptosapelteae (Rubiaceae-Cinchonoideae). Licentiate thesis, Catholic Univ. of Leuven.

- 1998. Palynology of the Cinchonoideae (Rubiaceae): Morphology and development of pollen and orbicules. Ph.D. diss., Catholic Univ. of Leuven.

, E. Robbrecht \& E. Smets. 1994. Are the genera Hallea and Mitragyna (RubiaceaeCoptosapelteae) pollen morphologically distinct? Blumea 39: 321-340.

— G. El-Ghazaly, S. Nilsson \& E. Smets. 1997. Systematic value of tapetal orbicules: A preliminary survey of the Cinchonoideae (Rubiaceae). Canad. J. Bot. 75: 815-826.

_ E. Robbrecht \& E. Smets. 1998a. A collapsed tribe revisited: Pollen morphology of the Isertieae (Cinchonoideae-Rubiaceae). Rev. Palaeobot. Palynol. 104: 85-113.

— G. El-Ghazaly \& E. Smets. 1998b. Orbicules in Angiosperms: Morphology, function, distribution, and relation with tapetum types. Bot. Rev. (Lancaster) 64: 240-272.

— E. Robbrecht, P. Delprete \& E. Smets. 1999. Pollen morphological support for the CatesbaeeaeChiococceae-Exostema-complex (Rubiaceae). Grana 38: 325-338.

, G. El-Ghazaly \& E. Smets. 2000. Orbicules: Still a well hidden secret of the anther. Pp. 201212 in B. Nordenstam, G. El-Ghazaly \& M. Kassas (eds.), Plant systematics for the $21^{\text {st }}$ century. Wenner-Gren International Series, 77. Portland Press, London.

— , S. Dessein, E. Smets \& E. Robbrecht. 2003. Pollen morphology of NW European representatives confirms monophyly of Rubieae (Rubiaceae). Rev. Palaeobot. Palynol. 127: 219-240.

Igersheim, A. 1989. Beiträge zur Klärung der Gattungsabgrenzung-probleme innerhalb der Rubiaceae Vanguerieae. Ph.D. diss., Botanical Institute, Vienna.

- 1991. Palynological investigations of Paederia L. (Rubiaceae-Paederieae). Pp. 135-149 in C. Puff (ed.), The genus Paederia L. (Rubiaceae-Paederieae): A multidisciplinary study. Opera Bot. Belg., 3. National Botanic Garden of Belgium, Meise.

. 1993a. The character states of the Caribbean monotypic endemic Strumpfia (Rubiaceae). Nordic J. Bot. 13: 545-559.

. 1993b. The palynology of the genus Rondeletia L. (Rubiaceae-Cinchonoideae-Rondeletieae). Grana 32: 321-326.

\& M. Weber. 1993 [1994]. "Pollen bud" formation in Ophiorrhiza (Rubiaceae). Pp. 51-59 in

E. Robbrecht (ed.), Advances in Rubiaceae Macrosystematics. Opera Bot. Belg., 6. National Botanic Garden of Belgium, Meise.

Jansen, S. 1994. Een houtanatomische en palynologische studie van Psychotrieae (Rubiaceae-Rubioideae). Licentiate thesis, Catholic Univ. of Leuven.

, E. Robbrecht \& E. Smets. 1996a. The systematic value of endexine ornamentation in some Psychotrieae pollen (Rubiaceae-Rubioideae). Grana 35: 129-137.

$\longrightarrow$ - H. Beeckman \& E. Smets. 1996b. Gaertnera and Pagamea: Genera within the Psychotrieae or constituting the tribe Gaertnereae? A wood anatomical and palynological approach. Bot. Acta 109: 466-476.

Johansson, J. T. 1987a. Pollen morphology of the tribe Morindeae (Rubiaceae). Grana 26: 134-150. . 1987b. Revision of the genus Prismatomeris Thw. (Rubiaceae, Morindeae). Opera Bot. 94: 1-62. - 1992. Pollen morphology in Psychotria (Rubiaceae, Rubioideae, Psychotrieae) and its taxonomic significance: A preliminary survey. Opera Bot. 115: 1-71.

\& K. M. Wong. 1988. The identity of Prismatomeris subsessilis King \& Gamble (Rubiaceae, Rubioideae). Blumea 33: 351-356.

Jung-Mendaçolli, S. L. 1984. Contribuição ao estudo palinológico das Rubiaceae. Ph.D. diss., Univ. of São Paulo.

- \& T. S. Melhem. 1994. Flora polinica da reserva do parque estadual das fontes do Ipiranga (São Paulo, Brasil). Hoehnea 21: 131-155. 
— $\&$. 1995. Grãos de polen de especies heterostilicas de Rubiaceae (Pollen grains of heterostylous Rubiaceae). Revista Brasil. Bot. 18: 61-93.

Keddam-Malplanche, M. 1980. Etude palynologique comparative des espèces lianescentes dans les genres Sherbournia et Porterandia (Rubiacées-Gardéniées). Adansonia, sér. 2, 19: 429-434.

- 1985. Le pollen et les stomates des Gardeniées (Rubiacée) du Gabon. Morphologie et tendances évolutives. Mém. Mus. Nation. Hist. Nat. Nouv. Ser., Sér. B, 29. Paris.

Kirkbride, J. H., Jr. 1979. Revision of the genus Psyllocarpus (Rubiaceae). Smithsonian Contr. Bot. 41: $1-32$.

Lecuona Neumann, R. M., I. La Serna Ramos, B. Mendes Pérez \& W. Wildpret de la Torre. 1987. Contribución al estudio palinológico de la flora endémica macronesica. Pollen \& Spores 29: 359-390.

Lens, F., S. Jansen, S. Huysmans, E. Robbrecht \& E. Smets. 2000. Pollen morphological variation in Vanguerieae (Ixoroideae-Rubiaceae). Grana 39: 1-13.

Léonard, J. 1984. Contribution à la connaissance de la flore de l'Iran, VI. Le "complexe Gaillionia A. Rich. ex DC." (Rubiaceae). Bull. Jard. Bot. Belg. 54: 493-497.

Leroy, J. F. 1974. Recherches sur les Rubiacees de Madagascar: Les genres Mantalania et Pseudomantalania (Gardeniées). Adansonia 14: 29-52.

Lewis, W. H. 1965a. Cytopalynological study of African Hedyotideae (Rubiaceae). Ann. Missouri Bot. Gard. 52: 182-211.

- 1965b. Pollen morphology and evolution in Hedyotis subgenus Edrisia (Rubiaceae). Amer. J. Bot. 52: $257-264$.

- 1966. The Asian genus Neanotis nomen novum (Anotis) and allied taxa in the Americas (Rubiaceae). Ann. Missouri Bot. Gard. 53: 32-46.

Lobreau-Callen, D. 1978. L'aperture composée des Rubiaceae. Annales Mines Belg. 2: 167-173.

Lorence, D. H. 1986. Glossostipula (Rubiaceae), a new genus from Mexico and Guatemala. Candollea 41: 453-461.

Luna, I. \& H. Ochoterena. 2004. Phylogenetic relationships of the genera of Theaceae based on morphology. Cladistics 20: 223-270.

Mabberley, D. J. 1997. The plant-book: A portable dictionary of the vascular plants. Ed. 2. Cambridge Univ. Press, Cambridge.

Malplanche, M. 1971. Etude palynologique de trois genres de Rubiacées—Gardéniées d'Afrique. Adansonia, sér. 2, 11: 343-355.

Mathew, P. M. \& O. Philip. 1983. Studies in the pollen morphology of South Indian Rubiaceae. Vol. 10 of P. K. K. Nair (ed.), Advances in pollen-spore research. New Delhi: Today and Tomorrow's Printers. $\boldsymbol{\&}-$. 1987. Developmental and systematic significance of pollen bud formation in Ophiorrhiza Linn. New Botanist 14: 47-54.

McDowell, T. 1996. Syringantha coulteri (Hooker f.) T. McDowell, a new combination, and remarks on the relationships of the monotypic Mexican genus Syringantha Standley (Rubiaceae). Novon 6: 273-279.

Motley T. J., K. J. Wurdack \& P. G. Delprete. 2005. Molecular systematics of the CatesbaeeaeChiococceae complex (Rubiaceae): Flower and fruit evolution and biogeographic implications. Amer. J. Bot. 92: 316-329.

Muller, J. 1981. Fossil pollen records of extant angiosperms. Bot. Rev. (Lancaster) 47: 1-142.

Naiki, A. \& H. Nagamasu. 2003. Distyly and pollen dimorphism in Damnacanthus (Rubiaceae). J. Pl. Res. 105-113.

Negrón-Ortiz, V. 1996. Reproductive biology of Ernodea (Rubiaceae-Spermacoceae) in the Bahamas and Puerto Rico. Pp. 403-412 in E. Robbrecht, C. Puff \& E. Smets (eds.), Second Int. Rubiaceae Conf., Proceedings. Opera Bot. Belg., 7. National Botanic Garden Belgium, Meise.

Nilsson, S. \& J. Praglowski. 1992. Erdtman's handbook of palynology. Ed. 2. Munksgaard, Copenhagen.

Ntore, S. 2004. Contribution à la connaissance systématique du genre afrotropical Pauridiantha (Rubiaceae). Ph.D. diss., Catholic Univ. of Leuven.

, P. De Block, S. Huysmans, E. Robbrecht \& S. Dessein. 2003. Two new species from Gabon show the need to reduce Commitheca to the synonymy of Pauridiantha (Rubiaceae, Pauridiantheae). Bot. J. Linn. Soc. 141: 105-117.

Ochoterena, H. 2000. Systematics of Hintonia Bullock and the Portlandia complex (Rubiaceae). Ph.D. diss., Cornell Univ. 
Pacini, E. \& G. G. Franchi. 1993. Role of the tapetum in pollen and spore dispersal. Pl. Syst. Evol., Suppl. 7: 1-11.

, G. G. Franchi \& M. Hesse. 1985. The tapetum: Its form, function and possible phylogeny in embryophyta. Pl. Syst. Evol. 149: 155-185.

Pailler, T. \& J. D. Thompson. 1997. Distyly and variation in heteromorphic incompatibility in Gaertnera vaginata (Rubiaceae) endemic to La Réunion Island. Amer. J. Bot. 84: 315-327.

Persson, C. 1993. Pollen morphology of the Gardenieae-Gardeniinae (Rubiaceae). Nordic J. Bot. 13: $561-582$.

Philip, O. \& P. M. Mathew. 1975. Cytology of exceptional development of the male gametophyte in Ophiorrhiza mungos. Canad. J. Bot. 53: 2032-2037.

Piesschaert, F. 2001. Carpology and pollen morphology of the Psychotrieae (Rubiaceae-Rubioideae): Towards a new tribal and generic delimitation. Ph.D. diss., Catholic Univ. of Leuven.

— S. Jansen, S. Huysmans, E. Smets \& E. Robbrecht. 1999a. Chassalia petitiana (RubiaceaePsychotrieae), an overlooked epiphytic species hidden in the African canopy. Syst. Bot. 24: 315-322.

—, E. Robbrecht, A. D. Poulsen \& E. Smets. 1999b. Pyrene and pollen observations in the pantropical genus Geophila (Rubiaceae-Psychotrieae). Nordic J. Bot. 19: 93-100.

, — \& E. Smets. 1999c. Chassalia subcordatifolia, a new combination in African Rubiaceae (Rubioideae, Psychotrieae). Syst. Geogr. Pl. 69: 189-194.

—, L. Andersson, S. Jansen, S. Dessein, E. Robbrecht \& E. Smets. 2000a. Searching for the taxonomic position of the African genus Colletoecema (Rubiaceae): Morphology and anatomy compared to an rps 16-intron analysis of the Rubioideae. Canad. J. Bot. 78: 288-304.

— S. Huysmans, I. Jaimes, E. Robbrecht \& E. Smets. 2000b. Morphological evidence for an extended tribe Coccocypseleae (Rubiaceae-Rubioideae). Pl. Biol. 2: 536-546.

— , S. Jansen, I. Jaimes, E. Robbrecht \& E. Smets. 2001. Morphology, anatomy, and taxonomic position of Pagameopsis (Rubiaceae-Rubioideae). Brittonia 53: 490-504.

Pire, S. M. 1996. Palynological study of American species of Borreria (Rubiaceae-Spermacoceae). Pp. 416-423 in E. Robbrecht, C. Puff \& E. Smets (eds.), Second Int. Rubiaceae Conf., Proceedings. Opera Bot. Belg., 7. National Botanic Garden Belgium, Meise.

- 1997a. Género Galianthe subg. Ebelia (Rubiaceae: Spermacoceae): Estudio palinológico. Ann. Missouri Bot. Gard. 84: 878-887.

- 1997b. The pollen of Brazilian species of Richardia L. (Rubiaceae-Spermacoceae). Rev. Univ. Guarulhos, Geosiências II Sp. Vol.: 184-191.

- \& E. L. Cabral. 1992. El valor del polen en la revalidación de Galianthe (SpermacoceaeRubiaceae). Darwiniana 31: 1-10.

Puff, C. 1986a. A biosystematic study of the African and Madagascan Rubiaceae. Anthospermae. SpringerVerlag, Vienna

. 1986b. Phylohydrax (Rubiaceae-Spermacoceae) - A new genus to accommodate the African and Madagascan "Hydrophylax" species. Pl. Syst. Evol. 154, 343-366.

- 1988. Observations on Carphalea Juss. (Rubiaceae, Hedyotideae), with particular reference to the Madagascan taxa and its taxonomic position. Bull. Jard. Bot. Belg. 58: 271-323.

- 1989. The affinities and relationships of the Japanese endemic Pseudopyxis (Rubiaceae: Paederieae). Pl. Spec. Biol. 4: 145-155.

\& R. Buchner. 1998. Lecananthus and Leucocodon, two genera to be added to the tribe Schradereae (Rubiaceae). Blumea 43: 265-286.

\& A. Igersheim. 1994a. The character states and taxonomic position of Metabolos Bl. (syn. Allaeophania Thw.) (Rubiaceae). Bull. Jard. Bot. Belg. 63: 241-262.

\& $\quad$ 1994b. The character states of Mussaendopsis Baill. (Rubiaceae-Coptosapelteae). Flora 189: 161-178.

\& E. Robbrecht. 1988. The taxonomic position of the Australian endemic Durringtonia (Rubiaceae). Austral. Syst. Bot. 1: 191-197.

- \& 1989. A survey of the Knoxieae (Rubiaceae-Antirheoideae). Bot. Jahrb. Syst. 110: $511-558$.

\& U. Rohrhofer. 1993 [1994]. The character states and taxonomic position of the monotypic mangrove genus Scyphiphora (Rubiaceae). Pp. 143-172 in E. Robbrecht (ed.), Advances in Rubiaceae macrosystematics. Opera Bot. Belg., 6. National Botanic Garden of Belgium, Meise. 
E. Robbrecht \& V. Randrianasolo. 1984. Observations on the SE African-Madagscan genus Alberta and its ally Nematostylis (Rubiaceae, Alberteae), with a survey of the species and a discussion of the taxonomic position. Bull. Jard. Bot. Belg. 54: 293-366.

—, L. Andersson, U. Rohrhofer \& A. Igersheim. 1993a. The tribe Schradereae (Rubiaceae) reexamined. Bot. Jahrb. Syst. 114: 449-479.

— A. Igersheim \& U. Rohrhofer. 1993b. Pseudomussaenda and Schizomussaenda (Rubiaceae): Close allies of Mussaenda. Bull. Jard. Bot. Belg. 62: 35-68.

—, R. Buchner \& A. Igersheim. 1996. Dichilanthe, an unusual Asiatic Rubiaceae with "Lonicera flowers" and "dipterocarp fruits." Nordic J. Bot. 16:145-164.

Punt, W., S. Blackmore, S. Nilsson \& A. Le Thomas. 1994. Glossary of pollen and spore terminology. LPP Foundation, Utrecht. (Updated online version: <http://www.bio.uu.nl/ palaeo/glossary /index.htm>.)

Puttock, C. F. 1992. Systematics of the Australian Gardenieae (Rubiaceae). Ph.D. diss., Univ. of New South Wales.

Ramam, S. S. 1954. Gametogenesis and fertilization of Stephegyne parviflora Korth. Agra Univ. J. Res., Sci. 3: $243-348$.

Razafimandimbison, S. G. \& B. Bremer. 2001 [2002]. Tribal delimitation of Naucleeae (Cinchonoideae, Rubiaceae): Inference from molecular and morphological data. Syst. Geogr. Pl. 71: 515-538.

Reitsma, T. 1969. Size modifications of recent pollen grains under different treatments. Rev. Palaeobot. Palynol. 9: 175-202.

Robbrecht, E. 1977. The tropical African genus Hymenocoleus (Rubiaceae-Psychotrieae): Additions. Bull. Jard. Bot. Belg. 47: 3-29.

- 1978a. Sericanthe, a new African genus of Rubiaceae (Coffeeae). Bull. Jard. Bot. Belgique 48: 3-78.

- 1978b. Some observations in Preussiodora Keay (African Rubiaceae, Gardenieae). Bull. Soc. Roy. Bot. Belgique 111: 3-9.

- 1979. The African genus Tricalysia A. Rich. (Rubiaceae-Coffeeae), 1. A revision of the species of subgenus Empogona. Bull. Jard. Bot. Belg. 49: 239-360.

. 1980. Bijdragen tot de classificatie van de Ixoroideae en tot de revisie van Tricalysia s.l. (Rubiaceae). Ph.D. diss., Univ. Gent.

-1981a. Studies in tropical African Rubiaceae, I. 1. A new species of Tricalysia subgenus Empogona from Gabon. 2. The position of "Tricalysia auriculata" and "Neorosea adamii." 3. A new species of Batopedina (Hedyotideae) from Shaba. 4. The distribution of Batopedina and Parapentas. Bull. Jard. Bot. Belg. 51: 165-189.

- 1981b. Studies in tropical African Rubiaceae, II. 5. A survey of Argocoffeopsis. 6. A revision of Calycosiphonia. Bull. Jard. Bot. Belg. 51: 359-378.

- 1982a. The African genus Tricalysia A. Rich. (Rubiaceae-Coffeeae), 2. Ephedranthera, a new section of subgenus Tricalysia. Bull. Jard. Bot. Belg. 52: 311-339.

- 1982b. Pollen morphology of the tribes Anthospermeae and Paederieae (Rubiaceae) in relation to taxonomy. Bull. Jard. Bot. Belg. 52: 349-366.

- 1983. The African genus Tricalysia A. Rich. (Rubiaceae), 3. Probletostemon revived as a section for subgenus Tricalysia. Bull. Jard. Bot. Belg. 53: 299-320.

. 1984. The delimitation and taxonomic position of the tropical African genera Leptactina and Dictyandra (Rubiaceae). Pl. Syst. Evol. 145: 105-118.

. 1985. Further observations on the pollen morphology of the South African genus Carpacoce (Rubiaceae-Anthospermeae). Rev. Palaeobot. Palynol. 45: 361-371.

- 1987. The African genus Tricalysia A. Rich. (Rubiaceae), 4. A revision of the species of section Tricalysia. Bull. Jard. Bot. Belg. 57: 39-208.

- 1988a. Tropical woody Rubiaceae: Characteristic features and progressions: Contributions to a new subfamilial classification. Opera Bot. Belg., 1. National Botanic Garden of Belgium, Meise.

. 1988b. Studies in tropical African Rubiaceae, 13. Petitiocodon, a new genus to accommodate Didymosalpinx parviflora (Gardenieae-Diplosporinae). Bull. Jard. Bot. Belg. 58: 109-120.

_. 1993 [1994]. Supplement to the 1988 outline of the classification of the Rubiaceae. Index to genera. Pp. 173-196 in E. Robbrecht (ed.), Advances in Rubiaceae macrosystematics. Opera Bot. Belg., 6. National Botanic Garden of Belgium, Meise. 
\& D. M. Bridson. 1984. The taxonomic position of the East African genus Cladoceras (Rubiaceae). Bull. Soc. Roy. Bot. Belgique 117: 247-251.

\& C. Puff. 1981. Mericocalyx Bamps, synonymous with Otiophora Zucc. (Rubiaceae). Bull. Jard. Bot. Nat. Belg. 51: 143-151.

- $\&$ - 1986. A survey of the Gardenieae and related tribes. Bot. Jahrb. Syst. 108: 63-138.

,$--\&$ A. Igersheim. 1991. Evidence for the close alliance between Mitchella and Damnacanthus, with comments on the campylotropy in the Rubiaceae and the circumscription of the Morindeae. Blumea 35: 307-345.

-, U. Rohrhofer \& C. Puff. 1993 [1994]. A survey of Bertiera (Rubiaceae), including a discussion of its taxonomic position. Pp. 101-141 in E. Robbrecht (ed.), Advances in Rubiaceae macrosystematics. Opera Bot. Belg., 6. National Botanic Garden of Belgium, Meise.

— S. Huysmans \& E. Figueiredo. 1996. The generic status of Oxyanthus gossweileri (Rubiaceae) in Angola. S. African J. Bot. 62: 17-22.

Rogers, G. K. 1984. Gleasonia, Henriquezia, and Platycarpum (Rubiaceae). Fl. Neotrop. Monogr. 39: $1-135$.

Rova, J. 1999. The Condamineeae Rondeletieae Sipaneeae complex (Rubiaceae). Ph.D. diss., Univ. Göteborg.

\& L. Andersson. 1995. A reevaluation of the tribes Hippotideae and Tammsieae (Rubiaceae). Nordic J. Bot. 15: 269-284.

- P. G. Delprete, L. Andersson \& V. A. Albert. 2002. A trnL-F cpDNA sequence study of the Condamineeae-Rondeletieae-Sipaneeae complex with implications on the phylogeny of the Rubiaceae. Am. J. Bot. 89: 145-159.

Rutishauser, R., L. P. Ronse Decraene, E. Smets \& I. Mendoza-Heuer. 1998. Theligonum cynocrambe: Developmental morphology of a peculiar rubiaceous herb. Pl. Syst. Evol. 210: 1-24.

Scheltens, A. 1998. Pollenmorfologische studie van de Afrikaanse Hedyotideae (Rubiaceae). Licentiate thesis, Catholic Univ. of Leuven.

Schumann, K. 1891. Rubiaceae. Pp. 1-156 in A. Engler \& K. Prantl (eds.), Die natürlichen Pflanzenfamilien. Engelmann, Leipzig.

Sotolongo Molina, L., M. Fernández Zequeira \& P. Herrera Oliver. 2002. Pollen morphology of some Cuban Guettarda species (Rubiaceae: Guettardeae). Grana 41: 142-148.

Stoffelen, P., E. Robbrecht \& E. Smets. 1997. Pollen morphology of Coffea and Psilanthus (RubiaceaeCoffeeae), mainly from Africa. Grana 36: 313-327.

Strait, D. S., M. A. Moniz \& P. T. Strait. 1996. Finite mixture coding: A new approach to coding continuous characters. Syst. Biol. 45: 67-78.

Swiderski, D. L., M. L. Zelditch \& W. L. Fink. 1998. Why morphometrics is not special: Coding quantitative data for phylogenetic analyses. Syst. Biol. 47: 508-519.

Tange, C. 1994. Neomussaenda (Rubiaceae), a new genus from Borneo. Nordic J. Bot. 14: 495-500.

. 1995. The identity of Siderobombyx and a new species of Xanthophytum (Rubiaceae). Nordic J. Bot. $575-581$.

- 1996a. Studies in SE Asiatic Rondeletieae, I: The West Malaysian endemic genus Aleisanthia (Rubiaceae). Nordic J. Bot. 16: 571-578.

. 1996b. Studies in SE Asiatic Rondeletieae, II: Aleisanthiopsis (Rubiaceae), a new genus from Borneo. Nordic J. Bot. 16: 563-570.

- 1997. A revision of the genus Mouretia (Rubiaceae). Nordic J. Bot. 123-132.

. 1998. Cyaneuron (Rubiaceae), a new genus from Borneo and Sulawesi. Nordic J. Bot. 147158.

Terrell, E. E., W. H. Lewis, H. Robinson \& J. W. Nowicke. 1986. Phylogenetic implications of diverse seed types, chromosome numbers and pollen morphology in Houstonia (Rubiaceae). Amer. J. Bot., 73: $103-115$.

Thiele, K. 1993. The holy grail of the perfect character: The cladistic treatment of morphometric data. Cladistics 9: 275-304.

Tilney, P. M. 1986. The taxonomic significance of anatomical and morphological characters in the southern African species of Canthium Lam. (Rubiaceae). Ph.D. diss., Univ. of Pretoria.

\& A. E. Van Wyk. 1997. Pollen morphology of Canthium, Keetia and Psydrax (Rubiaceae: Vanguerieae) in southern Africa. Grana 36: 249-260. 
Tirvengadum, D. D. 1982. Ramosmania, a new monotypic genus of Mascarene Rubiaceae. Nordic J. Bot. 2: $323-327$.

- 1984. Glionnetia, nouveau genre de Rubiacées (Rondeletiées) des Seychelles. Bull. Mus. Natl. Hist. Nat., B, Adansonia 6: 197-205.

- 1993. Larsenaikia, a new genus of the Rubiaceae from Australia. Nordic J. Bot. 13: 175-184.

- 1998. Novelties in Rubiaceae from the limestone flora of southeast Asia. Biogeographica (The Hague) 74: 163-175.

\& E. Robbrecht. 1985. Remarks on three Hypobathreae from Rodrigues, Seychelles and Sri Lanka. Nordic J. Bot. 5: 455-461.

Tissot, C. \& R.W. J. M. van der Ham. 1994. Seventh bibliographic index to the pollen morphology of Angiosperms. Trav. Sect. Sci. Techn. Inst. Franç. Pondichérie 27: 1-345.

, H. Chikhi \& T.S. Nayar. 1994. Pollen of wet evergreen forests of the western Ghats, India. Trav. Sect. Sci. Techn. Inst. Franç. Pondichérie 35: 1-133.

Van Campo, M. 1976. Patterns of pollen morphological variation within taxa. Pp. 125-137 in I. K. Ferguson \& J. Muller (eds.), The evolutionary significance of the exine. Linnean Soc. Symp. ser. 1. Acad. Press, London. . 1978. La face interne de l'exine. Rev. Palaeobot. Palynol. 26: 301-311.

Vanthournout, S. 2002. Geophila. Revisie van de paleotropische taxa. Licentiate thesis, Catholic Univ. of Leuven.

Verdcourt, B. 1958. Remarks on the classification of the Rubiaceae. Bull. Jard. Bot. État. 28: 209-290. - 1980. A conspectus of Polysphaeria (Rubiaceae). Kew Bull. 35: 97-130.

. 1981. Notes on African Rubiaceae. Kew. Bull. 36: 493-557.

1983. Notes on Mascarene Rubiaceae. Kew Bull. 37: 521-574.

—. 1987. Notes on African Rubiaceae-Vanguerieae. Kew Bull. 42: 123-199.

Verellen, J. 2002. Palynologische studie en revisie van Coptosapelta (Rubiaceae). Licentiate thesis, Catholic Univ. of Leuven.

E. Smets \& S. Huysmans. 2004. The remarkable genus Coptosapelta (Rubiaceae): Pollen and orbicule morphology and systematic implications. J. Pl. Res. 117: 57-68.

—, S. Huysmans, S. G. Razafimandimbison \& E. Smets. Submitted. Pollen morphology of the tribe Naucleeae s. lat. (Rubiaceae-Cinchonoideae) and its taxonomic and phylogenetic significance. Bot. J. Linn. Soc.

Vinckier, S., S. Huysmans \& E. Smets. 2000. Morphology and ultrastructure of orbicules in the subfamily Ixoroideae (Rubiaceae). Rev. Palaeobot. Palynol. 108: 151-174.

Weber, M. \& A. Igersheim. 1994. "Pollen buds" in Ophiorrhiza (Rubiaceae) and their role in pollenkitt release. Bot. Acta 107: 257-262.

Wodehouse, R. P. 1935. Pollen grains. McGraw-Hill, New York.

Ying, T.-S., Y.-L. Zhang \& D. E. Boufford. 1993. The endemic genera of seed plants of China. Science Press, Beijing.

Young, B. A., J. Schulz-Schaeffer \& T. W. Caroll. 1979. Anther and pollen development in malesterile intermediate wheatgrass plants derived from wheat $\mathrm{x}$ wheatgrass hybrids. Canad. J. of Bot. 57: 602-618. 


\section{Appendix 1: Template for Pollen Descriptions}

The pollen template below includes the essential characters for describing Rubiaceae pollen. Many other characters, such as the thickness of the different pollen wall layers or the size of the perforations and/or lumina, should be included whenever available. Also, special features, such as protruding onci, pollen buds, and margines, should be discussed when observed. If the species investigated are heterostylous, one should try to study pollen of all forms. Orbicules should also be described, at least naming the type, and, if there is certainty of negative reports (absence of orbicules), this should also be specified.

Pollen dispersed as (monads - tetrads - massulae)

Pollen grains (isopolar - heteropolar); (number of apertures) (zono - panto) aperturate; equatorial diameter (give size range); polar axis (give size range); equatorial shape (peroblate oblate - suboblate - spheroidal - subprolate - prolate - perprolate, or give $\mathrm{P} / \mathrm{E}$ range); polar outline or amb (triangular - quadrangular - circular - lobed - . . )

Apertures (simple or compound); ectoapertures (colpus - porus) - mesoapertures (absent/present - colpus - porus) - aspis (absent/present) - endoapertures (absent/present - porus - colpus

- endocingulum); costa (absent/present)

Tectum (perforate - microreticulate - reticulate $-\ldots$. ); supratectal elements (absent/present granules - microspines - spines)

Inner nexine surface (granular - smooth); endocracks (absent/present - description)

\section{Appendix 2: List of Genera in the Pollen Database, with Reference to the Literature}

This appendix lists the genera for which "good" pollen morphological data are available, arranged in alphabetical order. In parentheses, the most relevant pollen sources are cited, with the number of species investigated for each contribution, the number of species investigated compared with the total number of species. If the number of species investigated cannot be deduced from the manuscript, a question mark is used. The total number of species given represents the best estimate we can make at present (a reference for each figure can be found in the database). For comparison, the number of species for each genus according to Mabberley (1997) is given in parentheses; if the genus is not listed or not recognized by Mabberley, a dash is used. More literature references can be found in the database at <http://www.kuleuven.ac.be/ bio/sys/pollen.htm>. Genera for which we found only poor and/or unreliable pollen data are listed in the "Results" section of the text.

Acranthera Arn. ex Meisn. (Mathew \& Philip, 1983: 1/(35)35).

Acunaeanthus Borhidi, Jarai-Koml. \& Moncada (Borhidi et al., 1980: 1/(1)1)

Adenorandia Vermoesen (Malplanche, 1971: 1/(1)1, as Pseudogardenia; Keddam-Malplanche,

1985: 1/(1)1, as Pseudogardenia; Persson, 1993: 1/(1)1, as Pseudogardenia)

Adina Salisb. (Verellen et al., submitted: 2/(3)3)

Adinauclea Ridsdale (Verellen et al., submitted: 1/(1)1)

Agathisanthemum Klotzsch (Dessein, unpubl.: 3/(5-6)3-4)

Aidia Lour. (Puttock, 1992: 1/(18)60; Persson, 1993: 3/(18)60, 2 as Anomanthodia)

Aidiopsis Tirveng. (Persson, 1993: 1/(1)1)

Airosperma K. Schum. \& Lauterb. (Darwin, 1980a: 6/(6)6)

Aitchisonia Hemsl. ex Aitch. (Robbrecht, 1982b: 1/(1)1)

Alberta E. Mey. (Puff et al., 1984: 4/(6)6) 
Aleisanthia Ridl. (Tange, 1996a: 2/(2)2; Huysmans, 1998: 1/(2)2)

Aleisanthiopsis Tange (Tange, 1996b: 2/(-)2)

Alibertia A. Rich. (Persson, 1993: 13/(35)50)

Alleizettella Pit. (Robbrecht \& Puff, 1986: 1/(1)2)

Alseis Schott (Andersson, 1993: 6/(20)16; Huysmans, 1998: 3/(20)16)

Amaioua Aubl. (Persson, 1993: 2/(25)9)

Amphiasma Bremek. (Dessein, unpubl. 3/(5-6)7-8)

Amphidasya Standl. (Huysmans et al., 1998a: 1/(7)8)

Ancyclanthos Desf. (Igersheim, 1989: 1+1/(5)1, as Ancylanthus; Lens et al., 2000: 1/(5)1)

Anthospermum L. (Robbrecht, 1982b: 2/(40)39)

Aoranthe Somers (Huysmans et al., 1998a: 2/(2)5; Keddam-Malplanche, 1980: 2/(2)5, as

Porterandia spp.; Keddam-Malplanche, 1985: 4/(2)5, as Porterandia spp.)

Aphaenandra Miq. (Huysmans et al., 1998a: 1/(2)1)

Aphanocarpus Steyerm. (Piesschaert, 2001: 1/(1)1)

Appunia Hook. f. (Johansson, 1987a: 1/(-)ca. 15)

Arachnothryx Planch. (Borhidi, 1982: 1/(80)80)

Arcytophyllum Willd. (Huysmans, 1998: 1/(15)16)

Argocoffeopsis Lebrun (Robbrecht, 1981b: 6/(8)7; Chinnappa \& Warner, 1981: 5/(8)7, as Coffea

spp.)

Argostemma Wall. (Mathew \& Philip, 1983: 1/(100)196)

Ariadne Urb. (Huysmans, 1998: 1/(2)1)

Asemnantha Hook. f. (Huysmans et al., 1999: 1/(1)1)

Asperula L. (Huysmans et al., 2003: 5/(90)150)

Atractocarpus Schltr. \& K. Krause (Puttock, 1992: 3/(20)12, as Gardenia merikin, Randia

hirta, R. stipularis; Persson, 1993: 1/(20)12)

Atractogyne Pierre (Persson, 1993: 1/(3)3)

Augusta Pohl (Huysmans, 1998: 1/(1)1)

Badusa A. Gray (Huysmans et al., 1999: 1/(3)3)

Balmea Martínez (Andersson, 1993: 1/(1)1; D’hondt et al., 2004: 1/(1)1)

Bathysa C. Presl (Andersson, 1993: 1/(2)14, as Schizocalyx; Huysmans, 1998: 1/(2)14, as Schizocalyx)

Batopedina Verdc. (Robbrecht, 1981a: 1/(3)3; Dessein et al., 2000: 3/(3)3)

Belonophora Hook. f. (Robbrecht, 1980: 1/(6)8)

Benkara Adans. (Persson, 1993: 1/4)

Bertiera Abul. (Robbrecht et al., 1993: 8/(55)50)

Bikkia Reinw. (Huysmans et al., 1999: 3/(20)20)

Blepharidium Standl. (D'hondt et al., 2004: 2/(2)2)

Borojoa Cuatrec. (Persson, 1993: 4/(8)11)

Brachytome Hook. f. (Persson, 1993: 1/(4)8)

Brenania Keay (Keddam-Malplanche, 1985: 1/(1)2; Persson, 1993: 1/(1)2)

Breonadia Ridsdale (Verellen et al., submitted: 1/(1)1)

Breonia A. Rich. (Verellen et al., submitted: 4/(5)20; Mathew \& Philip, 1983: 1/(5)20, as Anthocephalus)

Burchellia R. Br. (Malplanche, 1971: 1/(1)1; Persson, 1993: 1/(1)1)

Burttdavya Hoyle (Verellen et al., submitted: 1/(1)1)

Byrsophyllum Hook. f. (Persson, 1993: 2/(2)2) 
Caelospermum Blume (Johansson, 1987a: 5/(7)7)

Calanda K. Schum. (Puff \& Robbrecht, 1989: 1/(1)1)

Calochone Keay (Keddam-Malplanche, 1985: 2/(2)2; Persson, 1993: 1/(2)2)

Calycophyllum DC. (Andersson, 1993: 1/(3)6; Huysmans, 1998: 2/(3)6)

Calycosiphonia Pierre ex. Robbr. (Robbrecht, 1981b: 1/(2)2)

Canthium Lam. (Tilney, 1986: 6/(50)162; Verdcourt, 1987: 2/(50)162; Igersheim, 1989: 9/ (50)162; Tilney \& Van Wyk, 1997: 9/(50)162; Lens et al., 2000: 6/(50)162; Mathew \& Philip, 1983: 3/(50)162, as Plectronia neilgherrensis, P. rheedii, P. rheedii var. angustifolia) Capirona Spruce (Andersson, 1993: 2/(5)2; Huysmans, 1998: 1/(5)2)

Captaincookia N. Hallé (De Block \& Robbrecht, 1998: 1/(1)1)

Carpacoce Sond. (Robbrecht, 1982b: 1/(7)7; Robbrecht, 1985: 7/(7)7)

Carphalea Juss. (Puff, 1988: 9/(10)10; Scheltens, 1998: 1/(10)10)

Casasia A. Rich. (Persson, 1993: 2/(11)10)

Catesbaea L. (Huysmans et al., 1999: 5/(20)ca. 16; Mathew \& Philip, 1983: 1/(20)ca. 16)

Catunaregam Wolf (Verdcourt, 1981: 1/(5-6)6; Persson, 1993: 1/(5-6)6 )

Cephalanthus L. (Huysmans, unpubl.: 5/(6)6-7)

Ceratopyxis Hook. f. (Huysmans et al., 1999: 1/(1)1)

Ceriscoides Hook. f. Tirveng. (Persson, 1993: 1/(7)6)

Chamaepentas Bremek. (Dessein et al., 2000: 1/(1)1)

Chassalia Comm. ex Juss. (Mathew \& Philip, 1983: 1/(42)ca. 82, as Chasalia; Piesschaert et al., 1999c: 1/(42)ca. 80; Jansen et al., 1996a: 3/(42)ca. 80; Jansen, 1994: 4/(42)ca. 80)

Chazaliella E. M. A. Petit \& Verdc. (Jansen, 1994: 3/(25)21; Jansen et al., 1996a: 3/(25)21)

Chimarrhis Jacq. (Huysmans, 1998: 1/(14)13; Delprete, 1999a: 10/(14)13)

Chiococca P. Br. (Huysmans et al., 1999: 2/(6)ca. 20)

Chione DC. (Huysmans, unpubl. 2/(15)15)

Chlorochorion Puff \& Robbr. (Puff \& Robbrecht, 1989; 1/(2)2)

Chomelia Jacq. (Jung-Mendaçolli \& Melhem, 1994: 1/(20)75)

Cinchona L. (Andersson, 1993: 7/(40)23; Mathew \& Philip, 1983: 3/(40)23)

Cladoceras Bremek. (Robbrecht \& Bridson, 1984: 1/(1)1; De Block \& Robbrecht, 1998: 1/ (1)1)

Coccocypselum P. Br. (Piesschaert et al., 2000b: 4/(20)37; Rova \& Andersson, 1995: 1/(20)37; Jung-Mendaçolli \& Melhem, 1995: 4/(20)37)

Coddia Verdc. (Verdcourt, 1981: 1/(1)1; Persson, 1993: 1/(1)1 )

Coffea L. (Chinnappa \& Warner, 1981, 1982: 17/(90)95-100; Stoffelen et al., 1997: 26/(90)95100)

Coleactina N. Hallé (De Block \& Robbrecht, 1998: 1/(1)1)

Colletoecema E. M. A. Petit (Piesschaert et al., 2000a: 1/(1)1)

Condaminea DC. (Huysmans, 1998: 1/(3)1; Delprete, 1999a: 1/(3)1)

Conostomium (Stapf) Cufod. (Dessein, unpubl.: 4/(9)9)

Coprosma J. R. Forst. \& G. Forst. (Robbrecht, 1982b: 2/(90)150; Mathew \& Philip, 1983: 1/ (90)150)

Coptosapelta Korth. (Verellen, 2002: 11/(13)16; Verellen et al., 2004: 10/(13)16)

Coptosperma Hook. f. (De Block \& Robbrecht, 1998: 11/(-)50 10 spp. as Enterospermum, 1 as Tarenna nigrescens; De Block et al., 2001 [2002]: ?/(-)50)

Corynanthe Welw. (Huysmans, 1993: 3/(8)3)

Coryphothamnus Steyerm. (Piesschaert, 2001: 1/(1)1)

Cosmibuena Ruiz \& Pav. (Andersson, 1993: 1/(12)4; D'hondt et al., 2004: 4/(12)4) 
Coussarea Aubl. (Piesschaert, 2001: 3/(ca. 100)118; see also Jung-Mendaçolli \& Melhem, 1995)

Coutaportla Urb. (Huysmans et al., 1999: 1/(2)3-4)

Coutarea Aubl. (Huysmans et al., 1999: 1/(7)3-4; Rova \& Andersson, 1995: 1/(7)3-4)

Crossopteryx Fenzl (Huysmans, unpubl.: 1/(1)1)

Crucianella L. (Huysmans et al., 2003: 3/(ca. 30)33)

Cruciata Mill. (Huysmans et al., 2003: 2/(10)11)

Cruckshanksia Hook. \& Arn. (Dessein, unpubl.: 2/(7)7)

Crusea Cham. \& Schltdl. (Anderson, 1972: 13/(13)14; Dessein, 2003: 2/(13)14)

Cubanola Aiello (Aiello, 1979: ?/(2)2)

Cuviera DC. (Verdcourt, 1987: 1/(20)23; Igersheim, 1989: 4/(20)23; Lens et al., 2000: 2/(20)23)

Cyaneuron Tange (Tange, 1998: 5/(-)5)

Damnacanthus C. F. Gaertn. (Johansson, 1987a: 2/(6)10; Robbrecht et al., 1991: 1/(6)10; Naiki \& Nagamasu, 2003: 4/(6)10)

Danais Comm. ex Vent. (Buchner \& Puff, 1993: 15/(40)ca. 29; Scheltens, 1998: 1/(40)ca. 29; see also Huysmans, 1998)

Deccania Tirveng. (Persson, 1993: 1/(1)1)

Declieuxia Kunth (Piesschaert et al., 2000b: 15/(27)?40; Jung-Mendaçolli \& Melhem, 1995: $1 /(27) ? 40)$

Dentella J. R. Forst. \& G. Forst. (Mathew \& Philip, 1983: 1/(10)8)

Dialypetalanthus Kuhlm. (Piesschaert et al., 1997: 1/(1)1)

Dibrachionostylus Bremek. (Dessein, unpubl.: 1/(1)1)

Dichilanthe Thw. (Puff et al., 1996: 1/(2)2)

Dictyandra Hook. f. (Robbrecht, 1984: 2/(2)2; De Block \& Robbrecht, 1998: 1/(2)2)

Didymosalpinx Keay (Keddam-Malplanche, 1985: 1/(4)4; Persson, 1993: 2/(4)4)

Diodella Small (Dessein, 2003: 1/(-)?)

Diodia L. (Pire, 1997a: 1/(30)5; Dessein, 2003: 2/(30)5)

Dioecrescis Tirveng. (Persson, 1993: 1/(1)1)

Dioicodendron J. A. Steyermark (Delprete, 1999a: 1/(2)1)

Diplospora DC. (Ali \& Robbrecht, 1991: 3/(10)19; Mathew \& Philip, 1983: 1/(10)19)

Discospermum Dalzell (Ali \& Robbrecht, 1991: 1/(6)6)

Dolichodelphys K. Schum. (Delprete, 1999a: 1/(1)1)

Dolicholobium A. Gray (Andersson, 1993: 1/(28)28; Huysmans, 1998: 1/(28)28)

Doricera Verdc. (Verdcourt, 1983: 1/(1)1)

Dunnia Tutcher (Ying et al., 1993: 1(2)2)

Duperrea Pierre ex Pit. (De Block, 1997: 1/(2)2)

Duroia L. f. (Persson, 1993: 5/(20)34)

Durringtonia R. J. F. Hend. \& Guymer (Puff \& Robbrecht, 1988: 1/(1)1)

Ecpoma K. Schum. (Huysmans et al., 1998a: 1/(1)5+1)

Elaeagia Wedd. (Huysmans, 1998: 2/(10)22)

Emmenopterys Oliv. (Ying et al., 1993: 1/(2)2)

Emmeorhiza Pohl. ex Endl. (Pire \& Cabral, 1992: 1/(1)1; Dessein, 2003: 1/(1)1)

Erithalis P. Br. (Huysmans et al., 1999: 2/(10)9)

Ernodea Sw. (Negrón-Ortiz, 1996: 4/(9)4; Dessein, 2003: 1/(9)4)

Euclinia Salisb. (Persson, 1993: 1/(3)3)

Exallage Bremek. (Mathew \& Philip, 1983: 1/(-)24)

Exostema (Pers.) Rich. ex Humb. \& Bonpl. (Huysmans et al., 1999: 2/(45)47) 
Fadogia Schweinf. (Verdcourt, 1987: 2/(45)44; Igersheim, 1989: 5+1/(45)44, 1 as Ancylanthus rogersii; Lens et al., 2000: 1/(45)44)

Fadogiella Robyns (Igersheim, 1989: 1/(2)3; Lens et al., 2000: 1/(2)3)

Fagerlindia Tirveng. (Persson, 1993: 3/(6)9)

Faramea Aubl. (Jung-Mendaçolli \& Melhem, 1995: 1/(125)130; Piesschaert, 2001: 2/(125)130)

Ferdinandusa Pohl (Andersson, 1993: 10/(24)20; Huysmans, 1998: 3/(24)20)

Gaertnera Lam. (Jansen, 1994: 4/(30)60; Jansen et al., 1996b: 7/(30)60; Pailler \& Thompson, 1997: 8/(30)60)

Gaillonia A. Rich. (Robbrecht, 1982b: 3/(17)27, 1 as Crocyllis anthospermoides, 2 as Neogaillonia spp.; Léonard, 1984: 1/(17)27)

Galianthe Griseb. (Pire \& Cabral, 1992: 20/(-)50; Pire, 1997a: 8/(-)50; Dessein, 2003 (2/(-)50)

Galium L. (Huysmans et al., 2003: 16/(ca. 300)400; Mathew \& Philip, 1983: 1/(ca. 300)400)

Galopina Thunb. (Robbrecht, 1982b: 1/(-)1)

Ganguelia Robbr. (Robbrecht et al., 1996: 1/(-)1)

Gardenia Ellis (Persson, 1993: 2/(60)154; Mathew \& Philip, 1983: 2/(60)154; Puttock, 1992: $18 /(60) 154)$

Genipa L. (Persson, 1993: 2/(7)4)

Gentingia J. T. Johanss. \& K. M. Wong (Johansson \& Wong, 1988: 1/(1)1)

Geophila D. Don (Piesschaert et al., 1999b: 6/(ca. 20)19; Es, 1999: 5/(ca. 20)19; Vanthournout, 2002: 10/(ca. 20)19; Mathew \& Philip, 1983: 1/(ca. 20)19)

Gleasonia Standl. (Rogers, 1984: 2/(5)4)

Glionnetia Tirveng. (Tirvengadum, 1984: 1/(1)1)

Glossostipula Lorence (Lorence, 1986: 1/(2)3; Persson, 1993: 1/(2)3)

Gomphocalyx Baker (Dessein et al., 2005a: 1/(1)1)

Gonzalagunia Ruiz \& Pav. (Huysmans et al., 1998a: 3/(15)43)

Gouldia A. Gray (Huysmans et al., 1998a: 1(3x)/(-)3, three different species given, but two placed in synonymy

Greeniopsis Merr. (Huysmans, unpubl.: 4/(6)6)

Guettarda L. (Sotolongo Molina et al., 2002: 19/(80)ca. 85; Mathew \& Philip, 1983: 1/(80)ca. 85)

Gynochthodes Blume (Johansson, 1987a: 3+2/(ca. 20)14)

Gyrostipula J.-F. Leroy (Verellen et al., submitted: 1/(2)1-2)

Habroneuron Standl. (Darwin, 1980b: 1/(1)1)

Haldina Ridsdale (Verellen et al., submitted: 1/(1)1)

Hallea J.-F. Leroy (Huysmans et al., 1994: 3/(3)3)

Hamelia Jacq. (Huysmans, unpubl.: 6/(16)17; Mathew \& Philip, 1983: 1/(16)17)

Hedyotis L. (Mathew \& Philip, 1983: 1+2(250)65, as Oldenlandia pruinosa, O. ramarowii)

Hedythyrsus Bremek. (Dessein, unpubl.: 2/(2)2)

Heinsia DC. (Huysmans et al., 1998a: 3/(4-5)6)

Hekistocarpa Hook. f. (Dessein et al., 2001b: 1/(1)1)

Henriquezia Spruce ex Benth. (Rogers, 1984: 3/(7)3)

Hillia Jacq. (Andersson, 1993: 1/(24)24; D'hondt et al., 2004: 19/(24)24); see also D'hondt, 2002)

Himalrandia T. Yamazaki (Lobreau-Callen, 1978: 1/(2)3; Verdcourt, 1981: 1/(2)3)

Hindsia Benth. ex Lindl. (Piesschaert et al., 2000b: 2/(8)11; Huysmans, 1998: 1/(8)11)

Hintonia Bullock (Huysmans et al., 1999: 3/(4)3)

Hippotis Ruiz. \& Pav. (Rova \& Andersson, 1995: 2/(12)11) 
Hoffmannia Sw. (Huysmans, unpubl.: 5/(ca. 45)119)

Homollea Arènes (De Block \& Robbrecht, 1998: 1/(3)3)

Homolliella Arènes (De Block \& Robbrecht, 1998: 3/(1)5)

Houstonia L. (Dessein, unpubl.: 15/(-)20; Terrell et al., 1986: ?/(-)20, as Hedyotis)

Hutchinsonia Robyns (Igersheim, 1989: 1/(2)2)

Hydrophylax L. f. (Puff, 1986b: 1/(1)1; Dessein, 2003: 1/(1)1

Hymenocoleus Robbr. (Robbrecht, 1977: 11/(12)12)

Hymenodictyon Wall. (Huysmans, 1993: 5/(20)26; Mathew \& Philip, 1983: 1/(20)26)

Hyperacanthus E. Mey. ex Bridson (Bridson \& Robbrecht, 1985a: 1/(2)2; Persson, 1993: 1/(2)2)

Isertia Schreb. (Bosser \& Lobreau-Callen, 1998: 1/(13)14; Huysmans et al., 1998a: 5/(13)14)

Isidorea A. Rich. (Huysmans et al., 1999: 3/(20)17)

Ixora L. (De Block \& Robbrecht, 1998: 29/(300)400, 5 unidentified; see also De Block, 1998;

Mathew \& Philip, 1983: 4+1/(300)400, 1 as Pavetta calycina)

Jackiopsis Ridsdale (Robbrecht, 1980: 1/(1)1)

Janotia J.-F. Leroy (Verellen et al., submitted: 1/(1)1)

Jaubertia Guill. (Robbrecht, 1982b: 1/(16)1, as Neogaillonia aucheri)

Javorkaea Borhidi et J. Komlódi (Borhidi \& Járai-Komlódi, 1983: 1/(1)1)

Joosia H. Karst. (Andersson, 1993: 6/(7)11; Huysmans, 1998: 1/(7)11)

Jovetia Guédès (Robbrecht, 1980: 1/(2)1)

Kailarsenia Tirveng. (Persson, 1993: 1/(6)6; Tirvengadum, 1993: 1/(6)6)

Kajewskiella Merrill et Perry (Delprete, 1999a: 1/(2)2)

Keetia E. Phillips (Tilney, 1986: 1/(40)31, as Canthium gueinzii; Verdcourt, 1987: 1/(40)31;

Igersheim, 1989: 14/(40)31; Tilney \& Van Wyk, 1997: 1/(40)31: Lens et al., 2000: 3/(40)31)

Kelloggia Torr. ex Benth. (Robbrecht, 1982b: 1/(2)2)

Kerianthera J. H. Kirkbr. (Delprete, 1999a: 1/(1)1)

Knoxia L. (Mathew \& Philip, 1983: 2/(9)9)

Kochummenia K. M. Wong (Persson, 1993: 1/(2)2)

Kohautia Cham. \& Schltdl. (Dessein, unpubl., 20/(-)31)

Kutchubaea Fisch. ex DC. (Robbrecht, 1980: 1/(11)11; Persson, 1993: 2/(11)11)

Ladenbergia Klotzsch (Andersson, 1993: 6/(55)34; Huysmans, 1998: 1/(55)34)

Lagynias E. Mey ex Robyns (Igersheim, 1989: 1/(4)5; Lens et al., 2000: 1/(4)5)

Lamprothamnus Hiern (Robbrecht, 1980: 1/(1)1)

Landiopsis Capuron ex Bosser (Bosser \& Lobreau-Callen, 1998: 1/(-)1)

Larsenaikia Tirveng. (Puttock, 1992: 3(-)3, as Gardenia ochreata, G. suffruticosa, G. jardinei; Tirvengadum, 1993: 1/(-)3)

Lasianthus W. Jack. (Adams et al., 1987: 1/(170)>180; Huang, 1972: 8/(170)>180; Piesschaert et al., 2000a: ?/(170)>180)

Lathraeocarpa Bremek. (Dessein et al., 2005a: 1/(2)2)

Lecananthus Jack (Puff \& Buchner, 1998: 2/(-)3)

Lelya Bremek. (Dessein, unpubl.: 1/(1)1)

Leptactina Hook. f. (Robbrecht, 1984: ?5/(25)<20; De Block \& Robbrecht, 1998: 6/(25)<20) Leptodermis Wall. (Robbrecht, 1982b: 1/(30)41)

Leptostigma Arn. (Robbrecht, 1982b: 2/(6)6; 1 as Coynula pilosa, 1 as Nertera arnottianum $[$ sic $])$ 
Leucocodon Gardner (Puff \& Buchner, 1998: 1/(-)1)

Limnosipanea Hook. f. (Huysmans, 1998: 1/(7)5)

Lindenia Benth. (Darwin, 1976: 3/(3)3)

Ludekia Ridsdale (Verellen et al., submitted: 2/(2)2)

Luculia Sweet (Huysmans, 1993: 2/(5)5; Mathew \& Philip, 1983: 2/(5)5)

Macrocnemum P. Br. (Andersson, 1993: 3/(20)8; Huysmans, 1998: 1/(20)8)

Macrosphyra Hook. f. (Persson, 1993: 1/(3)3; Robbrecht, 1980: 2/(3)3)

Manettia Mutis ex L. (Huysmans, 1998: 1/(80)ca. 130; Rova \& Andersson, 1995: 1/(80)ca. 130; Jung-Mendaçolli \& Melhem, 1994: 2/(80)ca. 130; Jung-Mendaçolli \& Melhem, 1995 : $1 /(80)$ ca. 130)

Manostachya Bremek. (Dessein, unpubl.: 2/(3)3)

Mantalania Capuron ex J.-F. Leroy (Persson, 1993: 1/(2-3)2; Leroy, 1974: 2/(2-3)2)

Maschalocorymbus Bremek. (Huysmans, 1998: 1+1/(-)4)

Massularia (K. Schum.) Hoyle (Keddam-Malplanche, 1985: 1/(1)1; Persson, 1993: 1/(1)1)

Mastixiodendron Melch. (Huysmans et al., 1999: 2/(7)7; Darwin, 1977: 7/(7)7)

Melanopsidium Colla (Persson, 1993: 1/(?)1)

Metabolos Blume (Puff \& Igersheim, 1994a: 1/(-)1)

Metadina Bakh. f. (Verellen et al., submitted: 1/(1)1)

Meyna Roxb. ex Link (Igersheim, 1989: 1/(11)10; Lens et al., 2000: 1/(11)10)

Mitchella L. (Robbrecht, 1982b: 1/(3)2); Robbrecht et al., 1991: 1/(3)2)

Mitracarpus Zucc. ex Schult. \& Schult. f. (Dessein, 2003: 2/(30)45)

Mitragyna Korth. (Huysmans et al., 1994: 7/(10)7; Mathew \& Philip, 1983: 1/(10)7, as Stephegyne)

Mitrasacmopsis Jovet (Groeninckx, 2005: 1/(1)1)

Mitriostigma Hochst. (Persson, 1993: 1/(5)4; Hansson \& El-Ghazaly, 2000: 1/(5)4)

Molopanthera Turcz. (Huysmans et al., 1999: 1/(1)1)

Monosalpinx N. Hallé (Persson, 1993: 1/(1)1)

Morelia A. Rich. (Persson, 1993: 1/(1)1; Malplanche, 1971: 1/(1)1; Robbrecht, 1980: 1/(1)1)

Morierina Vieill. (Huysmans et al., 1999: 1/(2)2)

Morinda L. (Mathew \& Philips, 1983: 3/(80)115; Johansson, 1987a: 8/(80)115)

Motley(i)a J. T. Johanss. (Johansson, 1987a: 1/(1)1)

Mouretia Pit. (Tange, 1997: 4/(1)4)

Multidentia Gilli (Verdcourt, 1987: 1/(11)11; Igersheim, 1989: 1/(11)11)

Mussaenda L. (Huysmans et al., 1998a: 4/(100)216; Bosser \& Lobreau-Callen, 1998: 2/ (100)216; Rova \& Andersson, 1995: 1/(100)216; Mathew \& Philip, 1983: 3/(100)216)

Mussaendopsis Baill. (Huysmans, 1993: 2/(2)2; Puff \& Igersheim, 1994b: ?2/(2)2)

Mycetia Reinw. (Huysmans et al., 1998a: 3/(25)44)

Myonima Comm. ex Juss. (De Block \& Robbrecht, 1998: 2/(4)4)

Myrioneuron R. Br. ex Hook. f. (Huysmans et al., 1998a: 1/(-)14)

Myrmecodia Jack. (Robbrecht, 1988a: 1/(26)26; see also Huxley \& Jebb, 1993)

Myrmeconauclea Merr. (Verellen et al., submitted 3/(3)3)

Nauclea L. (Verellen et al., submitted: 9/(10)10; Mathew \& Philip, 1983: 2/(10)10)

Neanotis W. H. Lewis (Lewis, 1966: ?/(28)33; Mathew \& Philip, 1983: 2/(28)33)

Nematostylis Hook. f. (Puff et al., 1984: 1/(1)1)

Nenax Gaertn. (Robbrecht, 1982b: 1/(9)9+2)

Neohymenopogon Bennet (Huysmans, 1998: 1/(3)3) 
Neolamarckia Bosser (Verellen et al., submitted: 1/(2)2)

Neomussaenda Tange (Tange, 1994: 2/(-)2)

Neonauclea Merr. (Verellen et al., submitted: 9/(65)66)

Neopentanisia Verdc. (Puff \& Robbrecht, 1989: 1/(2)2)

Nernstia Urb. (Aiello, 1979: 1/(1)1, as Cigarilla; Huysmans et al., 1999: 1/(1)1)

Nertera Banks \& Sol. ex Gaertn. (Robbrecht, 1982b: 1+?/(9)15)

Neurocalyx Hook. (Mathew \& Philip, 1983: 1/(5)4)

Nichallea Bridson (De Block \& Robbrecht, 1998: 1/(1)1)

Normandia Hook. f. (Robbrecht, 1982b: 1/(1)1)

Ochreinauclea Ridsdale \& Bakh. f. (Verellen et al., submitted: 1/(2)2)

Octotropis Bedd. (Tissot et al., 1994: (1/(2)1)

Oldenlandia L. (Dessein, unpubl.: 7/(300)ca. 100; Mathew \& Philip, 1983: 7/(300)ca. 100)

Oligocodon Keay (Persson, 1993: 1/(1)1)

Opercularia Gaertn. (Robbrecht, 1982b: 2/(18)16)

Ophiorrhiza L. (Piesschaert et al., 2000a: ?/(150)313; Huang, 1972: 4/(150)313; Mathew \& Philip, 1983: 4/(150)313)

Osa Aiello (Aiello, 1979: 1/(1)1)

Otiophora Zucc. (Robbrecht \& Puff, 1981: 3/(20)18); Scheltens, 1998: 3/(20)18)

Otomeria Benth. (Dessein et al., 2000: 5/(8)8)

Oxyanthus DC. (Persson, 1993: 1/(40)40)

Oxyceros Lour. (Persson, 1993: 3/(?)14)

Pachystigma Hochst. (Igersheim, 1989: 3/(10)17; Lens et al., 2000: 1/(10)17)

Pachystylus K. Schum. (De Block \& Robbrecht, 1998: 1/(2)2)

Paederia L. (Robbrecht, 1982b: 1/(30)29; Igersheim, 1991: 28/(30)29)

Pagamea Aubl. (Jansen et al., 1996b: 3/(24)28)

Pagameopsis Steyerm. (Piesschaert et al., 2001: 2/(2)2)

Palicourea Aubl. (Jung-Mendaçolli, 1984: 4/(200+)ca. 200; Piesschaert, unpubl.: 9/(200+)ca. 200)

Paracephaelis Baill. (De Block \& Robbrecht, 1998: 4/(1)ca. 10; Bridson \& Robbrecht, 1985b: 1/(1)ca. 10, as Tarenna trichantha)

Parachimarrhis Ducke (Delprete, 1999a: 1/(1)1)

Paracorynanthe Capuron (Huysmans, 1993: 2/(2)2)

Paragenipa Baill. (Tirvengadum \& Robbrecht, 1985: 1/(1)1)

Parapentas Bremek. (Dessein et al., 2000: 3/(3-4)3+1)

Pauridiantha Hook. f. (Bangoura, 1992:11/(25)39; Ntore et al., 2003: 2/(25)39; Ntore, 2004: ?/(25)39)

Pausinystalia Pierre ex Beille (Huysmans, 1993: 4/(13)5; Verellen et al., submitted: 3/(13)5)

Pavetta L. (De Block \& Robbrecht, 1998: 14/(400)400; Mathew \& Philip, 1983: 1/(400)400)

Payera Baill. (Buchner \& Puff, 1993: 6/(1)9)

Pelagodendron Seem. (Persson, 1993: 1/(4)1)

Pentagonia Benth. (Rova \& Andersson, 1995: 2/(20)25-30)

Pentanisia Harv. (Puff \& Robbrecht, 1989: 1/(15)14)

Pentas Benth. (Dessein et al., 2000: 24/(34)39; Mathew \& Philip, 1983: 2/(34)39)

Pentodon Hochst. (Dessein, unpubl.: 1/(2)2)

Peponidium (Igersheim, 1989: 1/(20)20)

Perakanthus Robyns (Verdcourt, 1987: 1/(1)2) 
Perama Aubl. (Erdtman, 1971: 1/(9)13; !LM only)

Pertusadina Ridsdale (Verellen et al., submitted: 1/(4)4)

Petitiocodon Robbr. (Robbrecht, 1988b: 1/(1)1)

Phellocalyx Bridson (Bridson et al., 1980: 1/(1)1; Persson, 1993: 1/(1)1)

Phyllis L. (Robbrecht, 1982b: 1/(2)2)

Phylohydrax Puff (Puff, 1986b: 2/(2)2; Dessein, 2003: 2/(2)2)

Picardaea Urb. (Delprete, 1999a: 1/(2)1)

Pinckneya Rich. (Aiello, 1979: 1/(1)1; Delprete, 1999a: 1/(1)1)

Placocarpa Hook. f. (Huysmans et al., 1999: 1/(1)1)

Platycarpum Bonpl. (Rogers, 1984: 7/(10)12)

Pleiocoryne Rauschert (Persson, 1993: 1/(1)1)

Plocama Aiton (Robbrecht, 1982b: 1/(1)1; Lecuona Neumann et al., 1987: 1/(1)1)

Poecilocalyx Bremek. (Bangoura, 1992: 1/(2)4)

Pogonolobus F. Muell. (Johansson, 1987a: 1/(1)1)

Pogonopus Klotzsch (Delprete, 1999a: 3/(2-3)3)

Polysphaeria Hook. f. (Verdcourt, 1980: 5/(20)21)

Pomax Sol. ex DC. (Robbrecht, 1982b: 1/(-)1)

Porterandia Ridl. (Persson, 1993: 3/(9-10)10)

Portlandia P. Br. (Huysmans et al., 1999: 1/(6)5; Mathew \& Philip, 1983: 1/(6)5)

Posoqueria Aubl. (Persson, 1993: 2/(12)16)

Praravinia Korth. (Huysmans, 1998: 2+1/(50)49)

Preussiodora Keay (Robbrecht, 1978b: 1/(1)1; Persson, 1993: 1/(1)1)

Prismatomeris Thwaites (Johansson, 1987a: ?/(15)17; Johansson, 1987b: 13/(15)17)

Pseudomantalania J.-F. Leroy (Persson, 1993: 1/(1-2)1; Leroy, 1974 1/(1-2)1)

Pseudomussaenda Wernham (Huysmans et al., 1998a: 2/(4-5)6; see also Puff et al., 1993b)

Pseudopyxis Miq. (Robbrecht, 1982b: 1/(2)2; Puff, 1989: 2/(2)2)

Pseudosabicea N. Hallé (Huysmans et al., 1998a: 2/(12)13)

Psilanthus Hook. f. (Stoffelen et al., 1997: 6/(ca. 20)20; Chinnappa \& Warner, 1981 \& 1982: 3/ (ca. 20)20, as Coffea spp.)

Psychotria L. (Mathew \& Philip, 1983: 6/(800-1500)>1200; Johansson, 1992: 168/(8001500)>1200; Jansen, 1994: 8/(800-1500)>1200; Jansen et al., 1996b: 6/(800-1500)>1200; Piesschaert, unpubl.: 7/(800-1500)>1200)

Psydrax Gaertn. (Mathew \& Philip, 1983: 3/(100)51, as Plectronia didyma, P. pergracilis, P. umbellatum; Tilney, 1986: 2/(100)51, as Canthium locuples, C. obovatum; Igersheim, 1989: 15/(100)51; Tilney \& Van Wyk, 1997: 4/(100)51; Lens et al., 2000: 2/(100)51)

Psyllocarpus Mart. \& Zucc. (Kirkbride, 1979: 8/(8)8; Dessein, 2003: 2/(8)8)

Putoria Pers. (Robbrecht, 1982b: 1/(-)3)

Pygmaeothamnus Robyns (Robbrecht, 1980: 1/(4)2; Lens et al., 2000: 1/(4)2)

Pyrostria Comm. ex Juss. (Verdcourt, 1987: 2+1/(45)37, 1 as Dinocanthium; Igersheim, 1989: 2/(45)37; Lens et al., 2000: 1+1/(45)37)

Ramosmania Tirveng. (Tirvengadum, 1982: 1/(2)2)

Randia L. (Persson, 1993: 5/(100)ca. 90; Mathew \& Philip, 1983: 4/(100)ca. 90)

Raritebe Wernh. (Huysmans et al., 1998a: 1/(1)2)

Remijia DC. (Andersson, 1993: 8/(25)45)

Rennellia Korth. (Johansson, 1987a: 1+4/(4)4, 4 unidentified species)

Retiniphyllum Bonpl. (Cortés-B. \& Huysmans, submitted: 23/(20)23)

Rhipidantha Bremek. (Bangoura, 1992: 1/(1)1; Huysmans, unpubl.: 1/(1)1) 
Richardia L. (Pire, 1997b: 7/(15)15; Dessein, 2003: 2/(15)15; Mathew \& Philip, 1983: 1/ (15)15)

Riodocea Delprete (Delprete, 1999b: 1/(-)1)

Robbrechtia De Block (De Block, 2003: 2/(-)2)

Rogiera Planch. (Borhidi, 1982: 1/(18)?)

Roigella Borhidi \& M. Fernández Zeq. (Borhidi \& Fernández Zequeira, 1981a: 1/(1)1)

Rondeletia L. (Igersheim, 1993b: 20/(130)286; Bosser \& Lobreau-Callen, 1998: 1/(130)286;

El-Ghazaly et al., 2001: 1/(130)286; Mathew \& Philip, 1983: 1/(130)286)

Rosenbergiodendron Fagerlind (Gustafsson, 1998: 4/(-)4)

Rothmannia Thunb. (Keddam-Malplanche, 1985: 12/(40)ca. 40; Persson, 1993: 5/(40)ca. 40; Robbrecht, 1980: 1/(40)ca. 40)

Rubia L. (Huysmans et al., 2003: 2/(60)72; Mathew \& Philip, 1983: 1/(ca. 60)72)

Rubovietnamia Tirveng. (Tirvengadum, 1998: 1/(-)1)

Rudgea Salisb. (Jung-Mendaçolli, 1984: 3/(150)>120; Piesschaert, unpubl.: 6/(150)>120)

Rustia Klotzsch (Aiello, 1979: ?/(15)14; Huysmans, 1998: 1/(15)14; Delprete, 1999a: 12/(15)14)

Rutidea DC. (De Block \& Robbrecht, 1998: 15/(22)22)

Rytigynia Blume (Igersheim, 1989: 5/(60-70)83; Lens et al., 2000: 3/(60-70)83; Verdcourt, 1980: 6/(60-70)83)

Sabicea Aubl. (Huysmans et al., 1998a: 4/(120)ca. 130)

Sacosperma G. Taylor (Dessein, unpubl.: 1/(2)2)

Saldinia A. Rich. ex DC. (Piesschaert et al., 2000a: ?/(2)22)

Salzmannia DC. (Huysmans et al., 1999: 1/(1)1)

Saprosma Blume (Mathew \& Philip, 1983: 1/(1)1)

Sarcocephalus Afzel. ex Sabine (Verellen et al., submitted: 2/(2)2; Mathew \& Philip, 1983: 1/(2)2)

Scandentia E. L. Cabral \& Bacigalupo (Cabral \& Bacigalupo, 2001: 4/(-)4; Dessein, 2003: 1/(-)4)

Schismatoclada Baker (Buchner \& Puff, 1993: 3/(20)18)

Schizenterospermum Homolle ex Arènes (De Block \& Robbrecht, 1998: 2/(4)4)

Schizomussaenda Li (Huysmans et al., 1998a: 1/(-)1; see also Puff et al., 1993b)

Schizostigma Arn. ex Meisn. (Huysmans et al., 1998a: 1/(1)1)

Schmidtottia Urb. (Aiello, 1979: ?/(15)14)

Schradera Vahl (Puff et al., 1993a \& Puff \& Buchner, 1998: ?/(25)64)

Schumanniophyton Hams. (Keddam-Malplanche, 1985: 1/(5)6; Persson, 1993: 1/(5)6)

Schwendenera K. Schum. (Dessein, 2003: 1/(1)1)

Scleromitrion (Wight \& Arn.) Meisn. (Mathew \& Philip, 1983: 1/(-)12, as Oldenlandia nitida)

Scolosanthus Vahl (Huysmans et al., 1999: 1/(27)27)

Scyphiphora C. f. Gaertn. (Puff \& Rohrhofer, 1993: 1/(1)1)

Scyphochlamys Balf. f. (Verdcourt, 1983: 1/(1)1)

Semaphyllanthe L. Andersson (Andersson, 1993: 3/(/)6, as Calycophyllum spp.)

Sericanthe Robbr. (Robbrecht, 1978a: 1/(15)17)

Serissa Comm. (Robbrecht, 1982b: 1/(2)2; Mathew \& Philip, 1983: 1/(2)2)

Sherardia L. (Huysmans et al., 2003: 1/(1)1)

Sherbournia G. Don (Persson, 1993: 1/(10)13; Keddam-Malplanche, 1980: 7/(10)13)

Simira Aubl. (Huysmans, 1998: 1/(35)41)

Sinoadina Ridsdale (Verellen et al., submitted: 1/(1)1)

Sipanea Aubl. (Huysmans, 1998: 2/(17)19; Dessein, unpubl.: 2/(17)19)

Sipaneopsis Steyerm. (Huysmans, 1998: 1/(6)8)

Sommera Schltdl. (Rova \& Andersson, 1995: 2/(12)13) 
Spermacoce L. (Dessein et al., 2002a: 48/(150)275; Dessein et al., 2002b: 1/(150)275; Dessein et al., 2005b: 47/(150)275; Pire, 1996: 50/(150)275, most as Borreria; Mathew \& Philip, 1983: 4/(150)275, 3 as Borreria spp., 1 as Mitracarpus verticillatus)

Spermadictyon Roxb. (Robbrecht, 1982b: 1/(1)1)

Sphinctanthus Benth. (Persson, 1993: 2/(3)7)

Squamellaria Becc (Robbrecht, 1988a: 1/(3)3)

Stachyarrhena Hook. f. (Persson, 1993: 4/(10)11)

Staelia Cham. \& Schltdl. (Dessein, 2003: 4/(12)15)

Stelechantha Bremek. (Bangoura, 1992: 2/(1)4; Huysmans, unpubl.: 1/(1)4)

Stephanococcus Bremek. (Dessein, unpubl.: 1/(1)1)

Stevensia Poit. (Huysmans, 1998: 1/(8)11)

Stilpnophyllum Hook. f. (Andersson, 1993: 2/(1)4)

Stipularia P. Beauv. (Huysmans et al., 1998a: 2/(-)2)

Strumpfia Jacq. (Igersheim, 1993a: 1/(1)1; Bridson \& Robbrecht, 1985b: 1/(1)1)

Suberanthus Borhidi \& M. Fernández Zeq. (Borhidi \& Fernández-Zequeira, 1981b: ?/(7)5; Borhidi \& Fernández-Zequeira, 1983: ?/(7)5)

Sukunia A. C. Sm. (Persson, 1993: 1/(2)2)

Sulitia Merr. (Persson, 1993: 1/(-)1)

Syringantha Standl. (McDowell, 1996: 1/(1)1)

Tamilnadia Tirveng. (Persson, 1993: 1/(-)1)

Tammsia H. Karst. (Rova \& Andersson, 1995: 1/(1)1)

Tapiphyllum Robyns (Havard \& Verdcourt, 1987: 7/(20)18; Igersheim, 1989: 2/(20)18; Lens et al., 2000: 1/(20)18)

Tarenna Gaertn. (De Block \& Robbrecht, 1998: 26/(180)219; De Block et al., 2001 [2002]: ?/ (180)219)

Tarennoidea Tirveng. (Persson, 1993: 1/(?)2)

Temnopteryx Hook. f. (Huysmans et al., 1998a: 1/(1)1)

Tennantia Verdc. (Verdcourt, 1981: 1/(-)1; De Block \& Robbrecht, 1998: 1/(1)1)

Theligonum L. (Rutishauser et al., 1998: 1/(3)3; Behnke, 1975: 1/(3)3)

Timonius DC. (Darwin, 1993: 6/(150)180; Darwin, 1994: 18/(150)180)

Tobagoa Urb. (Dessein, 2003: 1/(1)1)

Tocoyena Aubl. (Persson, 1993: 3/(20)28)

Trailliaedoxa W. W. Smith \& Forrest (Ying et al., 1993: 1/(1)1)

Tresanthera H. Karst. (Aiello, 1979: 1/(2)1; Delprete, 1999a: 1/(2)1)

Triainolepis Hook. f. (Dessein, unpubl.: 1/(8)11)

Tricalysia A. Rich. (Robbrecht, 1979, 1982a, 1983, 1987 give short comments on pollen)

Trichostachys Hook. f. (Piesschaert et al., 2000a: ?/(10)15)

Trukia Kaneh. (Puttock, 1992: 1/(5)5, as Randia fitzalanii; Persson, 1993: 1/(5)5)

Uncaria Schreb. (Huysmans, unpubl.: 3/(34)42; Verellen et al., submitted: 4/(34)42; Mathew \& Philip, 1983: 1/(34)42)

Valantia L. (Huysmans, unpubl.: 1/(3-4)7)

Vangueria Juss. (Verdcourt, 1987: 2/(15)19; Igersheim, 1989: 4/(15)19; Lens et al., 2000: 2/ (15)19)

Vangueriella Verdc. (Tilney, 1986: 1/(21)18, as Canthium spinosum; Verdcourt, 1987: 4/(21)18; Igersheim, 1989: 2/(21)18) 
Vangueriopsis Robyns (Verdcourt, 1987: 3/(4)4; Igerhseim, 1989: 2/(4)4; Lens et al., 2000: 1/ (4)4)

Versteegia Val. (De Block \& Robbrecht, 1998: 2/(2)4; Bridson \& Robbrecht, 1985b: 2/(2)4)

Vidalasia Tirveng. (Tirvengadum, 1998: 1/(-)5)

Virectaria Bremek. (Huysmans et al., 1998a: 2/(7)8; Dessein et al., 2001a: 6/(7)8)

Wendlandia Bartl. ex DC. (Huysmans, 1998: 2/(70)80; Mathew \& Philip, 1983: 1/(70)80)

Wittmackanthus Kuntze (Andersson, 1993: 1/(1)1)

Xanthophytum Reinw. ex Blume (Tange, 1995: ?/(30)33).

\section{Appendix 3: List of Genera according to Tribes}

This appendix gives the list of genera considered in this study, by tribe. The tribes are ordered by subfamily and therein as they appear on the summary cladogram starting with the basal taxa (Fig. 58). The delimitation of some tribes/groups as used here is still controversial and often based on relatively poor molecular evidence. These tribes are marked with an asterisk. Genera with an uncertain position are added at the end; these are not included in Table I, but their data will be found on the forthcoming pollen Internet site of the Laboratory of Plant Systematics, <http://www.kuleuven.ac.be/bio/sys/pollen.htm>.

\section{UNRESOLVED OR BASAL POSITION}

Coptosapelta; Luculia

\section{SUBFAMILY RUBIOIDEAE}

Ophiorrhizeae - Colletoecema: Colletoecema; Neurocalyx; Ophiorrhiza; Xanthophytum Pauridiantheae: Pauridiantha; Poecilocalyx; Rhipidantha; Stelechantha

Urophylleae: Amphidasya; Maschalocorymbus; Praravinia

Lasiantheae:* Lasianthus; Metabolos; Perama; Saldinia; Trichostachys

Cruckshanksieae: Cruckshanksia

Coussareeae:* Coussarea; Faramea

Coccocypseleae:* Coccocypselum; Declieuxia; Hindsia

Craterispermeae: /

Psychotrieae: Chassalia; Chazaliella; Geophila; Hymenocoleus; Myrmecodia; Palicourea; Rudgea; Psychotria; Squamellaria.

Note: The delimitation of several genera of the Psychotrieae is still in state of flux. Because it is remarkably variable in the tribe, pollen should be investigated to help determine generic boundaries.

Morindeae: Appunia; Caelospermum; Damnacanthus; Gentingia; Gynochthodes; Morinda; Motley(i)a; Pogonolobus; Prismatomeris; Rennellia

Schradereae: Schradera; Lecananthus; Leucocodon

Gaertnereae: Gaertnera; Pagamea

Danaideae: Danais; Payera; Schismatoclada

Hedyotideae - Pentas group:* Batopedina; Carphalea; Chamaepentas; Otiophora; Otomeria; Parapentas; Pentas 
Knoxieae:* Calanda; Chlorochorion; Knoxia; Neopentanisia; Pentanisia

Triainolepideae:* Triainolepis

Hedyotideae-Hedyotis group:* Agathisanthemum; Amphiasma; Arcytophyllum; Conostomium; Dentella; Dibrachionostylus; Exallage; Gomphocalyx; Gouldia; Hedyotis; Hedythyrsus; Houstonia; Kohautia; Lelya; Manettia; Manostachya; Mitrasacmopsis; Neohymenopogon; Neanotis; Oldenlandia; Pentodon; Phylohydrax; Scleromitrion

Spermacoceae s.str.: Crusea; Diodella; Diodia; Emmeorhiza; Ernodea; Galianthe; Hydrophylax; Mitracarpus; Psyllocarpus; Richardia; Scandentia; Schwendenera; Spermacoce; Staelia; Tobagoa

Note: The Hedyotideae - Hedyotis group and the Spermacoceae s.str. form a monophyletic group, which is here called "Spermacoceae s.l."

Anthospermeae: Anthospermum; Carpacoce; Coprosma; Durringtonia; Galopina; Leptostigma; Nenax; Nertera; Normandia; Opercularia; Phyllis; Pomax

Argostemmateae:* Argostemma; Cyaneuron; Mouretia; Mycetia

Paederieae:* Aitchisonia; Gaillonia; Jaubertia; Kelloggia; Leptodermis; Paederia; Plocama; Pseudopyxis; Putoria; Saprosma; Serissa; Spermadictyon

Theligoneae: Theligonum

Rubieae: Asperula; Crucianella; Cruciata; Galium; Rubia; Sherardia; Valantia

\section{SUBFAMILY IXOROIDEAE S.L.}

Condamineeae-Calycophylleae-Hippotideae-complex:* Alseis; Bathysa; Calycophyllum; Capirona; Chimarrhis; Condaminea; Dialypetalanthus; Dioicodendron; Dolichodelphys; Elaeagia; Emmenopterys; Ferdinandusa; Hippotis; Macrocnemum; Mastixiodendron; Parachimarrhis; Pentagonia; Picardaea; Pinckneya; Pogonopus; Rustia; Semaphyllanthe; Simira; Sommera; Tammsia; Tresanthera; Wittmackanthus

Note: The delimitation of the Condamineeae, Calycophylleae, and Hippotideae is highly problematic. Rova (1999) suggests that the Hippotideae and Calycophylleae might be monophyletic, but their relation with the other genera of the complex is unknown. Until more data become available, we prefer not to split the complex into smaller entities.

Mussaendeae: Aphaenandra; Heinsia; Landiopsis; Mussaenda; Neomussaenda; Pseudomussaenda; Schizomussaenda

Sabiceeae:* Ecpoma; Pseudosabicea; Sabicea; Stipularia

Virectarieae:* Hekistocarpa; Virectaria

Sipaneeae: Limnosipanea; Sipanea; Sipaneopsis

Henriquezieae** Gleasonia; Henriquezia; Platycarpum. Tentatively included: Molopanthera; Posoqueria.

Retiniphylleae: Retiniphyllum

Ixoreae: Captaincookia; Doricera; Ixora; Myonima; Versteegia. Tentatively included: Scyphiphora.

Vanguerieae: Ancyclanthos; Canthium; Cuviera; Fadogia; Fadogiella; Hutchinsonia; Keetia; Lagynias; Meyna; Multidentia; Pachystigma; Peponidium; Perakanthus; Psydrax; Pygmaeothamnus; Pyrostria; Rytigynia; Scyphochlamya; Tapiphyllum; Vangueria; Vangueriella; Vangueriopsis

Alberteae: Alberta; Nematostylis 
Coffeeae: Bertiera; Coffea; Diplospora; Discospermum; Psilanthus; Sericanthe; Tricalysia Octotropideae: Jovetia; Lamprothamnus; Octotropis; Paragenipa; Polysphaeria; Ramosmania Pavetteae: Cladoceras; Coleactina; Coptosperma; Dictyandra; Homollea; Homolliella; Leptactina; Nichallea; Pachystylus; Paracephaelis; Pavetta; Robbrechtia; Rutidea; Schizenterospermum; Tarenna; Tennantia

Gardenieae: Adenorandia; Aidia; Aidiopsis; Alibertia; Alleizettella; Amaioua; Atractocarpus; Atractogyne; Benkara; Borojoa; Brachytome; Brenania; Burchellia; Byrsophyllum; Calochone; Casasia; Catunaregam; Ceriscoides; Coddia; Deccania; Didymosalpinx; Dioecrescis; Duperrea; Duroia; Euclinia; Fagerlindia; Ganguelia; Gardenia; Genipa; Glossostipula; Himalrandia; Hyperacanthus; Kailarsenia; Kochummenia; Kutchubaea; Larsenaikia; Macrosphyra; Mantalania; Massularia; Melanopsidium; Mitriostigma; Monosalpinx; Morelia; Oligocodon; Oxyanthus; Oxyceros; Pelagodendron; Phellocalyx; Pleiocoryne; Porterandia; Preussiodora; Pseudomantalania; Randia; Riodocea; Rosenbergiodendron; Rothmannia; Rubovietnamia; Schumanniophyton; Sherbournia; Sphinctanthus; Stachyarrhena; Sukunia; Sulitia; Tamilnadia; Tarennoidea; Tocoyena; Trukia; Vidalasia. Tentatively included: Argocoffeopsis.

Note: Some general pollen comments on the tribe Gardenieae s.l. are given by Robbrecht and Puff (1986). The delimitation of several genera of the Gardenieae is still in state of flux. Because it is remarkably variable in the tribe, pollen should be investigated to help determine generic boundaries.

\section{SUBFAMILY CINCHONOIDEAE S.STR.}

Cinchoneae: Cinchona; Dolicholobium; Joosia; Ladenbergia; Remijia; Stilpnophyllum Isertieae: Isertia; Kerianthera; Raritebe; Schizostigma; Temnopteryx

PECC complex: Asemnantha; Badusa; Bikkia; Catesbaea; Ceratopyxis; Chiococca; Coutaportla; Coutarea; Erithalis; Exostema; Hintonia; Isidorea; Morierina; Nernstia; Osa; Portlandia; Salzmannia; Schmidtottia; Scolosanthus; Syringantha. Sister to PECC: Strumpfia. Pollen of this species differs from pollen of the PECC complex in the absence of supratectal elements.

Naucleeae (including Hymenodictyoneae): Adina; Adinauclea; Breonadia; Breonia; Burttdavya; Cephalanthus; Corynanthe; Cubanola; Gyrostipula; Haldina; Hallea; Hymenodictyon; Janotia; Ludekia; Metadina; Mitragyna; Myrmeconauclea; Nauclea; Neolamarckia; Neonauclea; Ochreinauclea; Paracorynanthe; Pausinystalia; Pertusadina; Sarcocephalus; Sinoadina; Uncaria

Hillieae/Hamelieae: Cosmibuena; Hamelia; Hillia; Hoffmannia. Tentatively included: Balmea; Chione.

Rondeletieae:* Blepharidium; Roigella; Rondeletia; Suberanthus. Tentatively included: Acunaeanthus; Glionnetia; Habroneuron; Rogiera (pro parte); Stevensia.

Guettardeae:* Arachnothryx; Chomelia; Gonzalagunia; Guettarda; Javorkaea; Timonius. Tentatively included: Dichilanthe.

\section{UNCERTAIN POSITION}

Genera incertae sedis: Acranthera; Airosperma; Aleisanthia; Aleisanthiopsis; Aoranthe; Aphanocarpus; Ariadne; Augusta; Calycosiphonia; Coryphothamnus; Crossopteryx; Dunnia; Greeniopsis; Jackiopsis; Kajewskiella; Lathraeocarpa; Lindenia; Mitchella; Mussaendopsis; Myrioneuron; Pagameopsis; Petitiocoden; Placocarpa; Sacosperma; Stephanococcus; Trailliaedoxa; Wendlandia 